UNIVERSIDADE DE SÃO PAULO

ESCOLA DE ENFERMAGEM DE RIBEIRÃO PRETO

LARA DE FARIA LANZA

\title{
Histórias de mulheres sobreviventes ao câncer de mama
}

RIBEIRÃO PRETO 


\title{
Histórias de mulheres sobreviventes ao câncer de mama
}

\author{
Tese apresentada à Escola de \\ Enfermagem de Ribeirão Preto, da \\ Universidade de São Paulopara obtenção \\ do título de Doutor em Ciências, \\ Programa de Pós-Graduação em \\ Enfermagem Psiquiátrica. \\ Linha de Pesquisa: Promoção de Saúde \\ Mental. \\ Orientador: Profa. Dra. Ana Maria \\ Pimenta Carvalho.
}


AUTORIZO A REPRODUÇÃO E DIVULGAÇÃO TOTAL OU PARCIAL DESTE TRABALHO, POR QUALQUER MEIO CONVENCIONAL OU ELETRÔNICO, PARA FINS DE ESTUDO E PESQUISA, DESDE QUE CITADA A FONTE.

FICHA CATALOGRÁFICA

Lanza, Lara de Faria

Histórias de mulheres sobreviventes ao câncer de mama.

Ribeirão Preto, 2012.

148p. : il.; $30 \mathrm{~cm}$.

Tese de Doutorado, apresentada à Escola de Enfermagem de Ribeirão Preto/USP. Área de concentração: Enfermagem Psiquiátrica.

Orientadora: Pimenta, Ana Maria Carvalho.

1. Câncer de mama. 2. Sobrevivência. 3. Identidade 


\section{FOLHA DE APROVAÇÃO}

LANZA, Lara de Faria.

Histórias de mulheres sobreviventes ao câncer de mama.

Tese apresentada à Escola de Enfermagem de Ribeirão Preto da Universidade de São Paulo para obtenção do título de Doutor em Ciências, Programa de Pós-Graduação em Enfermagem Psiquiátrica.

Aprovada em:

1

Banca Examinadora

Prof.Dr.

Instituição

Assinatura:

Prof.Dr.

Instituição

Assinatura:

Prof.Dr.

Instituição

Assinatura:

Prof.Dr.

Instituição

Assinatura:

Prof.Dr.

Instituição

Assinatura: 


\section{DEDICATÓRIA}

A todos que vívenciaram o câncer e, em especial, às mulheres sobreviventes que participaram deste estudo com suas histórias e que, sem estas, não sería possivel a reatização do mesmo.

Aos profissionais da área da saide que se doam ao trabalharem com pacientes oncológicos e familiares, e mudam, de alguma maneira, suas vidas. 
Aos meus pais, Célio e Fátima, pelo amor, apoio, confiança, companheirismo e respeito ao meu trabalho.

Ao mew fitho Luca que esteve comigo desde o inicio deste trabalho, iluminandoa minha vída.

Ao mew irmão Césare também aos mens padrinhos Sílvia e Ricardo sempre tão presentes.

A minha orientadoraAna Maria que com grande generosidade acothew-me, partithando comigo rico aprendizado nabusca pelos methores caminhos.

À Profa. Dra. Ana María Almeidae à Profa. Dra. Renatalabate pelas valiosas contribuiçóes, que muito me ajudaram no aperfeiçoamento deste trabalho.

À Profa. Dra.ElizabethRanier Martins do Valle que me incentivow ao inicio deste trabalho.

À equipe de profisisonais do Instituto Rübeirãopretano de combate ao Câncer.

Às mutheres que participaram desde estudo, por compartitharem suas histórias comigo.

À Escola de Enfermagem de Ribeirão Preto - USP, a qual proporcionow mew desenvolvimento enquanto pesquisadora.

À Coordenação de Aperfeiçoamento de Nível Superior (CAPES) pela concessão da bolsa de doutorado.

A todos que de alguma forma estiveram presentes nesta etapa. 
Felicidade (MarceloJeneci)

Haverá um dia em que você nã haverá de ser feliz.

Sem tirar $\sigma$ ar, semse mexer, sem desejar como antes sempre quis.

Você vaí rir, sem perceber, felicidade é só questão de ser.

Quando chover, deixar mothar pra receber o sol quando voltar.

Lembrará os dias que você deixou passar sem ver a luz.

Se chorar, chorar é vão porque os dias vão pra nunca mais.

Methor viver, meubem, pois há um lugar em que o sol britha pra você.

Chorar, sorrir tambéme depois dançar, na chuva quando a chuva vem.

Methor viver, meubem, pois há um lugar em que o sol britha pra você.

Chorar, sorrir também e dançar.

Dançar na chuva quando a chuva vem.

Tem vez que as coisas pesam mais do que a gente acha que pode aguentar.

Nessa hora fique firme, pois tudo isso logo vai passar.

Você vaí rir, sem perceber, felicidade é só questão de ser.

Quando chover, deixar mothar pra receber o sol quando voltar.

Methor viver, meubem, pois há um lugar em que o sol britha pra você.

Chorar, sorrir tambéme depois dançar, na chuva quando a chuva vem.

Methor viver, meubem, pois há um lugar em que o sol britha pra você.

Chorar, sorrír tambéme dançar.

Dançar na chuva quando a chuva vem. 


\section{RESUMO}

Lanza, L.F. Histórias de mulheres sobreviventes ao câncer de mama. 2012. 148 f. Tese (Doutorado) - Escola de Enfermagem de Ribeirão Preto, Universidade de São Paulo, Ribeirão Preto, 2012.

Os cânceres ou neoplasias malignas vêm assumindo um lugar cada vez mais importante entre as doenças que acometem a população feminina, representando no Brasil e no mundo, importante causa de morte. O câncer de mama é o segundo tipo de câncer mais freqüente no mundo e o primeiro entre as mulheres. Os avanços da medicina, possibilitando tratamentos mais eficientes e técnicas que viabilizam a detecção precoce, têm contribuído para o aumento da sobrevida das mulheres com câncer de mama.Tendo em vista a alta incidência do câncer de mama eo aumento da sobrevida, faz-se cada vez mais necessário compreender a realidade destas mulheres que experienciam o adoecimento e a sobrevivência a ele. Este trabalho teve como objetivo compreender a experiência de sobreviver ao câncer de mama a partir de elementos presentes nas histórias de mulheres sobreviventes. $O$ estudo é de natureza qualitativa, realizado com 15 mulheres sobreviventes de câncer de mama, que haviam concluído o tratamento há no mínimo cinco anos. A técnica utilizada para coleta de dados foi a entrevista narrativa e a análise foi feita com base nos estudos de Little et al. (2002) e Frank (2012). Os dados foram organizados em torno de três momentos principais: o início da história - o diagnóstico; o enfrentamento - tratamento; e o desfecho - retomando a vida, buscando compreender o sentido que cada participante atribuía a sua história enquanto uma pessoa que passou pelo tratamento do câncer e sobreviveu. Foi percebido que muitas mulheres tiveram sua identidade mudada após a experiência do adoecimento e a maioria delas conseguiu retomar sua vida a uma condição semelhante à anterior à doença. Assim os resultados revelam a singularidade e diversidade no modo de experienciar o adoecimento e a sobrevivência e as repercussões desta experiência na identidade da mulher.

Palavras-chave: Câncer de mama, sobrevivência, identidade. 


\begin{abstract}
Lanza, L.F. Stories of womensurviving breast cancer.2012. 148 p.Thesis (Doctorate) - NursingSchoolof Ribeirão Preto, Universityof São Paulo, Ribeirão Preto, 2012.
\end{abstract}

Cancers or malignant neoplasias have been reported as important diseases among women, representing causes of death not only in Brazil but in the whole world. Breast cancer is the second most frequent type of cancer worldwide and the first among women. Medical advancements have improved the survival rates for women with breast cancer through more efficient treatments and techniques. Considering the high incidence of breast cancer and the increase of survival rates, the understanding of these women's realities - being sick and recovering from it - has become extremely important. The objective of this study was to understand the experiences of surviving breast cancer from elements present in the stories of women survivors. The study is qualitative - 15 surviving breast cancer women were studied and their treatments had been finished 5 years earlier at least. The technique used to collect data was through interviews and the analysis was done based in the studies of Little et al. (2002) and Frank (2012). The data was organised considering 3 main moments: the beginning of the disease (medical diagnosis); the confrontation (treatment); and the end (regaining life). The main objective was to understand the meaning each woman gave to her experience after having survived. Many women have had their identities changed after the disease and most of them have managed to regain their lives. Thus, the results show the singularity and the diversity in experiencing getting sick and surviving and the effects of these experiences in women's identities.

Key-words: Breast cancer, survival, identity. 


\section{RESUMEN}

Lanza, L.F. Historias de mujeres sobrevivientes al Cáncer de Mama. 2012. 148 f. Tesis (Doctorado) - Escuela de Enfermería de Ribeirao Preto, Universidad de Sao Paulo, RibeiraoPreto, 2012.

Los cánceres o neoplasias malignas vienen asumiendo un lugar cada vez más importante entre las enfermedades que afectan a la población femenina, representando una importante causa de muerte, tanto en Brasil como en el mundo. El cáncer de mama es el segundo tipo de cáncer más frecuente en el mundo, y el primero entre las mujeres. Los avances de la medicina han contribuido al aumento de la supervivencia de las mujeres con cáncer de mama, hecho que permite contar con tratamientos más eficaces y técnicas que posibilitan la detección precoz de la enfermedad. Dada la alta incidencia del cáncer de mama y el aumento de la sobrevivencia, se hace cada vez más necesario comprender la realidad de estas mujeres que viven la experiencia de sufrir dicha enfermedad y de sobrevivir a ella. Este trabajo tuvo como objetivo comprender la experiencia de sobrevivir el cáncer de mama a partir de elementos presentes en las historias de mujeres supervivientes. El estudio es de naturaleza cualitativa, realizado con 15 mujeres sobrevivientes al cáncer de mama, que habían concluido el tratamiento hacía cinco años atrás como mínimo. La técnica utilizada para la recolección de datos fue la entrevista narrativa, y el análisis fue hecho en base a los estudios de Little et al. (2002) y Frank (2012). Los datos fueron organizados en torno a tres etapas principales: el inicio de la historia (el diagnóstico), el enfrentamiento (el tratamiento), y el resultado (retomando la vida), y persiguió comprender el sentido que cada participante atribuía a su propia historia desde la perspectiva de una persona que se sometió a un tratamiento de cáncer y consiguió sobrevivir. Fue percibido que muchas mujeres tuvieron su identidad transformada después de la experiencia de la enfermedad, y la mayoría de ellas consiguió recobrar su vida con una condición semejante a la que tenían anteriormente a la dolencia. De tal forma, los resultados revelan la singularidad y diversidad en la manera de experimentar la enfermedad y la sobrevivencia, y las repercusiones de dicha experiencia en la identidad de la mujer.

Palabras-clave: Cáncer de Mama, sobrevivencia, identidad. 


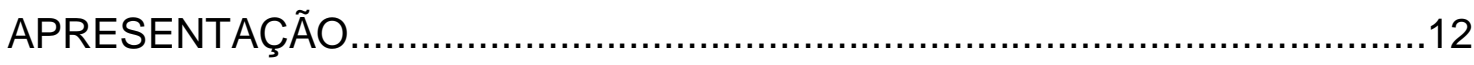

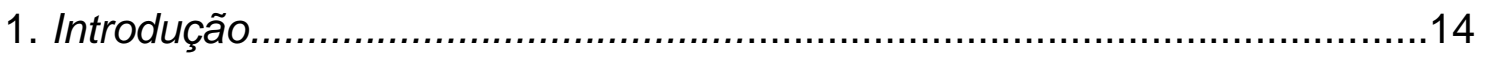

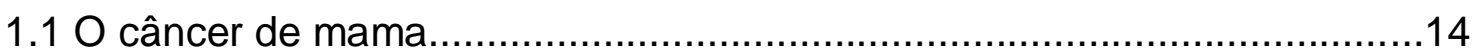

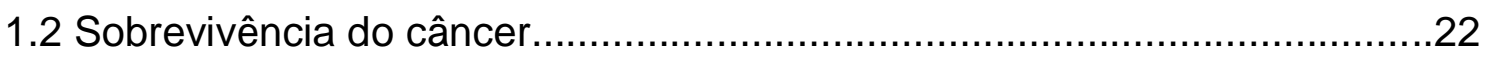

2. Elementos teóricos e metodológicos do estudo..........................................29

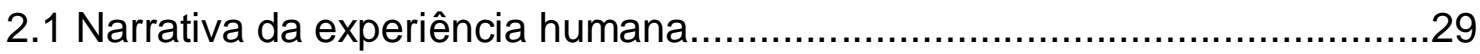

2.2 Narrativa no contexto da saúde/doença..................................................33

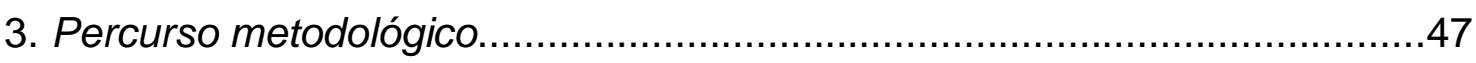

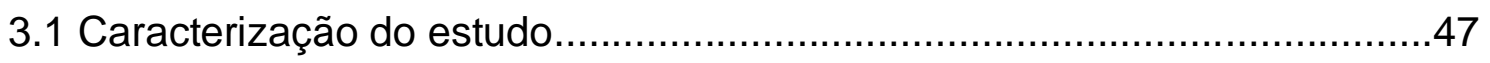

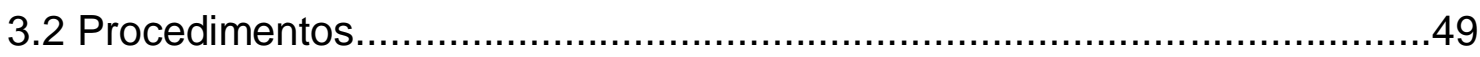

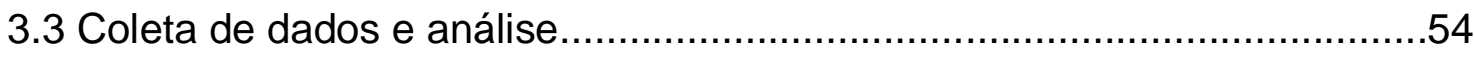

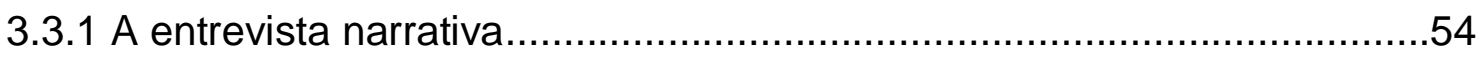

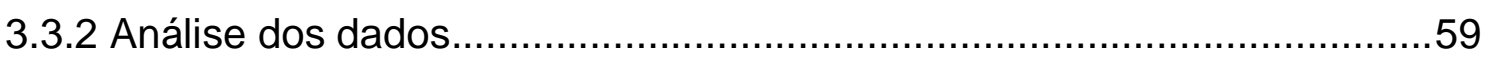

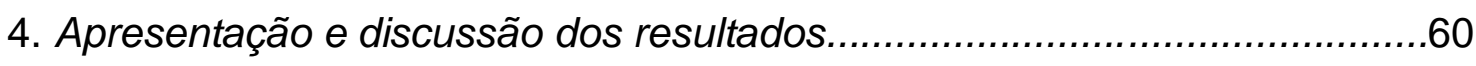

4.1. Identificação das participantes.............................................................6

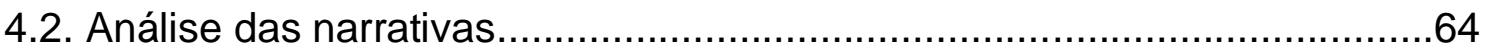

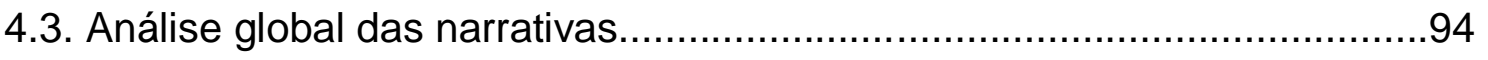

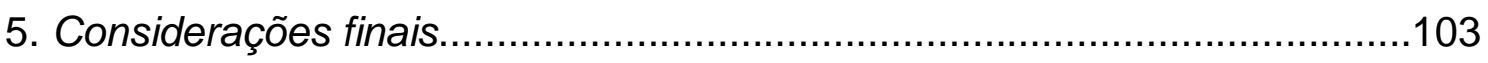

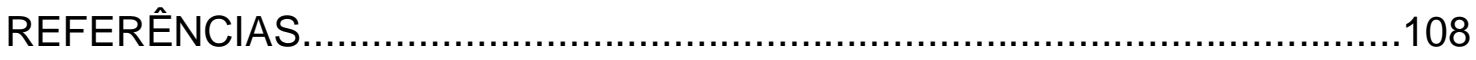

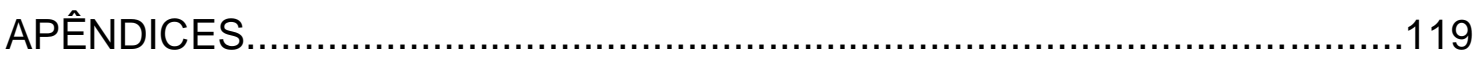

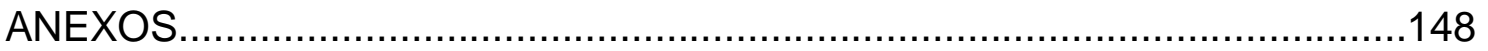


Apresentação

Dedicar alguns anos da vida a uma atividade de pós-graduação, em nível de doutorado, é, sem dúvida, no mínimo, uma grande responsabilidade. Filha de pais muito amorosos, mas não menos exigentes, os quais sempre proporcionaram o melhor para minha formação pessoal e profissional, tive sempre muita liberdade de escolha, saindo de uma cidade pequena, para morar em Campinas aos 17 anos. Aproveitei as festas, a experiência de morar com amigas, aprendi a me virar sozinha e o maior acerto, me tornei psicóloga. Um mundo se abria diante de mim... Decidi aprimorar-me em psicologia clínica e hospitalar, tendo trabalhado por vários anos com atendimentos clínicos, depois tive a oportunidade de atuar como docente em outra universidade e também com orientação psicológica na área escolar. Com certo caminho percorrido e alguns questionamentos sobre o que realmente fazia sentido para mim, percebi que a área que mais me encantava era a área da saúde. Despertou-me então, o desejo por desenvolver um estudo relacionado à oncologia, tema o qual sempre tive muito interesse. Em meu mestrado estive com crianças que estavam finalizando o tratamento do câncer, buscando compreender suas expectativas futuras, sendo esta uma experiência bastante enriquecedora. Ao final mestrado surgiram novas inquietações e o desejo de seguir em oncologia. Fazer um doutorado significou maturidade, exigiu comprometimento, aceitação de exigências e muita dedicação.

Entre dúvidas sobre estar ou não no caminho certo, em movimentos de perder-me e encontrar-me, ouvi sábias palavras sobre não existir o caminho 
certo, e sim, o melhor caminho, e o melhor caminho é aquele que faz sentido para a própria pessoa. Era o que eu precisava ouvir para continuar...

Estar com pessoas que enfrentam o adoecimento por câncer, pode parecer, para muitos, assustador. Para mim, estar com estas pessoas trouxe um novo modo de olhar a vida, um novo modo de enxergar as pessoas, um novo modo de sentir. Foi um presente estar com mulheres sobreviventes ao câncer de mama e poder ouvir suas histórias, possibilitando-me a percepção de que a vida não está entre o adoecimento e a saúde, a vida vai além, ela é feita de histórias... Experiências... Significados...

Trabalhar com a temática do câncer tem sido desafiador, é como buscar compreender um mundo que não Ihe pertence, não lhe pertence até 0 momento em que você se dispõe a estar junto com a pessoa que vivencia esta experiência e compartilha a sua história. Então, posso dizer, não há mais como ser como era, um novo mundo se apresenta. 


\section{Introdução}

\subsection{Câncer de mama}

Os cânceres ou neoplasias malignas vêm assumindo um papel cada vez mais importante entre as doenças que acometem a população feminina, representando no Brasil e no mundo, importante causa de morte. O câncer de mama é o segundo tipo de câncer mais freqüente no mundo e o primeiro entre as mulheres. No Brasil, é a primeira causa de morte por câncer na população feminina, principalmente na faixa etária entre 40 e 69 anos (BRASIL, 2010).

Estatísticas indicam que, a cada ano, cerca de $22 \%$ dos novos casos de câncer em mulheres são de mama. $O$ aumento em sua freqüência acontece tanto nos países desenvolvidos quanto naqueles em desenvolvimento, sendo que em alguns países desenvolvidos, como é o caso dos Estados Unidos, Canadá, Reino Unido, Holanda, Dinamarca e Noruega, o aumento da incidência é acompanhado de uma redução da mortalidade por esse câncer, o que está associado à detecção precoce por meio da introdução da mamografia para rastreamento e à oferta de tratamento adequado; enquanto que em outros países, como no caso do Brasil, o aumento da incidência tem sido acompanhado do aumento da mortalidade, o que pode ser atribuído, principalmente, a um retardamento no diagnóstico e na instituição de terapêutica adequada (BRASIL, 2010).

Alguns aspectos relativos à vida reprodutiva da mulher (menarca precoce, nuliparidade, idade da primeira gestação a termo acima dos 30 anos, anticoncepcionais orais, menopausa tardia e terapia de reposição hormonal) 
estão estabelecidos como fatores de risco em relação ao desenvolvimento do câncer de mama. A idade continua sendo um dos mais importantes fatores de risco. As taxas de incidência aumentam rapidamente até os 50 anos, e é relativamente raro antes dos 35 anos de idade. Fatores genéticos também estão associados ao maior risco de desenvolvimento de câncer de mama. A amamentação, prática de atividades físicas e alimentação saudável com a manutenção do peso corporal estão associadas a um menor risco de desenvolver esse tipo de câncer (BRASIL, 2010).

O câncer de mama é considerado de bom prognóstico se diagnosticado e tratado precocemente, sendo o principal fator que dificulta 0 tratamento 0 estágio avançado em que a doença geralmente é descoberta. Em nosso país a maioria dos casos é diagnosticada em estágios avançados, correspondendo a cerca de $60 \%$ dos diagnósticos; por isso o número de mastectomias realizadas no Brasil é considerado alto (MAKLUF; DIAS; BARRA, 2006). Em tais condições observa-se uma diminuição das chances de sobrevida, comprometimento dos resultados do tratamento e, consequentemente, perdas na qualidade de vida das pacientes (BRASIL, 2010; THULER; MENDONÇA, 2005).

Os avanços na medicina com relação ao tratamento do câncer envolvendo cirurgia (mastectomia parcial ou radical), quimioterapia, radioterapia e hormonioterapia, e nas técnicas que viabilizam a detecção precoce têm melhorado as taxas de sobrevida, possibilitando aos pacientes a convivência com uma doença crônica sem perda da qualidade de vida (GIANINI, 2007). Apesar dos avanços no diagnóstico e tratamento terem permitido um aumento considerável de sobreviventes, o câncer ainda é uma 
doença que continua associada a uma representação social negativa (POWE; FINNIE, 2003) tendo adquirido, em nossa sociedade, significados relacionados à culpa, punição, deterioração, dor e morte (SILVA, 2008).

Uma desestruturação e alterações significativas ocorrem nas diversas esferas da vida da mulher que experimenta o diagnóstico e o tratamento do câncer de mama e de seus familiares. Além dos efeitos físicos, o câncer de mama pode comprometer em vários graus a autoestima, a imagem corporal e a identidade das mulheres (BLOOM, 2002; SALES et al. 2001; SILVA, 2008; VENÂNCIO, 2005). Também se mostram presentes preocupações como 0 temor de ter uma doença em que nem sempre é possível alcançar a cura, repleta de sofrimentos e estigma, questões relacionadas à feminilidade, maternidade e sexualidade (VENÂNCIO, 2005), alterações na autoimagem, perda funcional, alterações psíquicas, emocionais e sociais (MAKLUF; DIAS; BARRA, 2006).

As reações das mulheres frente à doença, ao tratamento e à reabilitação dependem de características individuais, tais como: história de vida, contexto cultural e social (ASHING et. al, 2003), espiritualidade e opção sexual e diferem nas diversas etapas do tratamento (BLOOM, 2002; FROST et al., 2000; GIMENES, 1997). Essas características também irão influenciar a forma de avaliar a importância da doença e de enfrentá-la (FOBAIR et al. 2001; GIMENES, 1997).

Estudo realizado por Vieira, Lopes e Shimo (2007) retrata o modo particular como cada mulher vivencia o câncer de mama e os sentimentos relacionados a essa experiência. Apesar do âmbito particular, os autores 
concluem que existem alguns sentimentos apresentados de modo universal, sendo comuns a diversas mulheres acometidas pelo câncer de mama.

Em seu livro Pollin (1995) descreve oito preocupações constantes na vida de pacientes que vivenciam doenças crônicas, estando diretamente relacionadas ao diagnóstico de câncer de mama: perda do controle sobre a vida, mudanças na autoimagem, medo da dependência, estigmas, medo do abandono, raiva, isolamento e morte. O medo da progressão da doença e da recidiva são outras preocupações constantes e comumente verbalizadas (BERGAMASCO; ANGELO, 2001).

Bergamasco e Angelo (2001) avaliaram o impacto psicossocial que o câncer de mama teve na vida das mulheres e de seus familiares. De acordo com estes autores, essas mulheres experimentaram preconceitos, medo da morte, sofrimento relacionado à mutilação, receio do surgimento do linfedema e, até mesmo, sentimentos de desvalorização social.

Outro estudo buscou verificar as repercussões psicossociais do diagnóstico de câncer de mama e do tratamento médico, bem como identificar o apoio social e o bem-estar espiritual. Foi verificado que, frente ao diagnóstico, as mulheres manifestaram diversas reações emocionais, tanto sentimentos negativos - tristeza, raiva e medo $(82,7 \%)$, quanto sentimentos positivos esperança, tranquilidade, confiança (10,7\%). Sobre as fontes de apoio, verificou-se que as participantes do estudo perceberam maior apoio da família (parentes próximos), dos companheiros e dos amigos (HOFFMANN; MULLER; FRASSON, 2006). Esses achados corroboram com estudos relacionados, nos quais os parentes próximos são referidos em primeiro lugar (KORNBLITH et al, 2001; VIGO; CARN, 2002; WALSH, 2005), demonstrando que o apoio está 
fundamentalmente baseado na família de origem. Com relação ao bem-estar espiritual, a religião foi vista como complementar ao apoio recebido.

Com o intuito de compreender o papel da espiritualidade e da religião no enfrentamento da doença foram realizados estudos com mulheres diagnosticadas com câncer de mama, evidenciando a importância da crença e da fé espiritual na recuperação, sendo a espiritualidade e a religião utilizadas como recursos, manifestando-se pela prece, dependendo de Deus para interceder e guiar os pensamentos sobre a doença ou buscando suporte social de pessoas da comunidade religiosa. Esses achados vêm a fundamentar uma ênfase crescente na religião e na espiritualidade a partir da vivência do câncer (BOWIE et al., 2001; CHOUMANOVA et al., 2006; MANNING-WALSH, 2005).

Objetivando investigar as repercussões psicológicas associadas ao adoecer em mulheres com câncer de mama submetidas à mastectomia (total ou parcial), radioterapia e quimioterapia, Rossi e Santos (2003) identificaram, por meio de um estudo, quatro momentos fundamentais vivenciados, desde 0 aparecimento dos primeiros sintomas do câncer de mama até a finalização do tratamento e o início do processo de reabilitação. As repercussões psicológicas encontradas são peculiares a cada um dos quatro momentos: momento prédiagnóstico, etapa do diagnóstico, etapa do tratamento e momento póstratamento. No momento pré-diagnóstico, evidenciou-se o descuido das pacientes com relação ao próprio corpo, a postergação da consulta médica e a negação da realidade que só foi desvelada com o diagnóstico posteriormente. $\mathrm{Na}$ etapa do diagnóstico as pacientes formularam suas queixas quanto à postura negligente dos profissionais médicos e enfatizam os sentimentos vivenciados com relação à doença e ao tratamento: impacto inicial (reação de 
choque), vislumbre da morte, temores relacionados ao possível desamparo dos filhos, dentre outros. Na etapa do tratamento, a queixa das pacientes compreenderam os efeitos físicos e os danos causados ao organismo pelo tratamento cirúrgico, rádio e quimoterápico, bem como os sentimentos com relação a alterações da imagem corporal. No momento pós-tratamento, apareceram as repercussões no plano afetivossexual e também as dificuldades de adaptação à nova situação de vida, com limitações físicas e restrições, embora também fossem reconhecidas as mudanças positivas trazidas pela experiência de terem passado pelo câncer de mama e seu tratamento.

Alguns estudos apontaram que a primeira preocupação da mulher após receber o diagnóstico de câncer de mama é a sobrevivência. Em seguida surge a preocupação com o tratamento e condições econômicas para realizá-lo; e quando o tratamento está em andamento, as inquietações se voltam para a mutilação, a desfiguração e suas conseqüências para a vida sexual da mulher (DUARTE; ANDRADE, 2003; GIMENES; QUEIROZ, 2000). Duarte e Andrade (2003) perceberam, por meio de um estudo com mulheres mastectomizadas, o qual tinha por objetivo compreender como estas percebem a sua própria sexualidade, a importância de dois momentos considerados marcantes. $O$ primeiro momento foi caracterizado pela descoberta do câncer, em que a mulheres passaram a conviver com a possibilidade de morte, e o segundo momento envolveu o período pós-cirúrgico e, finalmente foram expressas tentativas de retomar o cotidiano. $O$ estudo mostrou as dificuldades encontradas pela mulher para se adequar a uma nova situação, a perda da mama, que compromete de certa forma todos os âmbitos de sua vida. Segundo 
as autoras, o processo de (re) adequação da sexualidade a essa novo referencial de corpo ocorre lentamente.

Estudos prospectivos avaliando a qualidade de vida de mulheres submetidas à mastectomia demonstraram agravamento não só na imagem corporal, mas também na vida sexual, limitações no trabalho e até mesmo mudanças nos hábitos e atividades diárias (ENGEL et al., 2004; GANZ et al., 2004). A diminuição do interesse sexual é causada pelos efeitos secundários do tratamento, como menopausa precoce, diminuição da libido e alteração na produção de hormônios sexuais, o que torna o ato sexual doloroso, além de diminuir a excitação e inibir o orgasmo (ALMEIDA et al., 2001). A redução da qualidade de vida nos domínios emocional, social e sexual permanece não somente no período de um a dois anos após o tratamento inicial, mas também após cinco anos, confirmando a necessidade de um acompanhamento psicológico mesmo após o término do tratamento clínico (HOLZNER et al., 2001).

A atuação interdisciplinar para a prevenção de complicações decorrentes do tratamento deve ser realizada em todas as fases: diagnóstico; durante e após o tratamento; na recorrência da doença e nos cuidados paliativos, junto aos pacientes e familiares. Em cada uma dessas fases, é necessário conhecer e identificar as necessidades da mulher, os sintomas e suas causas, e o impacto destes em seu cotidiano.

Um tratamento de alta qualidade pode produzir uma taxa de sobrevida de cinco anos em $75 \%$ ou mais em certos tipos de câncer, como câncer de mama, câncer de cólo uterino, colorretal, testículo e melanoma (WORLD HEALTH ORGANIZATION (WHO), 2010). 
No final da década de 70 do século passado começaram as discussões sobre os efeitos secundários do câncer e seu tratamento, assim como a toxicidade da terapia e o impacto na qualidade de vida dos sobreviventes, que passaram a fazer parte dos cuidados de acompanhamento em oncologia, considerando-se o número crescente de sobreviventes (JEMAL et al., 2009; MASTELLARO et al., 2004).

Bottomley e Kassner (2003) relatam, em um de seus estudos, sobre a importância dos profissionais de saúde estar atentos aos possíveis efeitos tardios do tratamento, na assistência ao sobrevivente de câncer, procurando manter uma apropriada avaliação médica e psicossocial. De acordo com estes autores, a orientação aos sobreviventes com relação aos riscos de efeitos tardios da doença e do tratamento é fundamental, devendo ser estimulados a desenvolver e manter comportamentos e estilos de vida saudáveis e a participar de programas de acompanhamento médico, alcançando melhorias ao longo do tempo e buscando uma melhor qualidade de vida.

O tratamento do câncer visa a cura, prolongar a vida e melhorar a qualidade de vida dos pacientes. É um processo gradual, que exige atenção constante e cuidados permanentes e que, cada pessoa tem seu jeito particular de sair do processo (MENEZES et al., 2007). Diversos avanços tecnológicos na área da saúde ocorridos nos últimos anos têm contribuído para o aumento da sobrevivência e a melhoria da qualidade de vida do paciente com câncer, além da redução do impacto emocional por ele sofrido (LIBERATO; MACIEIRA, 2008). 
O câncer muitas vezes é visto como um divisor de águas, existindo, portanto, uma percepção da vida antes da doença e outra, bem distinta, depois da doença (MENEZES et al., 2007).

Tendo em vista a alta incidência do câncer de mama, a grande possibilidade de uma longa sobrevida e a desestruturação que o diagnóstico e tratamento acarretam na vida da mulher, faz-se cada vez mais necessário um acompanhamento qualificado a estas pacientes (BLOOM, 2002; SALES et al., 2001).

1.2 Sobrevivência do câncer

No século XIX e primeiras décadas do século XX, o câncer era considerado contagioso e associado à falta de limpeza, à sujeira física e moral. Além disso, concebia-se que a doença poderia ser contagiosa entre os amantes dos excessos do prazer, principalmente no caso das mulheres, nas quais o adoecimento era resultado de "pecados e vícios", em especial nas práticas sexuais. Durante os anos 30 e 40, a argumentação de cunho moral continua em evidência, porém mesclando-se a outros fatores tais como a ingestão de alimentos com produtos químicos, o hábito de fumar, o excesso de trabalho e o aumento de preocupações cotidianas (SANT'ANNA, 2000).

A partir de 1950 ocorreram grandes avanços nos métodos de rastreio e detecção precoce e tratamento, possibilitando o aumento no número de sobreviventes e no tempo de sobrevida, assim como melhores cuidados de suporte àqueles que conseguem sobreviver. $\mathrm{O}$ câncer, antes uma doença quase que uniformemente fatal, transformou-se em uma doença curável em 
muitos casos. Nos anos 60 e 70 os aspectos psicológicos passaram a ganhar mais atenção; lutar contra o câncer, nesse momento, implicava em autoconhecer-se, conhecer o próprio corpo e principalmente, requeria que 0 doente falasse abertamente sobre suas dificuldades emocionais, expusesse sua vida e doença e procurasse meios de fortalecimento e crescimento através da própria doença. Neste sentido, a partir da década de 1970 as experiências de mulheres com câncer ganharam destaque na literatura na forma de publicações de auto-ajuda e biografias, com o objetivo de tornar o câncer de mama, o tratamento e o processo de cura em experiências que, apesar da dor e sofrimento, pudessem ser revertidas em benefício da própria mulher (SANT'ANNA, 2000). As experiências das pessoas que vivenciaram o processo de sobreviver ao câncer também possibilitaram uma melhor compreensão para o cuidado em oncologia, que vai além do cuidado médico, entendendo os desafios sociais, e efeitos a longo prazo após a doença (HOWLAND, 2008; VANCHON, 2001).

O termo "sobrevivente" apareceu na década de 1970, desde então, novas definições vêm surgindo ao longo dos anos, não havendo consenso na literatura oncológica sobre a definição de sobrevivente (LANGEVELD et al., 2002). Em alguns contextos, como em catástrofes naturais, o termo sobrevivente pode implicar que o perigo passou. No entanto, para aqueles que tiveram câncer e passaram por longos tratamentos, o medo da recorrência muitas vezes continua a fazer parte de sua vida (PARK; ZLATEVA; BLANK, 2009). 
Nos últimos anos a identidade de "sobrevivente" tem sido muito utilizada para representar as pessoas que continuam a viver após o diagnóstico de câncer, independente de quanto tempo seja essa sobrevida. Profissionais da saúde, pesquisadores e aqueles que estão se recuperando de câncer tem discutido sobre sobrevivência, compreendendo não apenas o impacto físico do câncer, mas também social, psicológico, espiritual e existencial (TWOMBLY, 2004).

Mullan, um médico e sobrevivente do próprio câncer, escreveu em 1985 um artigo objetivando definir o curso do câncer. Neste artigo ele propõe o uso do termo "sobrevivência", que segundo ele, poderia ser aplicado tanto àqueles que estavam "curados", como aos que continuavam doentes; afirmando que existem muitos problemas residuais semelhantes em pessoas que tiveram vários tipos de câncer, independente de serem considerados curados ou não (FEUERSTEIN, 2007).

Atualmente, podemos encontrar algumas definições mais cabíveis, compreendendo por sobreviventes aqueles que estão livres dos sintomas da doença há pelo menos cinco anos, ou ainda aqueles que encerraram o tratamento há pelo menos dois anos (LANGEVELD et al., 2002). Outra referência designa como sobrevivente a pessoa que foi diagnosticada com câncer, e que já terminou os tratamentos previstos (FEUERSTEIN, 2007).

Adotamos, no presente estudo, a definição de sobrevivente a pessoa que está livre dos sintomas da doença há pelo menos cinco anos.

Ser sobrevivente significa viver com o câncer e apesar dele, e também viver com os efeitos colaterais e sequelas decorrentes das terapêuticas utilizadas para o seu controle (REUBEN, 2004). É uma saga que começa 
quando a pessoa recebe o diagnóstico de câncer, e continua para toda a vida. É a experiência de viver com, por ou além do câncer (MULLAN, 2001).

Essa experiência de ser sobrevivente só é vivida em toda a sua complexidade pela própria pessoa que a ela é submetida. O sobrevivente pode estar livre da doença, viver com doença crônica ou recorrente, estar em sofrimento físico ou psicológico em decorrência do tratamento, mas ainda assim é um sobrevivente. O fim do tratamento do câncer não quer dizer o fim da experiência de ter câncer. Assim sendo, a vida cotidiana com a segurança de outrora, a partir do câncer, é substituída pelo medo e a incerteza do amanhã. Surge a necessidade de o indivíduo dar sentido a essa experiência e elaborar formas para lidar com a sua nova condição, e continuar a viver (MUNIZ; ZAGO; SCHWARTZ, 2009).

O sentido da experiência dependerá da relação da pessoa com seu meio social. Assim, a doença poderá ter sentido destrutivo quando provocar a interrupção da atividade, perdas diversas em suas capacidades e em seus papéis sociais; como também pode ser vivenciada como libertadora, uma vez que torna possível à pessoa encontrar o verdadeiro sentido da vida, numa condição que se apresenta como de revelação ou mesmo de descoberta do self (MUNIZ; ZAGO; SCHWARTZ, 2009).

A experiência do término do tratamento também está diretamente relacionada ao modo de enfrentamento e adaptação do paciente e dos familiares que conviveram com a doença e o tratamento, e na maneira como procuraram resgatar sua rotina e planejaram o futuro (ANDERS; SOUZA, 2009; ORTIZ; LIMA, 2007). 
Há poucas décadas o câncer enquanto doença era um tópico envolto em silêncio social. Atualmente, histórias de adoecimento por câncer têm encontrado lugar em nossa cultura. $\mathrm{O}$ aparecimento desse discurso significa que aqueles que se tornaram doentes com câncer podem esperar certo grau de aceitação e compreensão, mas o mesmo não pode ser dito, todavia, de todos aqueles que sobrevivem ao câncer. Apesar do interesse que normalmente é gerado por histórias de sobrevivência, ainda existem tensões não resolvidas por aqueles que têm vivido para além da fase aguda da doença.

Acredita-se que a experiência de sobreviver ao câncer possa ser melhor compreendida por meio da avaliação das formulações sobre a identidade pessoal que aparecem em narrativas de sobreviventes que vivenciaram 0 câncer (LITTLE et al.,2002). Frank (1995) compreende o adoecimento como um evento particularmente propício a comportar discursos de mudança pessoal ou mudanças no self.

Muitas vezes as noções de ter vencido o câncer e de que ele pode voltar a qualquer momento são apresentadas de maneira contraditória. Em seu estudo com mulheres que tiveram câncer de mama, Kaiser (2008) percebeu as diferentes formas de lidar com a questão da sobrevivência. Neste estudo, algumas mulheres se mostraram capazes de se identificar como sobreviventes, mas também acreditavam que o câncer poderia estar à espreita atrás de cada dor ou alteração fisiológica, enquanto outras não se viam como sobreviventes, acreditando ser a sobrevivência incongruente à incerteza que sentiam de estarem livres ou não da doença. 
Muniz, Zago e Schwartz (2009) estudaram pacientes, de ambos os sexos, que experimentaram o câncer e passaram pelo tratamento radioterápico, observando um ajustamento destes pacientes à nova vida, e o surgimento de uma nova identidade, a de sobrevivente ao câncer. Com essa nova identidade, tentam retomar as atividades diárias e, planejam o futuro com esperança, apesar de uma sombra de incerteza quanto a estarem curados. $O$ fato de passarem pela fatalidade de ter câncer e submeterem-se à radioterapia possibilita compreender o quanto estas pessoas sentem os limites existenciais, incorporam a doença e o tratamento em suas vidas, inserindo-os num processo de incertezas que persiste para o resto da vida.

O estudo de Park, Zlateva e Blank (2009) objetivou compreender a aceitação e a rejeição dos termos sobrevivente, vítima, paciente e pessoa com câncer em pessoas que haviam vivenciado o câncer. Dos participantes, 83\% endossaram a identidade de sobrevivente, enquanto apenas 18\% como vítima. Estes resultados sugerem que diferentes identidades adotadas estão relacionadas a diversos fatores psicológicos, sendo que a maioria dos sobreviventes reconheceu diferentes identidades como partes de sua experiência. Segundo os autores, compreender quais rótulos ou identidades são mais confortáveis ou úteis para um paciente pode ajudar na adequação do atendimento e pode permitir que esses pacientes incorporem sua experiência com o câncer em um contexto mais amplo.

Concordamos com Silva e Trentini (2002) quando estes referem que ao conhecer como são as ações das pessoas quando estão vivenciando determinadas situações, os profissionais de saúde podem antecipar alguns 
cuidados, ter participação ativa e adequada, além de poder intervir caso haja algum risco.

Dada a importância do acompanhamento a pacientes que tiveram câncer, surpreendentemente há poucos trabalhos retratando a identidade e varáveis associadas após a doença. Partindo do pressuposto de que a mulher que concluiu o tratamento do câncer de mama e está sem os sintomas da doença por um período mínimo de cinco anos é uma sobrevivente, reconhecemos que ainda é pouco enfatizado o suporte a essa clientela. A partir deste princípio, afirmamos que enriquecer a compreensão acerca dos aspectos envolvidos na sobrevivência do câncer de mama contribui para que os profissionais de saúde, principalmente os de saúde mental, possam prestar assistência de maneira mais eficiente e abrangente.

Este estudo busca compreender a experiência de sobreviver ao câncer de mama a partir dos elementos presentes nas histórias/narrativas de mulheres sobreviventes. 


\section{Elementos teóricos e metodológicos do estudo}

2.1 Narrativa da experiência humana

Nosso primeiro encontro com as histórias acontece, na maioria das vezes, na infância, por meio de contos de fadas, contos populares e histórias familiares. Histórias continuam a absorver-nos durante toda a vida, como romances, biografias e outras histórias, e estão presentes nos filmes, teatros e na televisão. Possivelmente por causa dessa longa convivência, as histórias também sirvam como um meio pelo qual nos tornamos inteligíveis dentro do mundo social. Contamos histórias sobre nossa infância, nossas relações com os membros da família, nossos anos na escola, nosso primeiro amor, nossa reflexão sobre determinado assunto, e assim por diante (GERGEN, 1997).

Tão prevalente é o processo da história na cultura ocidental que, segundo Bruner (1986) há uma propensão genética para a compreensão narrativa. Preparados biologicamente ou não, não podemos subestimar a importância das histórias em nossas vidas, no entanto, dizer que utilizamos histórias para fazer-nos compreensíveis não é o bastante. Não só contamos nossas vidas como histórias, mas há também um sentido significativo no qual nossas relações uns com os outros são vividas de forma narrativa.

Gergen (1997) refere que vidas são eventos narrativos e histórias são, portanto, as formas de contá-las. Por meio de relatos narrativos, embebidos na ação social, tornamos eventos socialmente visíveis e tipicamente estabelecemos expectativas de eventos futuros. Os acontecimentos da vida diária estão imersos na narrativa e, portanto, carregados de um sentido de 
história. Em um sentido significativo, então, vivemos por meio de histórias tanto na narração quanto na realização de nossas próprias ações.

Gergen (1997) em seu estudo propõe a análise das formas da narrativa e das estruturas narrativas. Ele considera que as narrativas de si (self) não são fundamentalmente as posses do indivíduo, mas bens de relacionamento, e que um self com um passado e um futuro, não é um agente independente, único e autônomo, e sim, um self que existe imerso na interdependência. Portanto, para compreender uma ação é sempre necessário colocá-la em um contexto de acontecimentos anteriores e posteriores, ou seja, é necessária uma incorporação temporal.

É por meio da interação com os outros que adquirimos habilidades narrativas e essas narrativas, são recursos conversacionais, dispositivos lingüísticos que podem ser usados para indicar ação (GERGEN, 1997).

Para ser eficaz uma narrativa precisa atender a formas convencionais, do contrário não pode ser entendida. São os seguintes critérios de inteligibilidade de uma narrativa: estabelecer um ponto aonde se quer chegar, explicar um acontecimento, evitar ou atingir uma meta; selecionar eventos, os mais acessíveis, mais pertinentes, mais vívidos; ordenar os eventos numa cronologia culturalmente aceitável; apresentar uma identidade estável exceto quando a própria mudança é o ponto chave da narrativa; apresentar ligações causais entre os eventos e, finalmente, ter sinais de demarcação de início e finalização (GERGEN, 1997)

Variadas perspectivas vêm se consolidando no terreno de pesquisas narrativas desde a publicação do clássico Narrative Psychology, editado por Sarbin (1986), naquele momento utilizando o termo "psicologia narrativa" de 
modo abrangente para designar o recente interesse da Psicologia pela natureza narrativa da ação humana e para reunir teóricos comprometidos em dirigir sua atenção para a produção, narração e compreensão de histórias (GERMANO; CASTRO, 2010).

Desde os anos 80 do século $\mathrm{XX}$, os estudos de narrativas avançaram consideravelmente no campo da psicologia social, da personalidade, do desenvolvimento, da psicologia cognitiva, da psicologia clínica, lado a lado com muitas disciplinas afins (Sociologia, Antropologia, Filosofia, Comunicação, Linguísitca, Literatura, Medicina etc). Desde então vem ocorrendo uma remodelação do próprio conceito de narrativa, levando muitos teóricos a minimizar o foco da narrativa como espelho de uma realidade preexistente fora da prática discursiva, e realçar o aspecto construtivo da narração humana (GERMANO; CASTRO, 2010).

A narrativa se tornou uma metodologia de pesquisa bastante aproveitada em diversas áreas, sendo considerada a principal forma de expressão utilizada pelas pessoas para contarem suas histórias coletivas ou individuais (SILVA; TRENTINI, 2002).

Na Psicologia ela tem sido abordada por Bruner, Sarbin, Gergen, entre outros para quem a produção de histórias sobre si mesmo constituem-se um método de acesso ao outro e de troca com o outro.

Narrativa é uma forma universal encontrada em todas as culturas, e por meio desta as pessoas expressam suas percepções e o modo de interpretar os acontecimentos. Narrar é uma manifestação que acompanha o homem desde a sua origem (SILVA; TRENTINI, 2002). Através da narrativa as pessoas relembram acontecimentos, os colocam em uma sequência e encontram 
possíveis explicações por meio das quais constroem a vida individual e social.

Contar histórias envolve estados intencionais que aliviam, ou ao menos tornam familiares, acontecimentos e sentimentos que confrontam a vida cotidiana normal (JOVCHELOVITCH; BAUER, 2008).

Comunidades, grupos sociais e subculturas contam histórias com palavras e sentidos específicos a sua experiência e ao seu modo de vida, não havendo, portanto, experiência humana que não possa ser expressa na forma de uma narrativa.

A narrativa está presente no mito, lenda, fábula, conto, novela, epopéia, história, tragédia, drama, comédia, mímica, pintura (pensemos no Santa Úrsula de Carpaccio), vitrais de janelas, cinema, histórias em quadrinho, notícias, conversação. Além disso. Sob esta quase infinita diversidade de formas, a narrativa está presente em cada idade, em cada lugar, em cada sociedade; ela começa com a própria história da humanidade e nunca existiu, em nenhum lugar e em tempo nenhum, um povo sem narrativa. Não se importando com boa ou má literatura, a narrativa é internacional, trans-histórica, transcultural: ela está simplesmente ali, como a própria vida (ROLAND BARTHES, 1993 apud JOVCHELOVITCH; BAUER, 2008, p. 91).

Gergen (1997) chama atenção para um aspecto importante considerando que em uma narrativa, muitas vezes ações de outras pessoas estão presentes junto às ações do protagonista, ou seja, de quem conta a sua história, podendo colocar em risco a validade da narrativa, que então dependeria também da concordância e afirmação dos outros. No entanto outros autores como Mishler (1986) e Bruner (1997) argumentam que há que se considerar a versão de quem conta a história, pois esta é a sua verdade. É essa versão que oferece elementos para que se possa compreender o indivíduo e suas razões para assim se apresentar ao outro. 
Não temos aqui a pretensão de contestar a veracidade dos fatos incluídos na história, mas sim compreender qual a relação dos mesmos com a identidade da pessoa que vivenciou o adoecimento (câncer de mama). A validação da narrativa é feita, neste caso, por meio da submissão (apresentação) da história contada à apreciação de quem a contou.

\subsection{Narrativa no contexto da saúde/doença}

A importância e o amplo uso das narrativas, como um recurso coerente e adequado para se obter informação acerca das práticas e saberes em saúde de um grupo, pode ser confirmado em alguns estudos, uma vez que as narrativas permitem que seja mantido o elo fundamental entre saber e contexto (RABELO, 1994).

As narrativas criam um campo de ação coletiva e permitem aos profissionais de saúde a construção de conhecimento alicerçado na experiência das pessoas. Por meio das narrativas, podemos ter acesso à experiência do outro de modo indireto, pois a pessoa traz sua experiência a nós da maneira como ela a interpretou. Muitas vezes, ao analisarmos a condição de saúde das pessoas, limitamo-nos a interpretar sinais e sintomas e avaliar tratamentos, desconsiderando, na maioria das vezes, a experiência da doença como um todo. Isto se torna ainda mais relevante ao estudarmos pessoas em condições crônicas, em que a doença não é algo passageiro, mas está presente na vivência do dia a dia (SILVA; TRENTINI, 2002; GARRO, 1994). 
Estudos revelam que as informações obtidas, sejam para fins de pesquisa ou para a prática assistencial de cuidado, precisam ser analisadas tendo como referência o contexto das pessoas informantes. Para isso, é necessária uma ampliação na maneira de se obter informações em relação à visão de mundo do informante (SILVA; TRENTINI, 2002; GARRO, 1994).

A pessoa fala de suas experiências, se refere a eventos passados de uma maneira congruente com sua compreensão atual, reconta o acontecimento a partir de novas reflexões sobre a experiência passada; o presente é explicado tendo como referência padrões de comportamentos socialmente estabelecidos (GARRO, 1994; RABELO, 1994). Essa compreensão da narrativa permite perceber a realidade como um processo dinâmico, criativo, em que tanto o narrador quanto a realidade renascem, tornando única cada narrativa (FRID; ÖHLÉN; BERGBOM, 2000).

As histórias que as pessoas contam sobre suas vidas e sobre como é viver com uma doença, representam a expressão de uma experiência que foi sendo construída nas interações sociais, nas análises compartilhadas sobre os acontecimentos vividos e nas versões reelaboradas desses acontecimentos (GOOD, 1995).

Com a vivência do adoecimento, as pessoas passam a ter outra história para contar. Essas histórias não são histórias separadas do processo de viver, mas são convergentes à maneira de ver o mundo e de viver nele, passando a integrar-se a esse mundo. Ao compreenderem o sentido de uma história, as pessoas captam a experiência ali contida, porém a experiência de uma pessoa não pode se tornar diretamente a experiência de outra, o que é possível transferir é a significação dessa experiência. Desse modo, as pessoas, ao 
narrarem sua experiência, abrem seu discurso de modo a permitir a apreensão de sua significação por outras pessoas (STEVENS; HALL; MELEIS, 1992).

Ao narrarem, as pessoas estão buscando dar um significado para o que Ihes aconteceu, estão procurando construir sua identidade. Suas falas nem sempre são colocadas de modo claro e seus princípios podem estar ou não sistematizados (SILVA; TRENTINI, 2002).

O processo de interpretação de uma narrativa exige grande concentração e um mergulho profundo naquilo que está sendo dito. Para isso, é necessário captar não só o que é dito, mas também a referência que a pessoa utiliza. Essa referência é a apreensão da visão de mundo, ou seja, dos pressupostos que ela utiliza para definir e delimitar sua experiência. Pressupostos são premissas, que, na maioria das vezes, não são ditas, mas que são vivenciadas e que se mostram nas ações, orientando, também, as análises que a pessoa faz de suas experiências. Desse modo, os pressupostos também se evidenciam naquilo que é selecionado para ser contado e naquilo que é valorizado nesse contar (SILVA; TRENTINI, 2002).

Outro aspecto que também está envolvido em uma narrativa é o ouvinte. A pessoa organiza sua narrativa também considerando quem a está ouvindo e, tenta guiar a impressão que o outro terá a seu respeito, geralmente projetando uma imagem favorável de si (RIESSMAN, 1990).

Ao contarem suas histórias sobre a vivência com o adoecimento, as pessoas estão empenhadas em que esse adoecimento faça sentido para elas, e tentam, de alguma maneira, influenciar o futuro (SILVA; TRENTINI, 2002). Contar histórias sobre o adoecimento, portanto, é uma forma de tornar a experiência passada disponível para outros, que as recontarão, criando, então, 
uma rede de informações que permitirão sempre um novo contar sobre sua própria experiência a partir de outras experiências (GOOD, 1995).

A contribuição das narrativas pode ser vista especialmente na realização de pesquisas envolvendo pessoas em condição crônica de saúde, pois ela permite ir além de apenas historiar o adoecimento, captando o seu significado na vida dessas pessoas (SILVA; TRENTINI, 2002).

O estudo das experiências traumatizantes como viver com uma doença crônica e seu tratamento, põe em relevo nossa rotina destacando a maneira pela qual um sentido vivido de coerência, unidade e significado, normalmente prevalecem. Quando tal sentido é interrompido por um trauma, a importância das narrativas mais uma vez entra em rigor, auxiliando o indivíduo na recuperação de um sentido de ordem, de significado, de identidade coerente. Estabelecer um foco na experiência, combinada com a análise de como as pessoas tentam recuperar a ordem face à incoerência traumática, é vista como uma tarefa importante. Para tal, é necessário partirmos de uma perspectiva psicossocial, e considerar o que Murray (2000) chama de nível pessoal de análise das narrativas (CROSSLEY, 2000).

Muitos estudos mostram que durante e depois de enfermidades, não só o corpo, mas também a identidade pessoal está ameaçada, de modo que os indivíduos recorrem às narrativas para reconstruir um sentido coeso de seu corpo e de sua pessoa (CROSSLEY, 2000).

Ao considerarmos o "self" ou identidade, muitas vezes ameaçado pela experiência de um adoecimento grave, é necessário lembrar que este é intrinsecamente dependente da linguagem e das práticas lingüísticas que usamos em nossa vida para fazer sentido, para termos percepção de nós 
mesmos e dos outros. Fazendo uso de tal linguagem estamos constantemente interpretando e mudando o significado de nossas ações e dos outros de acordo com nossas questões práticas e morais (CROSSLEY, 2000).

O enquadre narrativo se refere a que toda experiência humana é feita de significado, compreensão e interpretação e está relacionada a fatores de tempo e sequência. Então, para definir e interpretar o que exatamente aconteceu em certa ocasião, a sequência de eventos é extremamente importante. Uma descrição válida da experiência individual exige uma compreensão da conexão indissociável entre temporalidade e identidade (CROSSLEY, 2000).

Outra característica importante da ordem do sentido relacionada à consciência humana é a de relações e conexões e, nestes termos de relações e conexões, interpretamos os acontecimentos ao nosso redor. Quando nos questionamos sobre o significado de algo, estamos nos perguntando como algo está relacionado ou ligado a algo ou alguém, portanto, são as conexões e relações entre os eventos que constituem o seu significado.

Muitos autores concordam com estes princípios de temporalidade e conexão como Carr (1986), Maclntyre (1981) e Sarbin (1986) ao apresentarem a idéia de que a mente humana tem uma estrutura narrativa essencial. Sarbin (1986) denomina de princípio narrativo, a idéia de que todo ser humano pensa, percebe, imagina, interage e faz escolhas morais de acordo com estruturas narrativas, sendo, portanto, a narrativa, um princípio organizador da ação humana. Tal princípio da narrativa invoca uma imagem humanística do self como contador de histórias, de heróis e vilões, cenas e imagens de atores que dialogam com outros atores. 
Crossley (2000) propõe que o enquadre narrativo compreende uma ferramenta útil que nos torna capazes de recapturar o modo em que selfs e identidades são fundamentados em formas culturais de linguagem e fazem sentido, enquanto ainda mantém um sentido interno, coerente e de natureza pessoal da própria experiência.

Considerando a concepção de estrutura narrativa da experiência humana, Carr (1986) argumenta que a narração está entrelaçada à ação, dando sentido no curso da própria vida. Quando se refere à narração, não se está apenas referindo ao fato de que grande parte de nossas conversas cotidianas são direcionadas a contar histórias. Seu ponto sobre narrativa tem mais a ver com seu papel de constituir o sentido de ações nas quais nos envolvemos e eventos que vivemos, seu papel de organizar temporalmente e dar forma e coerência à sequência de experiências e, sobretudo a mostrar ao outro quem somos nós.

Muitos estudos sobre doenças crônicas têm retratado o impacto que elas podem ter na vida da pessoa. A experiência de uma doença crônica ou grave pode ser vista como uma experiência traumática, um "assalto ontológico" em que algumas das mais básicas suposições existenciais que a pessoa tem sobre ela mesma e o mundo encontram-se em desordem (JANOFF-BULMAN, 1992; KLEINMANN, 1988; TAYLOR, 1989). Outras abordagens falam sobre "rompimento biográfico" para caracterizar o impacto que doenças físicas podem ter no indivíduo (BRODY, 1987; BURY, 1982; YARDLEY, 1997). Todos esses estudos compartilham o pressuposto de que a vinda da doença física traz um conjunto de desafios relacionados a concepções interligadas ao indivíduo de corpo, self e mundo. 
A experiência de uma doença crônica constitui um rompimento na vida e na identidade da pessoa que recebe um diagnóstico de doença grave. Com o adoecimento, a pessoa é colocada fora da complacência da futuridade assumida de sua existência e de sua concepção de si mesma, sua vida e seu mundo provavelmente sofram mudanças radicais (CROSSLEY, 2000).

Essa interrupção da experiência do tempo vivido é relatada como uma desestruturação do mundo à medida que pessoas têm um sentido de identidade. Quando as pessoas falam ou escrevem sobre suas experiências com doenças crônicas ou graves, também falam das mudanças que sofreram e do surgimento de novas identidades. Essa noção refere-se ao modo como a doença grave é percebida mudando totalmente a vida da pessoa. Este tema é recorrente na literatura autobiográfica relacionada a todos tipos de doença crônica (CROSSLEY, 2000).

Estudos que abordam experiências com doenças crônicas e graves constituem exemplos do modo como nossa rotina "vivida" no sentido de tempo e identidade tem uma ligação implícita e coerente. Esse sentido é interrompido pelo trauma, que carrega uma capacidade devastadora de desestruturar o mundo. É em face de tal incoerência que narrativas e histórias se tornam importantes. Não vivemos apenas rotineiramente e projetamos em acordo com um implícito, fenomenológico, sentido de ligação e ordem, mas também quando tais ligações são quebradas tentamos reconstruí-las através da utilização de histórias e narrativas (CROSSLEY, 2000). Como Brody (1987) argumenta, o sofrimento é produzido e aliviado principalmente pelo significado que as pessoas atribuem a suas experiências. Um dos principais mecanismos para atribuição de significado às experiências é o contar histórias, tais 
atividades assumem um papel central no estudo de experiências de doenças e traumas. Broyard (1992, p.27) escreve:

\begin{abstract}
Sempre em emergências inventamos narrativas. Nós descrevemos o que está acontecendo como se para limitar a catástrofe. Quando pessoas ouvem que eu estava doente, eles me inundam com histórias de suas próprias doenças, bem como casos de amigos. Contar histórias parece ser uma reação natural à doença. Pessoas sangram histórias e eu me tornei um banco de sangue delas.
\end{abstract}

A importância de histórias e narrativas está sendo cada vez mais considerada na pesquisa atual sobre o modo como as pessoas vivem com doença grave. Nos últimos anos, numerosos estudos têm olhado para como pessoas lidam com os efeitos perturbadores da dor, doença e eventos traumáticos através da história contada e do processo de reconfiguração narrativa (CROSSLEY, 2000). Tal configuração narrativa consiste de um processo através e pelo qual o indivíduo tenta restabelecer um nível de segurança ontológica e um renovado sentido de significado, ordem e ligação com sua vida (DAVIES, 1997). Como Mathieson e Stam (1995) argumentam, o contar tais histórias é o veículo para fazer sentido não apenas de uma doença, mas da própria vida. A mais catastrófica doença é a mina de significado e de mudança de vida potencial.

A experiência de eventos traumáticos como uma doença grave é fundamental para facilitar uma apreciação do modo pelo qual a vida humana está narrativamente configurada. A experiência de eventos traumáticos, muitas vezes, serve para perturbar a rotina e sentido de ordem da existência, colocando em dúvida nossas tomadas de decisão sobre tempo, identidade, significado e vida própria. Quando isso acontece é possível examinar o modo 
com as narrativas tornam-se importantes em outro sentido. Isso é em termos do modo em que são utilizadas para restaurar um sentido de ordem e ligação e então restabelecer um aparente significado na vida do indivíduo e o sentido de si mesmo. Portanto, narrativas de doenças são utilizadas, pois ajudam a revelar estruturas ou significados que tipicamente permanecem implícitos ou desconhecidos, potencializando assim uma transformação de vida e elevação a outro nível (CROSSLEY, 2000).

Em trabalho que relaciona identidade pessoal e sobrevivência, Little et al. (2002) trazem o conceito de identidade pessoal como definida por personificação, continuidade e memória. Memória, nesse contexto, engloba o que chamam de memória futura. Considerando que cognitivamente atribuímos significado a eventos de nossas vidas nos contextos passado, presente e futuro; podemos interpretar os eventos da memória do passado de modo narrativo, pois estes já ocorreram, assim como podemos interpretar os eventos do presente, porque a continuidade da memória contribui para o que nós consideramos aqui e agora. Mas essa continuidade estende-se ao futuro, não sendo o mesmo que planos e expectativas, e sim um ato de imaginação que tecemos olhando para eventos que devem ocorrer. Isso é o significado biográfico que atribuímos a planos e expectativas e forma a base para a continuidade de nossas vidas no futuro. Nossos planos e expectativas podem mudar sem ameaçar a nossa identidade, mas interrupções da memória futura têm conseqüências profundas.

Identidade então, para nossos propósitos, é o sentido de personalidade que coloca cada um unicamente em contexto social. O sentido de identidade é, assim, o sentido de organismo, o sentido de que isso é sua vontade, 
escolhendo e agindo, tanto agora e no futuro. Identidade é o sentido de ser essa pessoa com atributos (como sexo, físico, inteligência, resistência, saúde) aquisições (tais como rico, pobre, classificação, educação, formação, realizações) e capacidades (incluindo trabalho, poder, vulnerabilidade, reputação, estado, aprovação) que interagem entre pessoa e sistema social em que ele ou ela vivem. Isso é construído e experienciado pela pessoa, mas essa experiência é construída e modificada por eventos e associações dentro das quais a pessoa se desloca. Ao mesmo tempo, diferentes percepções de identidade pessoal são atribuídas à pessoa por outros, e o sentido subjetivo de identidade e percepções externas de identidade envolvem reflexivamente um ao outro. Em narrativa, esse engajamento reflexivo é expresso no discurso da identidade pessoal (LITTLE et al., 2002).

Experiências extremas, incluindo a doença câncer, causam descontinuidade no sentido de identidade. O sentido de descontinuidade emergiu nas histórias contadas por pacientes cujas identidades foram seriamente desafiadas por experiências de adoecimento. Por meio das narrativas dos participantes do estudo, os autores apontam formas que podem ser utilizadas para lidar com esta descontinuidade da identidade:

1. Anchor Points - ou seja, pontos de apoio, que são valores, crenças ou recursos que as pessoas se utilizam para permanecerem firmes contra a turbulência da experiência extrema, no caso, o adoecimento por câncer.

2. Retomada - algumas pessoas que sobreviveram a experiências extremas parecem reconstruir sua identidade acomodando a experiência e suas seqüelas - ou seja, eles retomam uma versão de suas vidas anteriores dentro do contexto de suas personificações mudadas e novos pensamentos. Apesar 
da experiência e suas seqüelas, no mínimo alguns importantes aspectos da identidade pré existente permanecem intactos.

3. Incorporação - a pessoa reconstrói sua identidade, contudo, incorpora a experiência a que foi submetida voltando-se ao benefício do outro. Incorporação difere de reconstrução. Enquanto reconstrução enfatiza o que está inalterado pela experiência, incorporação reconhece a oportunidade oferecida pela experiência para desenvolver e expandir uma faceta pré existente da identidade. Pessoas podem tanto reconstruir versões de suas vidas anteriores como ampliar aspectos da nova vida pelo ato de incorporação. Reconstrução pode ser vista como um meio de preservar uma continuidade linear; incorporação como um meio de aprimorar a identidade.

4. Atribuindo significado à experiência extrema - para alguns, a busca de significado em sua experiência permite a aceitação da experiência como um evento formativo. Se virmos reconstrução como preservação de uma continuidade linear e incorporação como aprimoramento da identidade, atribuir significado pode ser visto como um modo de ampliação da identidade, um acréscimo de novos componentes à identidade que tornam-se disponíveis devido à experiência extrema.

5. A importância da memória futura - para alguns, memória futura retém um importante lugar na construção da identidade.

6. Alienação - algumas pessoas parecem perder seu sentido de continuidade pessoal após um evento extremo.

Uma vez que a fase aguda do tratamento da doença está concluída, e especialmente quando a cura parece provável, o status de sobrevivente é 
notavelmente incerto. A narrativa da doença tem contribuído muito para legitimar a experiência da doença (FRANK, 1993; 1995; KLEINMAN, 1988), mas sobrevivência é ainda objeto pouco abordado. O trabalho científico de Frank (1993; 1995) é notável pela atenção à experiência da sobrevivência.

O papel do sobrevivente está mal mapeado e frequentemente está relacionado apenas em termos de busca heróica ou restituição (Frank, 2012). Qualidades como normalidade, heroísmo, fortuna, sorte, sucesso, covardia, falha, entrega, tornam-se padrões de definição para comportamentos de sobreviventes. O espectro para respostas socialmente legítimas para estados existenciais de sobreviventes, é, portanto, estreitamente definido (LITTLE et al., 2002).

Ainda mais, sobrevivência funde-se com "cura" e "normalidade" na avaliação comum. Sobrevivência é pensada como não tendo valor tão grande. O que parece ser esperado para o sobrevivente, é, portanto, gratidão eterna dentro do contexto de normalidade de mais experiência de vida. A identidade do sobrevivente, se concebida ao todo, é moldada como de alguém normal, tendo relações normais com eventos e com os outros. As tensões existências contínuas do sobrevivente ainda recebem pouco reconhecimento ou simpatia.

Em seus estudos sobre narrativas de adoecimento e auto-mudança, Frank (1993) descreve sobre como certos eventos e experiências são compreendidos como ocasiões para mudanças do self, principalmente 0 adoecimento. Ele percebeu que na maioria das narrativas de adoecimento há referência à nova pessoa que o adoecimento produziu a partir do antigo self, afirmando ainda ser a narrativa uma oportunidade de a pessoa recuperar 0 autoconhecimento perdido com a experiência do adoecimento. 
Frank (2012) relaciona a doença a uma epifania, considerando como epifania um momento privilegiado em sua possibilidade para mudar a vida. Com o adoecimento, a pessoa doente passa a explorar um novo potencial e padrões adequados que a ajudam a definir uma nova existência.

A narrativa do adoecimento traz uma apresentação pública de quem a pessoa se tornou. Frank (1993; 1995), em suas contribuições, trabalhou com narrativas de adoecimento publicadas em livros e histórias construídas no contexto de entrevista. Neste estudo em particular, utilizaremos narrativas obtidas a partir de entrevistas que não foram publicadas.

Frank (2012) identificou três principais tipos específicos de narrativas que utilizaremos na análise das narrativas obtidas nas entrevistas do presente estudo. Segundo ele, os três tipos de narrativas são: as narrativas de restituição - são aquelas em que a alguém fica doente, é tratado, o tratamento é eventualmente um sucesso, e a pessoa se restabelece a, pelo menos, uma razoável aproximação da vida que tinha antes da doença; as narrativas de caos - caracterizadas por um protagonista que tem múltiplos problemas, cristalizados por uma doença (ou doenças), mas geralmente não limitados a essa doença. Uma coisa ruim leva a outra e a vida vai desmoronando ao redor dessa pessoa, sem que ela consiga restabelecer-se; e as narrativas de busca baseadas em uma explícita ou implícita metáfora de viagem (percurso, caminho). Em termos de gênero elas são romances (novelas), em que um personagem encontra uma sequência de obstáculos e ganha sabedoria e estatura por meio do processo de superação destes.

Neste estudo, tendemos a analisar as narrativas na perspectiva do impacto da doença, o câncer de mama, sobre a vida pessoal do doente, sobre 
a perda e a reconstituição do sentido de si mesmo e o papel organizador das narrativas. Aqui se concebe a doença como um evento que desestabiliza a vida e o sentido de identidade do doente e as narrativas como recursos que não somente dão voz a este "self" transformado, como também permitem a reconstituição de si e o enfrentamento da nova condição de sobrevivente.

Frente às colocações acima, considerei a análise de narrativas formuladas por pessoas, neste caso mulheres, que passaram pelo câncer de mama e sobreviveram a ele como o recurso que possibilitaria alcançar os objetivos deste estudo. 


\section{Percurso metodológico}

\subsection{Caracterização do estudo}

Uma vez que o presente estudo tem por objetivo compreender a experiência de sobreviver ao câncer de mama, por meio da análise das narrativas, entendo que a opção metodológica adequada é abordagem metodológica qualitativa. Minayo (2007) afirma que a metodologia qualitativa preocupa-se com os significados, motivos, aspirações, crenças, valores e atitudes decorrentes de ação humana objetiva, apreendidos no cotidiano, da experiência e da descrição das pessoas que vivenciam determinado fenômeno.

Para Polit e Hungler (1995), a pesquisa qualitativa baseia-se na premissa de que os conhecimentos sobre as pessoas só são possíveis com a descrição da experiência humana, tal como é vivida e definida por seus atores. A abordagem qualitativa revela ainda o interesse no microssocial, com base nas palavras, histórias e narrativas, cujo objetivo é a dimensão subjetiva, ou seja, as experiências e os processos de significação nos quais o olhar central está no reconhecimento do ponto de vista do outro e nas ações observáveis (TURATO, 2005).

No contexto da metodologia qualitativa aplicada à saúde, não se busca estudar o fenômeno em si, mas entender seu significado individual ou coletivo para a vida das pessoas. Assim, saber o que os fenômenos do adoecimento e da vida em geral representam para elas, torna-se imprescindível.

O ambiente natural do sujeito é inequivocamente o campo onde ocorrerá a observação, sem controle de variáveis. No estudo qualitativo em saúde o 
pesquisador é o próprio instrumento de pesquisa, usando diretamente seus órgãos do sentido para apreender os objetos em estudo, espelhando-os então em sua consciência onde se tornam fenomenologicamente representados para serem interpretados. O pesquisador também pode recorrer aos conhecimentos e experiências pessoais como auxiliares nos processos de compreensão e interpretação do fenômeno estudado (TURATO, 2005).

Com relação à validade dos dados coletados, a pesquisa qualitativa proporciona alta qualidade, já que a observação dos sujeitos, bastante acurada, e sua escuta, em profundidade, tendem a levar o pesquisador bem próximo da essência da questão em estudo. É importante manter uma atitude flexível e aberta, admitindo que outras interpretações podem ser sugeridas, discutidas e igualmente aceitas. A validade dos dados da pesquisa qualitativa acontece à medida que o estudo revela uma descrição acertada das experiências dos indivíduos e que as pessoas ao terem esta experiência reconheceriam imediatamente aquelas descrições ou interpretações como sendo delas próprias (TURATO, 2005).

Acreditamos que ao compreendermos o significado da experiência de sobreviver ao câncer de mama, estaremos contribuindo com as reflexões sobre atuação e planejamentos de ações dos cuidados em saúde para essa clientela. Com essa finalidade, a abordagem de pesquisa qualitativa seria a mais adequada para atender aos objetivos do estudo, uma vez que o mesmo utilizará de descrição e interpretação de fenômenos relacionados ao adoecimento e à sobrevivência ao câncer de mama. 


\subsection{Procedimentos}

O primeiro passo rumo à efetivação deste estudo aconteceu por meio de um encontro entre a pesquisadora e uma oncologista de um serviço do Sistema Único de Saúde (SUS) que atende diariamente pacientes oncológicos de diferentes diagnósticos, em que a pesquisadora expôs os objetivos de sua pesquisa e questionou sobre a possibilidade de convidar os pacientes atendidos no serviço a participarem. A pesquisadora foi apresentada à psicooncologista do serviço e conversaram juntamente ao diretor sobre a viabilização da pesquisa. Ambos os profissionais permitiram que a pesquisadora realizasse a pesquisa no local e tivesse acesso aos prontuários dos pacientes para selecionar aqueles que seriam convidados à participação, mediante autorização do diretor geral do hospital, onde se localiza o serviço, e aprovação do projeto pelo Comitê de Ética em Pesquisa.

Após a autorização do diretor geral para a realização da pesquisa, o projeto foi submetido ao Comitê de Ética e Pesquisa em Seres Humanos da Escola de Enfermagem de Ribeirão Preto, tendo sido aprovado sob protocolo n. 1285/2011 em 07 de abril de 2011 (Anexo A).

Como parte da documentação prevista na legislação, elaboramos o "Termo de Consentimento Livre e Esclarecido" (Apêndice A), pelo qual, em linguagem clara e objetiva, os participantes foram informados sobre o objetivo da pesquisa; os procedimentos de risco, desconfortos e benefícios; garantia de anonimato e respeito ao desejo de participar ou não do estudo.

A inserção no campo empírico aconteceu em abril de 2011 onde a pesquisadora teve contato com os profissionais do serviço a fim de 
obter informações sobre o funcionamento do mesmo e da demanda dos pacientes ali atendidos. Tais profissionais nos ajudaram a entrar em contato com os potenciais participantes do estudo.

Nossa intenção inicial era abordarmos pessoas sobreviventes de diferentes diagnósticos de câncer, homens e mulheres. No entanto, a partir de informações obtidas no serviço, havia ali o predomínio de pacientes mulheres sobreviventes de câncer de mama. Assim, optou-se por delimitar os participantes desse estudo com essas características.

A pesquisadora teve acesso aos prontuários dos pacientes com a finalidade de identificar os potenciais participantes do estudo, obtendo os dados daquelas que seriam convidadas à participação.

Participaram da pesquisa 15 mulheres com idades entre 48 e 81 anos que receberam o diagnóstico de câncer de mama, independente da histologia, e que haviam concluído o tratamento há, no mínimo, cinco anos, encontrandose sem sintomas doença. Por tratamento aqui consideramos os procedimentos de cirurgia, quimioterapia e/ou radioterapia. Este critério foi definido com base na literatura da área, que apresenta como uma das definições para "sobrevivente", a pessoa que está livre dos sintomas da doença no período mínimo de cinco anos. Para confirmação de que a paciente estivesse sem sintomas da doença, foram observados em seus prontuários dados relativos à data do diagnóstico, data da cirurgia, início e fase em que estava da terapia hormonal (duração mínima de 60 meses).

Todas as entrevistadas foram submetidas à cirurgia (mastectomia total ou parcial ou quadrantectomia) seguida de radioterapia e/ou quimioterapia e estavam finalizando a terapia hormonal no momento do convite à participação. 
Destas 15 mulheres, uma foi submetida apenas à cirurgia, uma recebeu apenas a quimioterapia, duas apenas a radioterapia e 11 receberam quimioterapia e radioterapia associadas. No momento da entrevista 10 participantes estavam casadas, duas divorciadas, uma solteira e duas viúvas, sendo que 12 tinham filhos. O tempo transcorrido do diagnóstico à época da entrevista compreendeu entre cinco anos e sete anos aproximadamente. Com relação à escolaridade, cinco participantes concluíram o nível superior, seis possuíam o ensino médio e quatro não completaram o ensino fundamental. É importante ressaltar que foram utilizados nomes fictícios para resguardar as verdadeiras identidades das participantes.

Das 15 entrevistas realizadas, três não puderam ser utilizadas para a análise. Tal fato ocorreu devido às seguintes situações: a primeira delas referese ao estudo piloto, a partir do qual reformulamos a questão inicial da entrevista e também adequamos melhor a técnica; a outra situação se refere a uma participante já idosa que demonstrou, na ocasião da entrevista, não ter conhecimento de seu diagnóstico, inviabilizando que a pesquisadora abordasse o assunto da sobrevivência ao câncer de mama; a terceira e última situação ocorreu pelo fato de outra participante, no momento da entrevista, embora tivesse aceitado ser entrevistada pela pesquisadora mostrou-se, na ocasião, reticente quanto a levar adiante a entrevista.

O número de participantes foi estipulado de antemão em 15, considerando os seguintes fatores:

1. Apontamentos na literatura sobre o número de participantes de estudos que envolvem entrevistas e sua análise serem em torno de 20 (DUARTE, 2002). 
2. Este número poderia ser mantido ou modificado conforme a necessidade do pesquisador em identificar nas entrevistas elementos que pudessem dialogar com o suporte teórico metodológico adotado.

3. A análise das entrevistas requer exaustivos mergulhos no material coletado, tornando inviável o trabalho com um número grande de entrevistas.

4. Obediência ao cronograma de coleta de dados que se iniciou com os primeiros contatos com o serviço a partir do qual as participantes seriam identificadas e convidadas a participar.

5. O planejamento de pesquisa previu dois momentos de abordagem às participantes, o que demandaria maior tempo de coleta de dados.

Uma vez identificadas as potenciais participantes, mediado por profissionais do serviço de oncologia onde eram atendidas, o convite à participação sucedeu-se por telefone ou pessoalmente, enquanto aguardavam o atendimento médico.

O convite aconteceu da seguinte maneira: "Olá, sou psicóloga e estou realizando uma pesquisa com os pacientes do serviço de oncologia que passaram pelo tratamento do câncer. Gostaria de convidá-la a participar e caso aceite, agendaremos uma conversa, no dia e local que forem mais adequados à senhora". Após a concordância na participação, agendou-se um encontro para a realização da entrevista, sendo respeitados os procedimentos éticos para pesquisas com seres humanos.

Foi realizado estudo piloto a fim de verificar a adequação da técnica aos objetivos propostos e quais as facilidades e dificuldades em sua aplicação. Após a verificação da mesma, foram realizadas as entrevistas. 
As entrevistas foram realizadas nos seguintes locais: sala previamente reservada no serviço de saúde onde a entrevistada realizava tratamento, local de trabalho ou residência da participante.

No momento da entrevista, a pesquisadora apresentou os objetivos da pesquisa, confirmou alguns dados das participantes obtidos nos prontuários (nome, endereço, data do diagnóstico, tratamentos recebidos) e apresentou o Termo de Consentimento Livre e Esclarecido, lido juntamente à participante. Após a apresentação do referido termo e confirmação daquelas que aceitaram participar, enfatizando-se que a participação era voluntária, e que uma eventual recusa não acarretaria prejuízos à continuidade dos atendimentos, foi solicitada a assinatura no termo, ficando uma cópia com a pesquisadora e outra com a participante.

Com o Termo de Consentimento lido e assinado, deu-se início à entrevista propriamente dita (vista de maneira mais detalhada no próximo item).

Para o registro dos relatos e posterior análise, as entrevistas foram gravadas em áudio após o consentimento verbal e por escrito das entrevistadas. Também foram realizados registros durante as entrevistas, para auxílio da pesquisadora, acrescentando detalhes à descrição do momento da entrevista.

As entrevistas tiveram duração média de 48 minutos.

Houve um segundo encontro previamente acordado com todas as participantes, com o objetivo de esclarecer dúvidas, questionar ou acrescentar fatos que julgaram necessários. Neste segundo encontro a síntese da história contada pela participante foi apresentada pela pesquisadora em forma escrita e ambas leram juntas para certificarem-se do conteúdo. 
As entrevistas aconteceram no período de abril a julho de 2011.

3.3 Coleta de dados e análise

\subsubsection{A entrevista narrativa}

Para a obtenção dos dados foi utilizada a entrevista narrativa que tem em vista uma situação que encoraje e estimule o entrevistado a contar a história sobre algum acontecimento importante de sua vida e do contexto social. Neste caso em específico, a participante é estimulada a contar a sua história enquanto uma pessoa que passou pelo câncer e pode ser considerada uma sobrevivente.

A técnica da entrevista narrativa recebe seu nome da palavra latina narrare, relatar, contar uma história (JOVCHELOVITCH; BAUER, 2008). O contar histórias parece seguir regras universais que guiam o processo de produção da história. Schutze (1977; apud JOVCHELOVITCH; BAUER, 2008. p.94) descreve como "exigências inerentes da narração" o que outros chamam de "esquema da história" (JOHNSON; MANDLER, 1980; LABOV, 1972 apud JOVCHELOVITCH; BAUER, 2008). Um esquema estrutura um processo semiautônomo, ativado por uma situação pré-determinada. A narrativa é então eliciada na base de provocações específicas e, uma vez que o informante tenha começado, o contar história irá sustentar o fluxo da narração, fundamentando-se em regras tácitas subjacentes (JOVCHELOVITCH; BAUER, 2008). 
O contar histórias segue um esquema autogerador com três principais características: textura detalhada - refere à necessidade de dar informação detalhada para a compreensão da transição entre um acontecimento e outro. Cabe ao narrador fornecer tantos detalhes quanto forem necessários; fixação da relevância - o contador de história narra àqueles aspectos do acontecimento que são relevantes, de acordo com sua perspectiva de mundo; e fechamento da Gestalt - um acontecimento central mencionado na narrativa tem de ser contado em sua totalidade, com um começo, meio e fim (JOVCHELOVITCH; BAUER, 2008).

A entrevista narrativa é classificada como uma ferramenta utilizada em pesquisa qualitativa. Quanto à sua forma, é considerada uma entrevista não estruturada, de profundidade, com características específicas. O esquema de narração substitui o esquema pergunta-resposta que define a maioria das situações de entrevista e emprega um tipo específico de comunicação cotidiana, o contar e escutar história (JOVCHELOVITCH; BAUER, 2008).

Para conseguir uma entrevista mais apropriada da perspectiva do informante, a influência do entrevistador deve ser mínina e um ambiente deve estar preparado para se conseguir esta minimização da influência do entrevistador. O entrevistador deve estar atento para evitar impor qualquer forma de linguagem não empregada pelo informante durante a entrevista (JOVCHELOVITCH; BAUER, 2008).

A narrativa se processa por meio de quatro fases: começa com a iniciação, move-se por meio da narração e da fase de questionamento e termina com a fase da fala conclusiva. Em cada uma dessas fases é apresentado um conjunto de regras que servem para orientação do 
entrevistador, a fim de fazer com que haja uma narração mais rica sobre um tópico de interesse, evitando o esquema pergunta-resposta (JOVCHELOVITCH; BAUER, 2008).

A preparação da entrevista exige uma compreensão preliminar do acontecimento principal. O pesquisador monta uma lista de questões que refletem seus interesses, suas formulações e linguagem. Deve-se ter em mente que o tópico inicial da entrevista narrativa representa os interesses do entrevistador. Fase 1) iniciação: o contexto da investigação é explicado em termos amplos ao informante. Deve-se pedir a ele permissão para gravar a entrevista, o que possibilita uma análise adequada posteriormente. 0 procedimento da entrevista narrativa é então brevemente explicado ao informante: a narração sem interrupções, a fase de questionamento e assim por diante. A introdução do tópico inicial deve deslanchar o processo de narração. A fim de eliciar uma história que possa ir adiante, algumas regras podem ser empregadas como orientações para formular o tópico inicial: o tópico inicial necessita fazer parte da experiência do informante, o que garantirá seu interesse e uma narração rica em detalhes; deve ser de significância pessoal e social, ou comunitária; o tópico deve ser amplo permitindo ao informante desenvolver uma história longa que, a partir de situações iniciais, passando por acontecimentos passados, leve à situação atual; evitar formulações que referem datas, nomes ou lugares. Fase 2) narração central: quando a narração começa, não deve ser interrompida até que haja uma clara indicação de que a história terminou. Durante a narração o entrevistador se abstém de qualquer comentário, restringe-se à escuta ativa e ao apoio não verbal ou paralinguístico. O entrevistador pode tomar notas 
ocasionais para perguntas posteriores. Quando o informante indica o final da história, investiga-se por algo mais: "É tudo o que você gostaria de me contar?" Ou "Haveria ainda alguma coisa que você gostaria de dizer?". Fase 3) fase de questionamento: quando a narração chega a um fim natural, inicia-se a fase de questionamento em que o entrevistador traz questões para completar as lacunas da história. Algumas regras básicas se aplicam: não fazer perguntas do tipo "por quê?", apenas perguntas que se refiram aos acontecimentos, como: "O que aconteceu antes/depois/então?"; fazer perguntas referentes aos acontecimentos mencionados na história e relevantes aos tópicos de pesquisa empregando somente palavras do informante; não apontar contradições na narrativa. A fase de questionamento tem como finalidade eliciar material novo e adicional além do esquema autogerador da história. As fases 1, 2 e 3 são gravadas para transcrição literal, com o consentimento dos informantes. Fase 4) fala conclusiva: no final da entrevista, quando o gravador estiver desligado, muitas vezes acontecem discussões interessantes na forma de comentários informais. Essa informação contextual se mostra, em muitos casos, importante para a interpretação dos dados, e pode ser utilizada na interpretação contextual das narrativas do informante. O registro dessas informações poderá sem feito em um diário de campo, ou em um formulário especial para sintetizar os conteúdos dos comentários informais, imediatamente após a entrevista (JOVCHELOVITCH; BAUER, 2008).

As regras da entrevista narrativa definem um procedimento de tipo ideal, que apenas poucas vezes pode ser seguido. A interação entre a narração e o questionamento pode ocasionalmente diluir as fronteiras entre a entrevista narrativa e a entrevista semiestruturada, surgindo uma nova forma 
de entrevista semiestruturada enriquecida por narrativas. Alguns casos específicos em que a entrevista narrativa é adequada: projetos que investigam acontecimentos específicos, tais como junção de incorporações ou políticas locais; projetos em que variadas "versões" estão em jogo e a diferença nas perspectivas pode estabelecer uma configuração diferente na seleção dos acontecimentos que devem ser incluídos no conjunto da narrativa; e projetos que combinem histórias de vida e contextos sócio-históricos (JOVCHELOVITCH; BAUER, 2008).

A entrevista narrativa foi percebida como uma técnica apropriada para a realização desta pesquisa, visto que no contexto da saúde e em se tratando de sobrevivência ao câncer, permite ao participante contar a sua própria história.

A entrevista iniciava-se com a seguinte questão norteadora: "Eu gostaria que você me contasse a sua história, enquanto uma pessoa que passou pelo tratamento do câncer e hoje pode ser considerada uma sobrevivente”. A partir de então, as participantes passaram à narração de suas experiências, de maneira livre, ancoradas em um ouvir atento e respeitoso, sem pré-concepções.

Outras questões também foram feitas pela pesquisadora durante a entrevista como: "Tem algo que você gostaria de acrescentar na história?" - a fim de melhor compreender o contexto da história da entrevistada.

Para assegurar a credibilidade e validade dos dados, houve um segundo encontro com cada participante, em que a pesquisadora apresentou a síntese da história obtida a partir das narrativas, possibilitando às mesmas que concordassem ou alterassem dados que julgassem necessário. Não houve sugestões quanto a alterações nas sínteses das histórias. 


\subsubsection{Análise dos dados}

A análise dos dados teve início com a ordenação dos dados mediante a transcrição integral das entrevistas gravadas, as quais foram complementadas com as informações obtidas nos prontuários e aquelas registradas no diário de campo. Preservamos as expressões de linguagem usadas pelas participantes, fazendo, no entanto, correções que não alterassem o significado da frase de forma a facilitar a compreensão.

A análise foi guiada pelas proposições de Little et al. (2002) e Frank (2012).

Para garantia do anonimato, respeitando-se as orientações expressas no Termo de Consentimento Livre e Esclarecido, identificamos as participantes atribuindo-Ihes nomes fictícios.

Os trechos que serão apresentados referem-se às falas originais transcritas, identificadas ao final, entre parênteses, pelo nome fictício da participante do estudo.

Durante a análise dos dados, procuramos rever as anotações registradas ao término das entrevistas, e levamos em consideração a concordância das participantes quanto à síntese da história apresentada pela pesquisadora no segundo encontro para validar o conteúdo das historias produzidas. 


\section{Apresentação e discussão dos resultados}

Este capítulo será apresentado em três etapas. A primeira trata da identificação das participantes do estudo. Na segunda etapa será apresentada a análise das narrativas de acordo com as proposições de Little et al. (2002) e na terceira etapa apresentaremos uma análise da tipologia de narrativas proposta por Frank (2012).

\subsection{Identificação das participantes}

Apresentarei a identificação das participantes do estudo com algumas informações como a idade da participante no momento da entrevista, ocupação, estado civil, se tem filhos, com quem reside, a data do diagnóstico, os tratamentos recebidos, o local de realização e a duração da entrevista. Os nomes utilizados são nomes fictícios visando preservar a identidade das participantes.

\section{Anali}

Anali tem 48 anos, trabalha como professora, é casada e tem um filho de 21 anos. Ela mora com o marido e o filho e foi diagnosticada com câncer de mama em 2005, tendo passado por cirurgia, radioterapia, quimioterapia e hormonioterapia. Conforme havíamos combinado, a entrevista aconteceu na residência de Anali, em local reservado, estando presentes apenas a pesquisadora e a entrevistada. A entrevista teve duração de 35 minutos. 


\section{$\underline{\text { Clarita }}$}

Clarita tem 59 anos, trabalha como encarregada de sessão em uma usina de açúcar no interior de MG, é divorciada e tem uma filha de 38 anos. Ela mora sozinha e recebeu o diagnóstico de câncer de mama em 2005, tendo passado por cirurgia, radioterapia e hormonioterapia. Como havíamos combinado, Clarita foi ao serviço de Oncologia para a realização da entrevista, onde estiveram presentes apenas a pesquisadora e a entrevistada. A entrevista teve duração de 38 minutos.

\section{$\underline{\text { Cristine }}$}

Cristine tem 52 anos, é enfermeira, casada e tem dois filhos, um de 25 anos e uma filha de 23 anos. Ela mora com o marido e os filhos. Recebeu 0 primeiro diagnóstico de câncer de mama em 2002 e o segundo em 2006, passando por cirurgia, quimioterapia, radioterapia e hormonioterapia. Como havíamos combinado, a entrevista aconteceu no local de trabalho de Cristine, em espaço reservado, onde estiveram presentes apenas a pesquisadora e a entrevistada. A entrevista teve duração de 43 minutos.

\section{$\underline{\text { Juliana }}$}

Juliana tem 52 anos, é ex-bancária, casada, e tem dois filhos, uma filha de 22 anos e um filho de 20. Ela mora com o marido e o filho e recebeu o diagnóstico de câncer de mama em 2006, tendo passado por cirurgia, quimioterapia, radioterapia e hormonioterapia. A entrevista aconteceu no serviço de Oncologia, em sala reservada, estando presentes apenas a pesquisadora e a entrevistada. A entrevista durou 90 minutos. 


\section{Lorena}

Lorena tem 66 anos, trabalha como contabilista, é solteira e mora com a irmã. Recebeu o diagnóstico de câncer de mama em 2005, tendo passado por cirurgia, quimioterapia, radioterapia e hormonioterapia. A entrevista aconteceu no serviço de Oncologia, em sala reservada, estando presentes apenas a pesquisadora e a entrevistada. A entrevista teve duração de 64 minutos.

Hélia

Hélia tem 58 anos, é funcionária pública municipal, casada e tem um filho de 20 anos. Ela mora com o marido e o filho e recebeu o diagnóstico de câncer de mama em 2005, passando por cirurgia, radioterapia, quimioterapia e hormonioterapia. A entrevista aconteceu no serviço de Oncologia, em sala reservada, estando presentes a pesquisadora, e a entrevistada acompanhada de seu filho. A entrevista teve duração de 39 minutos.

\section{Marina}

Marina tem 54 anos, é secretária, casada, mãe de dois filhos, um de 23 anos e um de 21 anos. Mora com o marido e os filhos. Ela recebeu o diagnóstico de câncer de mama em 2005, tendo passado por cirurgia, quimioterapia, radioterapia e hormonioterapia. A entrevista aconteceu na residência de Marina, em local reservado, estando presentes apenas a pesquisadora e a entrevistada. A entrevista teve duração de 50 minutos. 


\section{Rosangela}

Rosangela tem 55 anos, trabalha como artesã, é casada e mãe de dois filhos, um filho de 24 anos e uma filha de 19 anos. Ela mora com o marido e recebeu o diagnóstico de câncer de mama em 2006, tendo passado por cirurgia, quimioterapia, radioterapia e hormonioterapia. Conforme havíamos combinado, a entrevista aconteceu no serviço de Oncologia, em sala reservada, onde estiveram presentes a pesquisadora, a entrevistada e a filha que acompanhava Rosangela. A entrevista teve duração de 39 minutos.

\section{$\underline{\text { Silene }}$}

Silene tem 71 anos, é aposentada, viúva e mora sozinha. Recebeu o diagnóstico de câncer de mama em 2005, tendo passado por cirurgia, quimioterapia, radioterapia e hormonioterapia. A entrevista aconteceu no serviço de Oncologia, em sala reservada, e estavam presentes apenas a pesquisadora e a entrevistada. A entrevista teve duração de 54 minutos.

\section{Florentina}

Florentina tem 58 anos, é secretária em uma escola, é casada, mãe de dois filhos, um de 27 anos (falecido) e um de 33 anos. Ela mora com o marido e o filho e recebeu o diagnóstico de câncer de mama em 2004, tendo passado por cirurgia e hormonioterapia. A entrevista aconteceu no local de trabalho de Florentina, em espaço reservado, onde estiveram presentes apenas a pesquisadora e a entrevistada. A entrevista teve duração de 50 minutos. 
Velma

Velma tem 51 anos, é casada e não trabalha fora de casa. Ela mora com o marido e recebeu o diagnóstico de câncer de mama em 2006, passando por cirurgia, quimioterapia, radioterapia e hormonioterapia. A entrevista foi realizada no serviço, estando presentes apenas a pesquisadora e Telma. A entrevista teve duração de 41 minutos.

\section{$\underline{\text { Cleusa }}$}

Cleusa tem 65 anos, não trabalha fora de casa, é casada e tem uma filha de 35 anos. Ela recebeu o diagnóstico de câncer na bexiga em 1994, depois de câncer de mama em 2006 e de câncer no intestino em 2011. Para o tratamento do câncer de mama ela foi submetida à cirurgia, radioterapia e hormonioterapia. A entrevista aconteceu no serviço, estando presentes apenas a pesquisadora e Cleusa, e teve duração de 39 minutos.

\subsection{Análise das narrativas}

As narrativas foram analisadas e as categorias seguintes puderam ser elaboradas, a fim de facilitar a compreensão e apreensão dos conteúdos relacionados ao adoecimento e sobrevivência ao câncer de mama.

CONTANDO A HISTÓRIA DO ADOECIMENTO

\section{O início da história}

\section{O diagnóstico}


O diagnóstico de câncer é vivido, na maioria das vezes como um momento de crise, tendo um efeito devastador na vida da pessoa que o recebe, podendo, inclusive, desencadear no indivíduo reações emocionais como medo, ansiedade e depressão, e sentimentos como impotência, desesperança, temor e apreensão, causando um sofrimento intenso capaz de resultar em desorganização psíquica, consequências estas que vão depender da localização da doença, do estágio em que ela se encontra e do tratamento adotado (CARVALHO, 2002; PENNA, 2004; VENÂNCIO, 2005; SILVA, 2008; SILVA; AQUINO; SANTOS, 2008; SILVA, 2005).

A reação de choque e o forte impacto emocional, experimentados a partir do diagnóstico de câncer, podem ser percebidos nos relatos das participantes deste estudo, ao se depararem com a realidade que Ihes foi imposta pela situação da doença.

“... O mundo virou né, desabou tudo né... você não imagina como que é o câncer, como que é esse tratamento... você leva um choque de tudo." (Juliana)

“... Ah não acredito que eu to com câncer com dois filhos pequenos, dois filhos adolescentes, meu marido não mora aqui e como é que eu faço". (Marina)

“Quando o médico começou a falar a gente leva um baque né..." (Rosangela)

"... É um choque na hora que a gente pega o resultado e vê que é maligno. Mas eu também tenho muita fé e aí tentei ser forte..." (Cleusa)

A partir do diagnóstico de câncer a pessoa vê sua vida tomar um rumo diferente do que poderia imaginar, muitas vezes ocorrendo alterações 
significativas nas diversas esferas da vida como o trabalho, o lazer, a família, (BLOOM, 2002; SALES et al., 2001; VENÂNCIO, 2005), e também consequências em seu cotidiano, nas relações com as pessoas do seu contexto social (BERGAMASCO; ANGELO, 2001).

Estudos indicam que a fase de comunicação do diagnóstico é um momento de fundamental importância para que se estabeleça uma relação de confiança entre o médico e a paciente (ROSSI; SANTOS, 2003). A forma como a notícia é dada, pode influenciar na apresentação ou na redução de alguns sentimentos que podem vir a ser experimentados pela mulher de forma negativa (VIEIRA; LOPES; SHIMO, 2007).

Assim como Juliana, Clarita sofre um grande impacto ao receber o diagnóstico de câncer e fala de sua insatisfação com relação ao modo como esta informação lhe foi dada.

“... Eu levei tanto choque, tanto choque que eu fiquei sentindo mal, eu nunca senti tão mal igual quando o médico me passou que eu tava com câncer, ele falou na lata assim. Na tua cabeça você ta cheia de saúde e o médico vem e solta aquela bomba em cima de você... é muito despreparo, se eu tivesse no lugar dele (referindo-se aos médicos) eu trabalhava primeiro a pessoa, com a cabeça da pessoa..." (Clarita)

A postura de acolhimento do médico associa-se, na maioria das vezes, ao grau de satisfação da paciente com relação à forma como o diagnóstico é comunicado (ROSSI; SANTOS, 2003).

Diante do diagnóstico de uma doença maligna como o câncer, a pessoa sente como se tivesse perdido o controle sobre a sua vida, o que causa grande 
sofrimento e faz surgir sentimentos de impotência, angústia, isolamento. raiva, medo, pena de si mesmo (MUNIZ; ZAGO; SCHWARTZ, 2009).

$\mathrm{Na}$ narrativa de Velma, ela nos mostra o quanto ficou desesperada diante do diagnóstico, tentando por fim à própria vida.

“... Quando eu descobri foi difícil, eu tentei suicídio, certo, não queria operar, eu pensei que eu tinha muito pouco tempo, não queria fazer tratamento...” (Velma)

Durante toda a vivência do adoecimento de câncer os sentimentos mudam muito. Há um aprendizado muito grande no sentido de buscar uma organização de sua vida, com o intuito de se saber o que vai ser feito e, então, não perder o controle da situação (BERGAMASCO; ANGELO, 2001).

O relato de Anali é convergente com esses achados, sobre as mudanças de sentimentos durante a experiência do adoecimento. Ela nos mostra em seu relato como reagiu ao tomar conhecimento do seu diagnóstico e como conseguiu aceitar a situação após algum tempo e as mudanças que acompanham esses novos eventos na vida da pessoa.

"Primeiro não, você não aceita, porque com o câncer é assim, você não tem dor, você não sente nada, de repente vem o médico e fala 'você tá com câncer' e você achava que era super saudável, que tinha tudo... Aí depois vem a aceitação, você precisa aceitar e muda, muda bastante coisa na vida da gente". (Anali)

Cristine passou por dois diagnósticos de câncer de mama e fala sobre como os vivenciou de forma diferente. 
“O câncer veio em 2002, mas como ele veio de uma forma bem suave, eu falo, eu não... eu falava assim 'nossa nem parece que eu tive câncer'... Em 2002 eu não mudei nada, porque na verdade eu não senti o impacto, na mesma semana eu tive alta e já tava trabalhando e eu continuei a mesma coisa." (Cristine referindo-se ao primeiro diagnóstico)

"Quando o câncer voltou em 2006 aí mudou tudo porque aí eu tive a questão do visual, do físico, eu fiquei sem mama né, com uma marca, eu tenho uma cicatriz muito grande no corpo..." (Cristine referindo-se ao segundo diagnóstico)

O vislumbre da morte é outro aspecto muito evidente em estudos com pacientes que receberam diagnóstico de câncer de mama (ROSSI; SANTOS, 2003). Corroborando com estes estudos, Florentina conta que teve um susto muito grande ao saber de seu diagnóstico e, em um primeiro momento, pensou que ia morrer.

“Então eu fui fazer o exame e eu tava com um câncer pior que o da minha mãe... Na hora que a gente fica sabendo a gente leva um susto muito grande, você pensa no primeiro momento que vai morrer, você pensa muitas coisas assim, e depois aí eu acho que fui me acalmando e entendendo..." (Florentina)

O momento em que uma pessoa recebe um diagnóstico geralmente é decisivo, porque a partir de então, esta tem a possibilidade de reformular aspectos importantes de sua vida (RZEZNIK; DALL'AGNOL, 2000). 


\section{A trama da história}

\section{Ações de enfrentamento}

Muitas construções culturais acerca do diagnóstico da doença ainda fazem com que a mulher sinta que está recebendo uma sentença de morte. As representações associadas ao câncer são, na sua grande maioria, negativas. Por isso, é importante para a mulher sentir que há recursos e fontes de apoio disponíveis, que não a permitem desistir e, que torna mais possível, lidar com o processo de adoecimento (BERGAMASCO; ANGELO, 2001).

Nesta categoria, empregamos o que Little et al. (2002) em seu estudo, denominam "anchor points" ou pontos de apoio, também encontrados como fontes de apoio, que são as crenças, valores e/ou recursos utilizados pela pessoa que vivencia um adoecimento grave ou outra experiência extrema e que auxiliam a lidar com o rompimento de sua identidade pessoal.

Os pontos de apoio que estiveram presentes nas narrativas das participantes deste estudo foram: a família (filhos, irmãos, marido), Deus (espiritualidade/ fé), o trabalho e o apoio psicológico.

A família pode servir como fonte de apoio para o enfrentamento da doença e de suas conseqüências, uma vez que ela faz parte do contexto no qual a mulher que adoece está inserida. Podemos ver no relato de Lorena a importância que ela atribui a sua relação com a irmã, que serve como um ponto de apoio para lidar com o processo de adoecimento. 
“... Eu tive uma força muito grande da minha irmã... Ela me dava atenção e foi o meu suporte, o meu anjo de guarda... Então eu não posso dizer que eu fiz isso por mim sim, porque seria muito egoísta se eu não tivesse lutado por mim, mas que 50\% foi por ela, $50 \%$ pra cada uma, porque quando eu vi o olhinho dela ficar vermelho, eu falei 'você não vai chorar por mim desse jeito não, eu vou lutar, mas eu vou lutar mesmo...". (Lorena)

Assim como no relato de Lorena, Hélia também se utiliza da relação com o filho como ponto de apoio para enfrentar o adoecimento. Ela refere o desejo de vê-lo crescer, se formar e entrar numa faculdade.

"Fiz a cirurgia e não é fácil, vou te falar que não e fácil, e tentei fazer passo a passo, tudo o que eu tinha que fazer sem fugir um milímetro e graças a Deus tive assim, eu pensava mais por ele em vencer porque tinha 14 anos na época, então eu ainda queria vê-lo crescer, se formar, entrar numa faculdade...". (Hélia referindo-se ao filho).

Também para Marina e Velma a família aparece como uma das principais fontes de apoio utilizadas para lidar com o adoecimento.

"A hora que você pensa que você tem família, que você tem filho, que tão aí, que você não pode morrer agora..." (Marina)

"Na parte de família, graças a Deus, minha família me ajudou muito bem..."(Velma).

Muitas mudanças podem ocorrer na rotina quando uma pessoa na família adoece de câncer. Estas mudanças precisam ser incorporadas por todos os membros da família, podendo estes se tornar importantes pontos de apoio (BIFFI; MAMEDE, 2004) 
A religiosidade e/ou espiritualidade, enquanto fonte de apoio, tem sido estudada por diversos pesquisadores, que constatam sua influência sobre a saúde. Nas pessoas que adoecem, a espiritualidade pode favorecer o processo de aceitação da doença e a reabilitação (MARQUES, 2003), como vemos com pacientes de câncer ao lidarem com as dificuldades físicas e psicológicas resultantes do diagnóstico e tratamento (MERAVIGLIA, 2006).

Segundo Gall e Cornblat (2002), a valorização de aspectos da espiritualidade, como propósito e significado da vida, preces e perspectiva espiritual, é benéfica e diminui o impacto do câncer. Alguns estudos mostraram a importância da religião/espiritualidade e, mais especificamente, da prece no comportamento adotado pelos pacientes com câncer, destacando que muitos desses pacientes tornam-se mais religiosos depois de um diagnóstico de neoplasia maligna (DANN; MERTENS, 2004).

Deus (espiritualidade) e a família foram os pontos de apoio que Rosangela utilizou para lidar com o processo do adoecimento, como podemos ver em seu relato.

“... Daí vem todo o processo, ah eu não sei explicar... eu tenho muita fé em Deus, apoio da família demais..." (Rosangela)

A presença do parceiro é altamente significativa no processo de reabilitação de um adoecimento por câncer. Muitas vezes é ele que vai servir como ponto de apoio, sendo, portanto, importante que esteja apto a oferecer afeto, fazendo com que a mulher se sinta acolhida e compreendida (BIFFI; MAMEDE, 2004). 
Cristine fala da importância de sua relação com a filha e com o marido para lidar com o adoecimento.

"Eu e a minha filha a gente tem um amor assim, uma relação afetiva, e ela me ajudou muito porque no momento que eu tive o câncer ela tava em casa fazendo cursinho, então ela que me ajudou, me deu banho, então assim isso nos uniu muito né. E o marido também né, que assim ele foi muito importante, é uma pessoa simples, sempre foi muito simples, ele é uma pessoa muito do bem..." (Cristine)

Silene e Juliana também encontraram apoiou em suas relações com os maridos para lidarem com o processo do adoecimento.

"Eu queria viver por causa do meu marido, eu me preocupava muito com ele por ele ter esse problema de memória e de não lembrar das coisas, então se eu fosse primeiro que ele eu não sei o que seria dele."(Silene)

"Então eu acho, se você tem câncer, a primeira coisa é o marido, não é o seu pai, sua mãe, seu irmão, seu tio, é o marido, se realmente você quer ficar com ele, porque no momento que você se esconder dele seu casamento já era." (Juliana)

Juliana também refere ter encontrado apoio no REMA (serviço de assistência à mulher com câncer e familiares).

"No REMA é um lugar assim que, como se diz tem profissionais, tem fisioterapeuta, tem terapeuta ocupacional, tem psicólogo, tem enfermeira, tem nutricionista, é um conjunto que tem ali dentro que você não vai achar... E a terapia em grupo que ajuda bastante que eu acho assim, você já tem uma idade, você não tá trabalhando, já tá frustrada dentro de casa e ainda você tem o câncer então eu acho assim, só pelo fato 
de você procurar algum lugar pra te ajudar já é meio caminho andado, porque se você não procura você cai, você cai." (Juliana)

Anali e Clarita se utilizaram de apoio psicológico recebido para lidar com 0 adoecimento.

"Eu tive que procurar uma psicóloga, nesse mesmo dia porque eu falei assim... aí sabe envolve família, família começa ligar, um começa 'ah não sei o que’ né, aí eu peguei e falei 'ai meu Deus do céu', aí começa a vir muita gente falar na tua cabeça, aí eu falei 'não vou agüentar'. Aí eu liguei pra uma psicóloga e ela falou 'vem aqui agora', e ela me ajudou muito, muito, muito... aí foi um ajuda assim primordial, eu acho." (Anali)

“... Eu acho que a coisa mais certa que tem é quando a gente passa pelo psicólogo que tenta orientar a gente, fala com a gente, a gente não escuta nada porque a gente já ta na pior mesmo, mas aquilo ali já é uma ajuda boa pra gente, é um meio..." (Clarita)

Estudos mostram que pacientes que participam de atendimento psicológico possuem melhor ajustamento à doença, redução dos distúrbios emocionais (como ansiedade e depressão), melhor adesão ao tratamento e diminuição dos sintomas adversos associados ao câncer e ao tratamento, podendo até obter um aumento no tempo de sobrevida (VENÂNCIO, 2005).

Florentina encontra no trabalho e nas relações de amizade decorrentes deste, o apoio necessário para lidar com o rompimento da continuidade da identidade frente ao adoecimento. 
"Eu gosto muito de trabalhar, eu gosto muito daqui (fala de seu trabalho), aqui eles são uma família pra mim, que é a extensão da minha casa." (Florentina)

Corroborando com outros estudos, as falas das participantes vêm a confirmar a importância do apoio de outras pessoas no estabelecimento de novas perspectivas para a mulher que vivencia o câncer de mama, fortalecendo a autoconfiança e possibilitando um melhor enfrentamento das situações envolvidas. Ao perceber esse apoio a mulher pode tornar-se forte e capaz de buscar uma nova reintegração do "self"; pode encontrar uma boa qualidade de vida, um começar de novo, apesar do câncer (ARAUJO; FERNANDES, 2008; HOFFMANN; MULLER; FRASSON, 2006).

\section{Atribuindo um significado à doença}

O câncer de mama leva à desestabilização da vida da mulher, trazendo para sua convivência a incerteza da vida, a possibilidade de recorrência da doença e a dúvida quanto ao sucesso do tratamento. Durante as diferentes etapas de sua doença, a mulher busca atribuir algum tipo de significado àquilo que está acontecendo com ela (ALMEIDA et al., 2001).

Ser diagnosticado com câncer corresponde, para o paciente, na maioria das vezes, a uma experiência dramática, inesperada e chocante, colocando-o frente a uma realidade que até então parecia distante e diante do mais primitivo de seus medos - o medo da morte (BARBOSA, 2003; DUARTE, ANDRADE, 2003; KÓVACS, AMORIM, FILHO \& SGORLON, 1998; SILVA, 2005). Tal medo é decorrente de uma representação da doença, que fora culturalmente 
construída de que o câncer leva necessariamente à morte, pelo fato das pessoas acometidas de câncer, na grande maioria das vezes, receberem o diagnóstico em fase já avançada da doença, quando não havia mais perspectiva de controle ou remissão (PENNA, 2004; SILVA, AQUINO; SANTOS, 2008).

Segundo Barbosa, Francisco e Efken (2007), em pacientes oncológicos, a questão que se estabelece não é do medo de "simplesmente morrer", mas sim o de "morrer de câncer", dado o seu estigma e representações negativas construídas ao longo dos séculos. A doença vem sempre acompanhada de sentimentos como angústia e ansiedade e causa consternação tanto nos pacientes quanto em seus familiares. Essa associação do câncer a uma sentença de morte pode ser vista nos relatos a seguir.

"Foi uma sentença de morte, eu acho que pra todo mundo é... Você perde o chão, perde tudo, fica num desespero que você perde a referência da sua pessoa, então é um negócio muito duro, só quem passou pode saber.” (Hélia)

"Porque é uma doença que é a mesma coisa que falar pra você assim ó uma sentença de morte, uma sentença de morte com prazo curto, que se fosse uma sentença de morte com prazo longo ainda você ficava satisfeita... Eu acho que a pior doença que existe é o câncer..." (Clarita)

“É, eu sempre encarei, ouvi falar que essa doença mata, que é perigosa..." (Cleusa)

"Eu pensava que mesmo eu fazendo o tratamento eu ia morrer dali pouco tempo..." (Velma). 
Fica evidente o quanto a experiência do adoecimento por câncer é assustadora para essas mulheres, que se sentem ameaçadas e perdem as referências de que dispunham anteriormente.

Contrapondo-se às associações negativas, na narrativa de Cristine o câncer ganha outro significado. O adoecimento, neste caso, é compreendido como uma oportunidade para mudar de vida, permitindo a percepção de alguns comportamentos, que então foram vistos como inadequados.

\footnotetext{
"Me deu uma nova chance de mudar de vida, não que hoje eu sou a sétima maravilha do mundo, eu ainda tenho aliás todos os defeitos que eu tinha antes, só que hoje assim eu sei que eu tenho mais equilíbrio né para lidar com a situação...” (Cristine)
}

No relato de Lorena, vemos que o significado do adoecimento em sua vida é ilustrado por um impasse: escolher entre enfrentar ou não o dragão, que é como ela visualiza o câncer. Ela mostra então que decide enfrentar, agarrase à vida, mantendo acesa a centelha de esperança na possibilidade de cura. Essa estratégia de enfrentamento é extremamente importante para a manutenção da autoestima e do nível de motivação para o engajamento no tratamento (ROSSI; SANTOS, 2003).

“... Eu me considero assim, sofri como todo mundo sofre, ninguém é mais privilegiado do que o outro, simplesmente você tem que ter uma consciência de que é um dragão, agora você escolhe ou você bate de frente com ele ou você deixa ele passar por cima de você, das duas uma ou você bate de frente ou deixa ele passar. Mas eu não deixei, eu fui bater de frente com ele..." (Lorena) 
O câncer é uma doença ainda carregada de um sentido muito negativo. Além disso, em nossa sociedade, o câncer adquiriu significados relacionados à culpa, punição, deterioração, dor e morte, agravando o sofrimento psicológico das doentes (GOMES; SKABA; VIEIRA, 2002; SILVA, 2008). Estudos mostram que, muitos anos atrás, o câncer era considerado um castigo, através do qual o doente poderia alcançar sua redenção, a libertação dos pecados caso conseguisse suportar com resignação o sofrimento causado pela doença (SILVA, 2008).

Na narrativa de Clarita percebemos o sentido punitivo que ela atribui ao câncer, falando do não merecimento desta experiência.

“... Eu achei que isso aí não poderia acontecer comigo, porque eu nunca desejei mal pra ninguém, eu nunca fiz mal pra ninguém, eu sempre fui uma pessoa muito boa. Então, eu achei que isso podia acontecer com qualquer pessoa menos comigo, eu não merecia isso que eu tava passando. Eu me senti assim na hora da morte sem merecer e acontecendo o pior comigo, foi terrível pra mim. Então, não adianta nada a gente ser boazinha, não adianta nada a gente ser honesta, não adianta nada a gente fazer tudo certo na vida, porque o pior acontece com a gente." (Clarita)

O câncer de mama e seu tratamento trazem repercussões importantes no que se refere à identidade feminina, autoestima e imagem corporal daquelas que recebem o diagnóstico da doença. Além da perda da mama, ou parte dela, causando desfiguração do corpo, os tratamentos complementares podem impor dores insuportáveis, a perda dos cabelos, a parada ou irregularidade da menstruação e a infertilidade (MAKLUF; DIAS; BARRA, 2006; SILVA, 2008). Alguns destes e também outros aspectos podem ser vistos nos relatos a seguir. 
“... A doença não é tão difícil, o difícil é o tratamento, entendeu? Judia muito, eu ficava internada, eu não comia, eu não podia ficar na minha casa, entendeu, não podia ver cheiro de nada... a quimio... a radio só queimou bastante, o mais difícil foi a quimio, só de lembrar é horrível..." (Velma)

“... Dá náusea, dá onda de calor, quebra as unhas, cai o cabelo, a unha do pé fica feia, as pernas um dia tem cabelo, no outro dia não tem, a sobrancelha fica falha..." (Lorena)

“... O tratamento é um tratamento que judia muito, os remédio é muito difícil, certo, você sente mal mesmo né, então se falar que não sente é mentira... Eu fiz a radio, a radio queima, mais queima muito... Minha filha punha um chá de camomila na geladeira $e$ pegava uma fralda e punha, a fralda do chá gelado, punha assim em cima a fralda ia fumaçando, fumaçando, quando vê a fralda tava sequinha de tão quente que tava $o$ meu peito. O meu peito assim a pele dele saiu tudo assim, ficou na carne viva..." (Clarita)

"Você tem que vencer várias batalhas quando você descobre que você tem isso, é.... todo mundo acha que é fácil ficar careca, é difícil, ninguém fala 'como você está linda careca', fala assim simplesmente 'você tá linda', linda com dó né, dó de você, 'ah você tá linda, sua cabeça é perfeita', mas você sabe que no íntimo não é isso né, e eu fiz a primeira quimio passou 20 dias o meu cabelo começou a cair e no dia que eu fiz a quimio eu fiquei pensando como que ia ser..." (Juliana)

"Aí veio a fase depois da cirurgia, que é uma cirurgia chata, pegou um corte do bico do seio veio até aqui embaixo que fez o esvaziamento de axila também, pra pevenir, então veio até aqui debaixo um corte enorme. Aí tem que ficar com dreno, depois tira dreno, aí forma líquido outra vez, a gente tem que vir aqui umas vezes pra aspirar, sabe, mas... Aí veio a pior fase né, que é a quimio, a quimio é uma barra, nossa senhora fico 
vendo esses pacientes carequinhas dá até um mal estar, porque eu fiquei sem nenhum fio de cabelo, caiu tudo, sobrancelha, cílio, caiu tudo, tudo, tudo, tudo." (Silene)

Estes relatos vêm a corroborar com outros estudos que afirmam sobre as lembranças do tratamento ainda se mostrarem bastantes presentes, mesmo depois de decorrido certo tempo, por volta de cinco anos desde o diagnóstico, como é o caso das participantes do estudo (LANZA, 2008).

Mesmo depois de concluído o tratamento, quando a pessoa se encontra sem os sintomas da doença e pode ser considerada sobrevivente, ainda assim continua a questionar porque isso lhe aconteceu e o que levou ao acometimento por essa doença (TAYLOR, 2003). De um modo geral, as pessoas não são preparadas para perder a identidade e lidar com experiências de adoecimento grave (ARAUJO; FERNANDES, 2008).

Em seu relato, Clarita mostra não ter compreendido porque teve o câncer. Ela acreditava que apenas pessoas que faziam mal para os outros é que tinham essa doença, sente-se inconformada.

"Meu sogro morreu de câncer no estômago, meu sogro tinha matado um homem e tudo, eu falava pro meu marido, pai da minha filha, 'eu vejo que quem tem câncer é só gente que foi muito ruim pros outros, então tem essa doença e fica sofrendo, sofrendo pra morrer', igual meu sogro que levou três anos pra morrer, queria morrer e não morria e sofrendo, sofrendo, e tomando morfina e com dor e tudo, passou a não falar, passou a não alimentar, só alimentava por sonda. Então eu falava pro meu marido 'toda pessoa que é muito ruim sofre muito pra morrer'. Depois quando aconteceu comigo eu falei 'quer saber de uma coisa, eu nunca fui ruim e tá acontecendo, agora eu tenho que mudar. Porque eu nunca desejei mal pra ninguém, nunca roubei, nunca matei, nunca fiz nada errado e tá acontecendo comigo'. Então já não é mais como eu penso a vida, que a vida eu penso assim, se você planta o bem, você tem que colher o bem, se 
planta o mal você tem que colher o mal. Eu só plantei o bem e to colhendo o mal." (Clarita)

Cristine faz o processo de buscar em sua história de vida, uma explicação para o surgimento da doença. Ela retoma algumas questões emocionais vividas no passado e as reconsidera.

\begin{abstract}
"As pessoas que tem questões emocionais mal resolvidas, então eu acho que eu sempre tive isso, problema de relacionamento com a minha mãe... Eu acredito que isso tenha tido influência porque eu sempre fui muito nervosa, muito tensa, aquela coisa parece de você não estar bem em lugar nenhum... Qualquer coisa eu já me irritava, não tinha horário pra comer, não tinha horário pra sair do serviço, levava uma vida muito... As doenças elas tem aparecido muito por conta disso, a gente acaba assumindo coisas que não dá conta, mas quer assumir. E aí o câncer veio...” (Cristine)
\end{abstract}

Juliana também mostra em sua narrativa, a elaboração de alguns acontecimentos de sua vida, na busca pela compreensão da causa da doença. Em um movimento reflexivo ela relembra algumas experiências como perdas e separações, o adoecimento, e relaciona o câncer a uma soma de eventos que ocorreram em sua vida (ausência dos pais, perda do emprego).

“... Eu queria descobrir por que eu tive o câncer. Todo mundo fala assim 'ah é hereditário', mas ao mesmo tempo eu tenho certeza que não é isso... Eu acho que são coisas que vem vindo da vida da gente, pra mim eu acho que foi né, foi coisinhas que veio caminhando assim e juntou, só que uma hora teve que explodir pra alguma coisa, não foi um enfarte, não foi um derrame, não foi isso, foi o câncer.... Eu tinha dez anos quando meu pai faleceu... A minha mãe nunca morou comigo, o meu pai nunca morou comigo, a gente sempre morou separado. Eu sentia muito a ausência deles... morava 
com as minhas irmãs... Acho que a história começa aí da minha vida pra eu ter um câncer hoje, quanto foi difícil eu superar esse negócio, coisas assim que ninguém entendia porque eu chorava, porque eu às vezes... eu tentei sobreviver nessa época..." (Juliana)

Juliana se percebe como sobrevivente de várias situações difíceis que vivenciou. Para uma pessoa, o significado de determinada experiência surge a partir de como ela se define no presente em relação a outras experiências vividas ao longo da vida. A compreensão das mulheres e suas percepções frente ao adoecimento por câncer sofrem influência das interações onde se formam, transformam e sustentam os conceitos que elas têm delas mesmas e do câncer (ARAUJO; FERNANDES, 2008).

\section{Transformação - novas identidades}

De um modo geral, as pessoas nunca esperam adoecer ou sofrer acidentes que possam interferir de forma drástica no curso de suas vidas. Todavia, a qualquer momento da vida podem deparar-se com mudanças difíceis e dolorosas na saúde que alteram o curso de vida de maneira inesperada (RZEZNIK; DALL'ÁGNOL, 2000).

Certos eventos e experiências, como o adoecimento por uma doença grave, são compreendidos como ocasiões para prováveis mudanças na identidade da pessoa (CROSSLEY, 2000; FRANK, 1993), induzindo-a a buscar o autoconhecimento, a avaliar sua postura frente a determinadas situações que a vida lhe apresenta, a repensar alguns valores e princípios que estiveram presentes em suas vidas (RZEZNIK, 2001). 
Muitas vezes a vivência de uma doença como o câncer pode estar associada a indícios de morte, mas pode ser também um momento de se reformular a vida (ARAUJO; FERNANDES, 2008). O câncer de mama precisa ser considerado em toda a sua amplitude, pois traz mudanças efetivas na vida da mulher que não tem apenas o seu corpo, símbolo de feminilidade, modificado, mas também a sua imagem corporal, sua identidade e diferentes aspectos da sua vida social e afetiva (VENÂNCIO, 2005; VIEIRA; LOPES, SHIMO, 2007).

Terminado o tratamento, as participantes avaliam a experiência de ter tido câncer de mama e de ter passado por um tratamento invasivo e doloroso, visualizando as mudanças positivas e negativas em suas vidas.

A seguir, apresentamos trechos das narrativas que mostram algumas mudanças ocorridas na vida das mulheres sobreviventes do câncer de mama.

Clarita relata mudanças ocorridas em sua vida e em sua identidade (primeiro trecho) com a experiência do adoecimento, vistas por ela como negativas e justifica tais mudanças (segundo trecho):

"Hoje em dia eu não tenho princípio nenhum, hoje em dia o meu princípio sou eu mesma, eu quero agradar eu mesma, eu quero viver eu mesma... Larguei do meu marido de 70 anos, arrumei um rapazinho novinho, me interessa que eu to bem... Eu vivia em função da minha filha, hoje eu falo pra ela 'você tem que viver a sua vida'. Eu era muito mais meiga, mais atenciosa, mais carinhosa..." (Clarita)

"Eu mudei muito, a doença me mudou muito... Então já não é mais como eu penso a vida, que a vida eu penso assim, se você planta o bem, você tem que colher o bem, se planta o mal você tem que colher o mal. Eu só plantei o bem e to colhendo o mal, aí eu 
já mudo de vida, certo? Aí eu vou plantar do jeito que colho. Aí eu mudei a minha cabeça." (Clarita)

Ao receber o diagnóstico de câncer, a mulher se confronta com alterações em sua vida que transformaram definitivamente sua identidade social de pessoa saudável para uma identidade de doente (MUNIZ; ZAGO; SCHWARTZ, 2009). A experiência do adoecimento induz à consciência da necessidade de modificar determinados hábitos ou comportamentos, levando, em alguns casos, a uma valorização da vida e do cuidado consigo mesma; a mulher então se apresenta com novo self (ARAUJO; FERNANDES, 2008).

Veit, Barros e Chwartzmann (1998) afirmam que mesmo em situações de cura, diante do conhecimento da gravidade da doença, ocorre um repensar sobre a vida, que pode dar início à reconstrução de valores, com a revisão de padrões previamente estabelecidos e a descoberta de potenciais inatos, levando ao enriquecimento interior.

Cristine refere que a experiência do adoecimento proporcionou-Ihe uma reflexão de vida e que a partir desta reflexão ela obteve uma mudança interna, em sua identidade pessoal. Tal experiência também contribuiu para que Cristine adquirisse equilíbrio e tolerância.

“... Eu fiquei um tempo afastada (do trabalho), aí eu comecei a fazer uma reflexão de vida... Eu comecei a perceber que eu tinha que mudar por dentro, que eu não ia sobreviver se eu não tivesse mudança interna, mental, espiritual, então a religião é um suporte fundamental... eu fui fazendo estas mudanças e isso veio fazer uma transformação na minha vida... Hoje eu tenho a questão da tolerância, se eu vejo que eu to brava eu calo, coisa que eu não sabia, eu tinha que brigar... Hoje eu sei que eu tenho mais equilíbrio..." (Cristine) 
O reconhecimento de aspectos positivos em uma experiência tão dolorosa como o câncer de mama e seu tratamento mostra a existência de bons recursos adaptativos e de enfrentamento (ROSSI; SANTOS, 2003). Cristine e Anali passam a compreender e a considerar seus próprios limites a partir da experiência do adoecimento/sobrevivência. Cristine fala do crescimento alcançado.

"Hoje eu tenho limite, se eu to com sono eu atraso uns minutinhos, hoje eu me permito perder a hora, me permito sair, me permito comprar algumas coisas, então a gente vai trabalhando isso. Foi bom o resultado final, nossa, cresci demais, muito." (Cristine)

"De primeiro eu ia gripada sabe, eu ia com corpo doendo, mas agora eu não vou mais não, se eu não to bem eu não vou. Uma coisa que eu aprendi, a ver o meu limite..." (Anali referindo-se ao trabalho)

"Muda muito a vida da gente, uma parte assim às vezes muda pra melhor né... Assim eu era uma pessoa que não gostava de ir em hospital, não gostava de ir em lar, não gostava de ir em creche, hoje eu gosto, participo, entendeu... melhorou mais assim... melhorou... antigamente eu acho que eu pensava que ia acontecer com todo mundo menos comigo, hoje eu sei que acontece com todo mundo." (Velma)

Podemos perceber no relato de Velma que a aceitação da doença veio com o tempo e que ela consegue reconhecer aspectos positivos da experiência do adoecimento, apesar de inicialmente, ao momento do diagnóstico, ter pensado que morreria logo, como vimos na primeira categoria. 
Para algumas mulheres a doença possibilitou que passassem a ver a vida com outros olhos, isto é, possibilitou re-significar o viver (MUNIZ; ZAGO; SCHWARTZ, 2009).

Marina fala sobre seu modo de ver a vida, após a experiência do adoecimento/sobrevivência.

“... Eu acho que você vê a vida de um outro lado, você vê a vida agora e você fala 'gente, vamos aproveitar, vamos aproveitar que o negócio tai... Você vê de uma outra forma a vida"'.(Marina).

Nos relatos que se seguem, Rosangela e Juliana referem mudanças em seus valores a partir da experiência de adoecimento/sobrevivência.

“... Você dá mais valor, você não faz tanta questão das coisas sabe, não faz mais questão assim de coisas banais, de coisa boba, que tem pessoas que por pouca coisa faz o diabo acontecer, não é por aí né, você tem que pensar, não leva a vida...a gente leva a vida mais normal, não faço tanta questão sabe, muda os valores, coisa que tinha valor passa a não ter, entendeu?" (Rosangela)

"Se hoje eu tenho uma vida melhor, se hoje eu sei o quê eu quero, não é que antes a gente não sabia, mas to falando agora a gente sabe dar outros valores né e sabe se cuidar melhor." (Juliana)

Florentina vivencia a perda do filho juntamente ao processo de adoecimento. Sobrevivendo a sucessivas experiências extremas, ela conta sobre as mudanças ocorridas em sua identidade e utiliza-se da experiência do adoecimento para ajudar outras pessoas. 
"Mudei muito, você fica mais sensível, mais humana, mais voltada ao ser humano, mais cuidadosa, você tem mais vontade de viver, você presta atenção em coisas pequenas que te fazem feliz, não é, mudou bastante." (Florentina)

“Quando alguém chega e me diz 'ah eu to com câncer' eu falo 'levanta a cabeça, pensa em mim, pensa em outras pessoas que foram melhor do que eu né... Eu digo pra todo mundo que está em tratamento, a primeira coisa é procurar se informar com psicólogo, psiquiatra, com o enfermeiro, com o médico, saber bastante." (Florentina)

Silene refere ter mudado com o adoecimento, passando a priorizar suas vontades.

"Imagina e não sou mais como eu era de jeito nenhum, a gente muda... eu vou fazer aquilo que eu tenho vontade, eu não vou fazer uma coisa que ta me contrariando..." (Silene)

Apesar de Lorena sentir-se fortalecida e vitoriosa ao final do tratamento, como podemos ver em um trecho apresentado de sua narrativa na última categoria desta análise, a mesma refere não ter mudado com o adoecimento.

"Eu nunca achei que eu fui vítima, nunca achei que eu sou infeliz, briguei pelos meus direitos lá fora, não deixei de brigar pelos meus direitos... quer dizer, é a mesma Lorena de antes e agora..." (Lorena) 
Muitas pessoas acometidas por uma doença grave mostram a capacidade de extrair do sofrimento vivido, algum benefício, como nos trechos acima apresentados. Esta afirmação vem de encontro com os estudos de Frankl (1991), quando este refere que também podemos encontrar sentido na vida quando nos confrontamos com uma situação sem esperança, quando enfrentamos uma fatalidade que não pode ser mudada. Segundo o autor, o que o ser humano tem de mais elevado é o potencial de transformar uma tragédia pessoal num triunfo, em converter sofrimento em conquista humana.

Dificilmente a mulher que passa pela experiência do câncer de mama retoma sua vida nos moldes de como ela seguia antes. As seqüelas existem porque há uma mudança na identidade, já que a autoimagem não é mais a mesma e a forma como entendem, sentem e interpretam o mundo também mudou (DUARTE; ANDRADE, 2003).

Ao buscar novas perspectivas de vida, a mulher ultrapassa os limites da doença. Reintegra, portanto, sua identidade dentro de um conceito novo de si mesma, formulando e reformulando um novo self (ARAUJO; FERNANDES, 2008).

\section{O desfecho da história}

\section{Retomando a vida}

O câncer é uma doença que ameaça o sentido de integridade da pessoa. Algumas pessoas que sobreviveram a experiências extremas, como o câncer, parecem reconstruir suas identidades de forma que acomodam a experiência e suas seqüelas - ou seja, retomam uma versão de suas vidas 
anteriores, com novos pensamentos e dentro do contexto de suas personificações mudadas.

Ao receber o diagnóstico de câncer de mama, a mulher vivencia a expectativa de um futuro incerto, de um caminho de grandes dificuldades, e também o medo da morte e da mutilação. É um processo permeado por sentimentos contraditórios e intensos, nos quais o medo, a raiva, a incerteza e até mesmo a aceitação passam a fazer parte do seu dia-a-dia (ARAUJO; FERNANDES, 2008).

No relato de Hélia, vemos que ela acomoda a experiência do adoecimento, reconstrói sua identidade que havia sido rompida e mostra gratidão por tudo ter dado certo.

"E graças a Deus eu acho que eu fui uma pessoa feliz, fui, porque você vê mediante uma porção de relatos que a gente vê, eu passei por eles (refere-se aos tratamentos) e eu acho que sem muito assim, eu fui a que menos esforço fiz, porque Deus me permitiu que corresse tudo tranqüilo. Então eu só tenho a agradecer o que eu passei."(Hélia)

Apesar de ter presenciado a morte de duas primas com câncer, Florentina não pensou que o mesmo aconteceria com ela. Em sua narrativa, podemos perceber a aceitação da doença, e continuidade à vida com alegria, entusiasmo e apreciação.

“... Vim otimista, tenho muita fé em Deus, em Nossa Senhora, sempre fui muito católica, em nenhum momento eu me senti revoltada 'por que isso aconteceu comigo', nunca, jamais. Eu entendi que isso pode acontecer com qualquer pessoa..." (Florentina) 
"Mas sobre o câncer é importantíssimo dizer isso, que pra mim eu levantei a cabeça e não desisti, eu fui em frente, eu vi morrer duas sobrinhas na família, cuidei delas, ajudei elas até o fim... Mas em nenhum momento eu pensei ‘elas morreram, eu também vou morrer', não penso assim não, penso que ta tudo certo, que vai dar... Eu sou muito otimista, sou muito alegre, eu amo viver, eu amo as pessoas, eu amo trabalhar..." (Florentina)

O adoecer de câncer está, muitas vezes, relacionado a sentimentos negativos como depressão, raiva, tristeza, dor, desespero, bem como a sensação de que as pessoas não entendem o sofrimento pelo qual se está passando, o que aumenta a vivência da solidão (VIEIRA; LOPES, SHIMO, 2007).

Silene, após o adoecimento de câncer, vivenciou a morte do marido que estava doente. Ela sente-se sozinha e sem entusiasmo pela vida, diferente de Florentina, que também viveu a experiência do adoecimento e a morte de familiares próximos (filho, primas), mas manteve a apreciação pela vida.

"Então eu estou desse jeito, eu vou fazer aquilo que eu tenho vontade, que pra mim não tem mais nada, é só eu, não posso contar com ninguém, eu sou sozinha, então vou fazer aquilo que eu tenho vontade de fazer..." (Silene)

O diagnóstico, assim como as diferentes fases do tratamento, trazem importantes conseqüências para a vida das mulheres. As preocupações sobre como será a sua existência, após ter uma doença como o câncer, leva algumas mulheres a sentirem-se distantes da possibilidade de reordenar a vida (DUARTE; ANDRADE, 2003; MUNIZ; ZAGO; SCHWARTZ, 2009). 
Clarita relata a impossibilidade de dar continuidade à vida de modo semelhante ao anterior à doença, apesar de assim desejar. A experiência do adoecimento causou um rompimento em sua identidade, impedindo-a de recuperá-la. Ela se apresenta em sua narrativa sentindo-se inquieta e deslocada, atribuindo um significado positivo à vida antes da experiência do adoecimento e negativo, posterior à doença, adotando uma identidade de desencaixe.

\footnotetext{
"Eu mudei muito, eu era uma pessoa muito melhor eu acho... Às vezes eu até tento melhorar, mas não tem jeito... Eu tinha uma vontade de ser como eu era, mas eu não consigo, eu não consigo ser como eu era muito legal, mas muito legal mesmo, hoje eu não sou mais, não é porque eu não quero não, é porque minha cabeça mudou mesmo." (Clarita)
}

Cada pessoa tem o seu modo peculiar e único de vivenciar e de dar continuidade à vida após uma experiência extrema, como o adoecimento por uma doença grave.

\section{O significado da sobrevivência}

Sobreviver ao câncer remete a um estado ainda não muito reconhecido. $\mathrm{Na}$ maioria das vezes, espera-se que o sobrevivente aja dentro do contexto da normalidade, desconsiderando as tensões existenciais contínuas em sua identidade. Com vistas à cura, a nova etapa da vida ainda é um paradoxo. Se por um lado a pessoa tenta retomar sua vida e planejar o futuro, por outro teme o retorno da doença (MUNIZ; ZAGO; SCHWARTZ, 2009). 
Representações dominantes do câncer constituem desafios na busca de um sentido pessoal e individual da doença pelo sobrevivente (KAISER, 2008). As pessoas normalmente esperam ouvir "histórias boas", ou seja, histórias alegres, de pessoas que vivenciaram o câncer e sobreviveram. Na verdade, estas histórias são idealizadas e refletem aquilo que se deseja. Não necessariamente são boas histórias, pois para terem essa qualificação elas precisam fazer sentido mais que serem história de final feliz. Com relação à sobrevivência do câncer de mama, uma boa história seria então aquela em que, estivesse presente, o reconhecimento do papel do câncer na vida da mulher a longo prazo, assim como o medo da recorrência (FRANK, 1995).

Lorena refere o período do término do tratamento, o que implica em sua condição de sobrevivente e a construção do significado que esta nova condição tem para ela.

"Eu to terminando, então parece uma criança, pega o calendário, esse mês eu vou tomar pra tal mês, esse pra tal mês (referindo-se ao uso da medicação oral utilizada por um período de tempo médio de 60 meses)... Então é assim a contagem regressiva como se você tivesse para ganhar um troféu e já estivesse pra colocar as mãos nele... Me considero vencedora, fortalecida". (Lorena)

"O dia que ele me deu alta aqui eu falei 'acabou', aí eu caminhei no centro da cidade assim, olhei bem pros prédios mais altos e falei assim 'gente será que sou eu mesma?' você se pergunta isso, 'e to aqui desse jeito, andando? Viva?' Você sabe que acho que a emoção foi tão forte que ao invés deu pular como muita gente faz eu fiquei na sombra de dúvida. Aí fui pra casa, minha irmã falou assim 'terminou?', eu falei 'terminou'. Ela falou 'graças a Deus', eu falei 'graças a Deus'. Ela falou 'nossa, mas que graças a Deus mais seco', aí eu falei assim 'é, parece que o mundo caiu'. Ela falou 'o 
quê?', falei 'acho que ele desabou em cima de mim'... Ela falou 'mas em vez de você sem plena sexta-feira estar pulando de alegria você ta falando que o mundo caiu?'. Falei 'caiu, mas eu sobrevivi'. Simplesmente foi uma carga que saiu das minhas costas que eu me senti tão leve que nem eu tava acreditando." (Lorena)

Considerando-se uma vencedora, Lorena quase não acredita quando se vê livre do tratamento do câncer, em uma nova condição, de sobrevivente.

Marina se refere ao término do tratamento como um renascimento, um recomeço.

"Eu nasci de novo, uai, tem que comemorar, eu nasci de novo". (Marina)

A cura significa a recompensa do sofrimento causado pela doença. A passagem de um estado de doença à saúde, dá um novo sentido e reformula o comportamento da pessoa, alterando a sua perspectiva de como percebe o mundo e relaciona-se com ele.

Juliana fala da sua felicidade ao finalizar o tratamento do câncer, em ter superado esta experiência e ser uma sobrevivente. É como se ela tivesse ganhado na loteria.

"Então pra mim acho que assim ganhei na loteria... hoje eu sou muito feliz, eu tenho certeza que se vier o câncer de novo eu enfrento com a mesma coragem... Não sei se isso é felicidade ou seu não é, mas eu conheço o lado da felicidade sim, agora mais que nunca, então pra mim superei." (Juliana)

Embora as mulheres que passaram pelo câncer de mama possam planejar o futuro, buscando uma vida próxima àquela anterior à doença, ainda 
sim, vivem o paradoxo de serem sobreviventes. A sobrevivência em câncer deve ser compreendida levando-se em consideração a dúvida que decorre da ameaça de qualquer diagnóstico oncológico, a incerteza sobre a possibilidade de estar efetivamente curado (CLAYTON; MICHEL; BELYEA, 2006; RONSON; BODY, 2002; MUNIZ; ZAGO; SCHWARTZ, 2009).

Estas mulheres estão em processo de reconstrução de suas vidas e de construção de significados em torno da doença. Perspectivas sobre a sobrevivência podem mudar ao longo do tempo, ao sentirem-se mais distantes do tratamento, ou seja, se sentido curadas, ou perto de enfrentar uma possível recorrência (KAISER, 2008).

Florentina discorre sobre esta incerteza e medo vividos no período póstratamento.

"O primeiro ano a gente confia desconfiando, a gente fica com muito medo, precisei tomar um pouco de antidepressivo e remedinho pra dormir que eu não conseguia..." (Florentina)

Compreende-se que a concepção de cura para as mulheres do estudo está relacionada ao retorno às atividades e possibilidades futuras, é a busca por uma reconstrução da identidade, é ser uma sobrevivente do processo de adoecimento e tratamento. $O$ sentido de estar curada revela-se em suas novas significações, ao retomar o controle de sua vida.

Nesse sentido, a cura, a sobrevivência, é um modo de re-significar que foi sendo construído ao longo da trajetória de ser uma sobrevivente de câncer. 


\subsection{Análise global das narrativas}

Estudos realizados por Frank $(1995 ; 2012)$ sugerem formas pelas quais as histórias podem ser pensadas, refletidas, a fim de serem mais bem compreendidas. Apresentaremos aqui uma análise das histórias/narrativas de acordo com a tipologia de Frank (1995; 2012) envolvendo três tipos centrais, que são as narrativas de restituição, as narrativas de busca e as narrativas de caos. Segundo o autor, um tipo de narrativa é a história mais geral que pode ser reconhecida, subjacente à trama e tensões particulares.

Grande parte das narrativas apresentadas é considerada, de um modo geral, de restituição. Este tipo se move sobre três temas, começando com saúde, seguido do adoecimento e buscando um retorno à saúde. Em outras palavras, é quando alguém fica doente, é tratado, o tratamento eventualmente é um sucesso, e a pessoa se restabelece a, pelo menos, uma aproximação razoável da vida que tinha antes da doença.

Alguns detalhamentos aqui mencionados podem ser encontrados nas sínteses das histórias das participantes (em Apêndices).

A história de Anali como ela nos contou traz elementos sobre o seu adoecimento, o afastamento do trabalho, o tratamento, sua relação com o marido e seu retorno à atividade como professora. Ela conseguiu retomar sua vida, após o adoecimento, de forma que podemos então considerar sua história como uma narrativa de restituição, em que após a experiência da doença e do tratamento, ela se restabelece a uma condição semelhante à anterior ao seu diagnóstico. 
A narrativa de Lorena também pode ser considerada de restituição. Ela conta sua história começando pelo diagnóstico, fala sobre o tratamento permeado por complicações (efeitos colaterais) e retoma sua vida enfrentando o processo de adoecimento.

A história de Florentina traz elementos como o alcoolismo do marido, o adoecimento da mãe, o seu próprio adoecimento, a perda do filho mais novo e a perda de alguns familiares, primas, pai e avô. Apesar destas experiências tão dolorosas, ela consegue encontrar forças para superá-las e retoma sua vida. Florentina pode ser vista como uma sobrevivente de várias situações, não apenas sobrevivente de câncer.

Silene, assim como Florentina, sobrevive a várias situações de perda (perde o marido, a irmã e também a cachorrinha que era sua companheira) que aconteceram juntamente à experiência do adoecimento. Apesar de tudo, ela retoma sua vida.

As narrativas de Hélia, Marina e Rosangela também se enquadram em narrativas de restituição, em que todas vivenciaram o diagnóstico, o tratamento e deram continuidade as suas vidas, de modo semelhante ou próximo ao anterior ao adoecimento.

Thomas-Maclean (2004) considera ser mais apropriado chamar de narrativas de reconstrução as narrativas de mulheres que vivenciaram o câncer de mama e retomaram suas vidas após a doença. A autora faz esta afirmação considerando as mudanças ocorridas na identidade da mulher que vivencia o câncer de mama, incluindo mudanças físicas decorrentes do tratamento, sendo, portanto, muito difícil retomar a uma condição semelhante à anterior à doença. 
Em contraposição às narrativas de restituição encontra-se a narrativa de caos, e seu enredo refere-se a uma situação em que a pessoa imagina que nunca irá melhorar, ou seja, uma história de problemas intermináveis. Estas histórias, segundo Frank (2012), revelam vulnerabilidade, impotência, podendo até mesmo ser consideradas "anti-narrativas", por não apresentarem uma sequência específica de tempo e experiência, sendo difíceis de discernir, também denominadas narrativas de destroços. Em resumo, as narrativas de caos retratam pessoas "sugadas pela correnteza da doença", enquanto a narrativa de restituição retrata a doença como transitória.

Thomas-Maclean (2004) trabalhou com narrativas de mulheres sobreviventes ao câncer de mama, e seus estudos corroboram com os estudos de Frank (2012), no que diz respeito à presença da narrativa de caos, dentro de outras formas de narrativas de câncer de mama, proeminentemente em determinadas situações. Assim podemos ver que a narrativa de caos se manifesta dentro da narrativa de cada participante, sendo mais evidente no momento do diagnóstico, e ao vivenciar aspectos traumáticos do tratamento. Podemos ver no relato de Velma o modo como alguns aspectos do tratamento foram vivenciados por ela de modo conturbado.

“... Eu fazia radio, quimio, passava mal, às vezes eu saia tinha que ir pro hospital ficar internada...aí eu fiquei um ano assim, mal mesmo, passando mal foi um ano certinho. Aí depois terminou a quimio, terminou a radio, só que eu engordei demais, engordei 16 quilos não volto mais, meu cabelo caiu, eu era magrinha, e era difícil sabe..." (Velma)

A participante mostra sucessivas dificuldades vividas relacionadas ao tratamento e às conseqüências do mesmo. Para ela, não houve superação da 
experiência do adoecimento, nem o retomar de sua vida, até mesmo porque ela estava vivenciando a possibilidade de recorrência da doença.

"É difícil pra falar sobre isso (chora), agora tô fazendo exame e deu outro nódulo, agora tá mais difícil pra mim, eu to com medo de ter voltado... Eu to fazendo exame tem três meses, tem uma pasta já com o doutor, tem do meu ginecologista que já entreguei que é esses aí e pediu de novo, hoje passei no mastologista...três meses que eu to fazendo esse tanto de exame, é todo dia, de segunda a sexta... porque se fosse um médico só que resolvesse tudo, não, cada um é um médico, aí é mais difícil... Quando você acha que tá terminando, começar do zero de novo...é difícil." (Velma)

A possibilidade de recorrência também é apresentada contendo elementos caóticos em narrativas de câncer de mama (THOMAS-MACLEAN, 2004). Desde o diagnóstico, passando pelas dificuldades do tratamento, até a possibilidade de recorrência da doença, a narrativa de Velma traz elementos que a levam a ser considerada, de um modo geral, como uma narrativa de caos.

Cleusa passou por três diagnósticos diferentes de câncer e refere, em sua história, algumas dificuldades encontradas ao longo dessa experiência. Cleusa, assim como Velma, se vê frente à possível recorrência da doença.

“... A cirurgia foi muito traumatizante, é uma cirurgia de grande porte, eu tenho problema com anestesia, tive que muitas vezes voltar correndo pro hospital porque eu vomitava muito, desidratei... arrebentaram os pontos pelo esforço de vomitar, arrebentaram os pontos e tive muito sangramento" (Cleusa) 
"O médico falou eu tô com um cisto no fígado, mas ele disse que é uma coisinha tão pequena que não... o onco olhou a tomografia falou 'olha é uma coisinha muito pequena, a cada quatro meses vamos acompanhar'..." (Cleusa)

As narrativas de Cleusa e Velma são permeadas por momentos caóticos, principalmente enfatizados pelos momentos diagnósticos, procedimentos terapêuticos e possibilidade de recorrência da doença. Tais relatos mostram que a história de sobrevivência, ou seja, a identificação com o termo sobrevivente pode não fazer sentido para muitas pessoas que se encontram diante da possibilidade de recorrência da doença (KAISER, 2008).

O impacto de uma possível de recorrência é percebido quando a história da pessoa encontra dificuldade de seguir sua história; a recorrência significa um retorno ao caos, tanto dentro de um formato narrativo, como na vida da própria mulher.

O terceiro tipo, as narrativas de busca, são tão familiares em nossa cultura como as de restituição. Nas narrativas de busca as histórias seguem o formato da doença como um desafio e como um impulso para mudança, sendo, portanto, consideradas úteis (FRANK, 1995; 2012). O câncer nas narrativas de busca traz novos aspectos de si, fazendo com que a pessoa se torne melhor do que antes (FRANK, 1995; THOMAS-MACLEAN, 2004).

As narrativas de Cristine e Juliana podem ser vistas como narrativas de busca. As narrativas de busca são baseadas em uma implícita ou explícita metáfora de viagem, caminho ou percurso. São vistas, em termos de gênero, como romances, em que um personagem encontra uma série de dificuldades e ganha sabedoria para a superação destas. 
Juliana busca, a partir de seu processo de adoecimento, compreender o significado do câncer em sua vida. Ela reflete sobre vários eventos ocorridos em sua vida como a morte do pai, a separação de sua mãe, a demissão do emprego, e consegue, por meio da narração de sua história, dar a conhecer ao outro o processo vivido.

Cristine tenta compreender o significado da doença por meio de uma reflexão de vida, permeada pela experiência do adoecimento. Ela repensa sua relação com a mãe e as dificuldades de relacionamento no trabalho. A narrativa de busca então pode ser compreendida como um processo de apaziguamento dos conflitos vividos nesses dois contextos.

Acreditamos que em ambas narrativas, de Juliana e Cristine, as reflexões de vida apresentadas por elas podem ter sido facilitadas por processo psicoterapêutico que ambas referiram em suas narrativas.

Ao mesmo tempo em que narrativas de busca podem ser consideradas terapêuticas, estas também são limitadas (COUSER, 1997). O perigo inerente a estas histórias é que elas podem mostrar movimento progressivo através da doença e depreciar aqueles que não conseguem crescer com a experiência.

Ao tentarmos analisar a narrativa de Clarita segundo os tipos propostos por Frank (2012), concluímos que esta não se enquadra em nenhum dos três. Embora as mudanças apresentadas por ela possam parecer positivas a quem ouve ou lê a sua história, ela própria considera que mudou negativamente com a experiência da doença. É essa percepção que ela tem de si e de sua própria identidade que deve ser considerada, podendo estar relacionada à aceitação social do comportamento anterior e a não aceitação do comportamento atual. Caso Clarita considerasse as mudanças ocorridas em sua identidade como 
positivas, aí sim sua narrativa poderia ser considerada de restituição, visto que passou pelo diagnóstico, tratamento e deu continuidade a sua vida.

As narrativas de restituição, caos e busca, oferecem aos pesquisadores um meio de explorar as ligações entre cultura, os indivíduos e suas experiências de adoecimento, tais como o câncer de mama.

Couser (1997) argumenta que as narrativas de câncer de mama publicadas constituem o seu próprio e distinto subgênero de narrativas de doenças, pela ênfase na doença como força transformadora. Aqueles que sobrevivem ao câncer de mama mostram que o significado da doença vai muito além da conclusão do tratamento.

Simonton (1994) após longos anos de trabalho com pacientes oncológicos, afirma que o câncer deve ser entendido como uma mensagem de alerta para que as pessoas parem de fazer coisas que as machuquem e as angustiam e comecem a fazer coisas que lhe dêem prazer, coisas essas que exprimam coerência com as suas vontades. Ele ressalta o "outro lado" da doença, aquele que o indivíduo desperta para possibilidades antes tidas como inusitadas, de crescer interiormente, emocionalmente. Assim, na medida em que a vivência de um processo patológico interfere no dia-a-dia do indivíduo, uma nova percepção de vida pode surgir. A maneira como cada um percebe a vida é influenciada por valores condicionantes impostos pela sociedade (SIMONTON; SIMONTON; CREIGHTON, 1987).

De acordo com Kaiser (2008) as mulheres com câncer de mama enfrentam um conflito entre as definições culturais de sobrevivência e suas próprias batalhas em curso com o câncer. Ela percebeu que as respostas com relação à sobrevivência variavam mesmo entre uma amostra relativamente 
homogênea capturada em momentos semelhantes pós-tratamento. A autora identifica que há uma diversidade na forma em aceitar, rejeitar, ou mesmo modificar significados culturais relacionados à sobrevivência.

No plano social, construções contemporâneas do câncer de mama levam à simpatia e respeito pela doença, podendo ainda facilitar a obtenção de financiamento para pesquisa e tratamento (KAISER, 2008). A narrativa de sobrevivência vai ao encontro do modelo médico da doença no qual ela é diagnosticada, tratada e curada (FRANK, 1995). Entretanto esse tipo de narrativa desconsidera os efeitos duradouros do câncer de mama e a diversidade de respostas à doença. No plano individual, as mulheres têm a oportunidade de participar na cultura dominante através do consumo de materiais simbólicos como fitas cor de rosa, peças de vestuário, com poucas oportunidades de agir de maneiras alternativas. Adotar uma nova construção de sobrevivência implica em reconhecer os efeitos duradouros do câncer de mama e a diversidade de respostas à doença, significa ainda reconhecer os limites da medicina no controle do câncer. Compreendendo e aceitando os limites da medicina, algumas pessoas seriam menos dependentes de exames e intervenções médicas, o que também acarretaria a diminuição do poder das instituições. As mulheres que sobrevivem ao câncer de mama têm o direito de traçar o próprio futuro, dentro das reais limitações impostas pela doença (KAISER, 2008).

À medida que as mulheres se veem frente ao diagnóstico, se confrontam com alterações nas suas vidas que transformam definitivamente sua identidade social de pessoa saudável, para uma identidade de doente e incapacitada para suas atividades e, em alguns casos, dependente de seu familiar cuidador. 
Porém, esses não são os únicos traços com que essas pessoas se confrontam, no percurso de sua vida com o câncer. Elas se deparam com uma nova identidade que vai se formando durante essa trajetória: a identidade de sobrevivente (MUNIZ; ZAGO; SCHWARTZ, 2009).

Na construção de uma definição de sobrevivência, a cultura do câncer de mama deixou muitas mulheres em busca de representações que reconhecessem seus medos e a presença contínua do câncer em suas vidas (KAISER, 2008). 
Considerações finais

Os olhares sobre o câncer de mama têm mudado dramaticamente nas últimas décadas. Mulheres com câncer de mama hoje enfrentam menos vergonha, têm acesso a mais informações sobre sua doença e recebem apoio de outras pessoas. Essa é uma mudança extremamente positiva para pacientes com câncer de mama. No entanto, considerando-se a sobrevivência, a cultura relacionada ao câncer de mama tem deixado muitas mulheres em busca de representações que reconheçam os seus medos, a presença contínua do câncer em suas vidas e a forma de apresentar-se após a experiência do adoecimento.

Este estudo buscou, por meio de histórias de mulheres que experienciaram o câncer de mama, captar os sentidos atribuídos por elas a essa experiência e integrá-los em significados socialmente construídos, por meio da análise de narrativas.

As narrativas formuladas pelas participantes fornecem elementos para que elas se constituam reflexivamente (contando a sua história enquanto uma pessoa que passou pelo tratamento do câncer e pode ser considerada uma sobrevivente) e deem sentido as suas experiências. O pesquisador ao adotar essa perspectiva convidou seu sujeito de pesquisa ao diálogo e a entrar no processo reflexivo consciente. Dentro da organização das narrativas - o ponto a que se quer chegar; o encadeamento cronológico dos eventos, o relato das transformações as participantes produziram sentido para seu adoecimento e para si mesmas. 
Durante o processo de adoecimento e tratamento, as mulheres foram construindo significados a fim de se adaptarem à nova condição e, com isso, surge uma nova identidade, a de sobrevivente ao câncer. Com essa nova identidade, marcada pela experiência do adoecimento, as mulheres tentam retomar suas vidas e, planejam um futuro com esperança, apesar de uma sombra de incerteza quanto a estarem curadas.

A construção das narrativas deu-se inicialmente pelo diagnóstico, cheio de tormentos, seguido pelo tratamento e por fim a aquisição de uma nova vida, ou um estado aparente de estabilidade, que pode ou não assemelhar-se ao que era percebido anteriormente ao adoecimento.

$\mathrm{Na}$ maioria das narrativas observaram-se relatos de transformação e alcance de certa resolução, remetendo a um estado de melhora em relação ao que apresentaram durante o tratamento. Muitas mulheres se perceberam com uma nova identidade após a experiência do adoecimento, enquanto outras, apesar de se encontrarem longe do tratamento há um período mínimo de cinco anos, não se veem ainda como sobreviventes por estarem vivenciando a possibilidade de recorrência da doença. Muitas lembranças se mostraram presentes nas narrativas destas mulheres, referentes aos procedimentos terapêuticos vivenciados, às mudanças ocorridas em sua rotina, em sua aparência e nas relações afetivas e sociais.

Com as histórias relatadas pelas participantes, por meio de uma análise narrativa, foi possível compreender que os significados da experiência do adoecimento e sobrevivência ao câncer de mama são construídos ao longo de todo o processo. Por meio das narrativas, pode-se perceber que estas 
mulheres elaboram os significados da experiência do adoecimento conforme sua identidade individual. A despeito do número limitado de mulheres sobreviventes ao câncer de mama entrevistadas, os achados deste estudo evidenciam que a percepção das mesmas sobre 0 processo de adoecimento/sobrevivência mostra similaridades em algumas dimensões e diferenças em outras. É preciso considerar as diversidades vividas por cada mulher que experiencia o câncer de mama assim como as diferentes formas de significar a sobrevivência.

As narrativas produzidas pelas participantes do estudo se encaixam na estrutura de histórias, sendo o início das narrativas dado pela descoberta do diagnóstico, seguido pelo tratamento e a busca pelo retorno à condição de saúde.

A análise das narrativas adotada no estudo permitiu um aprofundamento nos aspectos relacionados à experiência do adoecimento, assim como as implicações desta experiência apresentadas pelas participantes.

A compreensão da experiência do câncer é sempre uma tarefa desafiadora. Considerando o referencial teórico utilizado, verificou-se que a maior parte das entrevistas pode ser caracterizada como de restituição ou reconstrução, em que as mulheres participantes encontram-se reconstruindo a vida após o câncer.

A oportunidade de elaborar a narrativa pode auxiliar a mulher a fazer uma reorganização de sua vida e pode oferecer sinalizações aos profissionais da ajuda que ela precisa receber. 
Algumas limitações precisam ser pensadas levando-se em consideração a figura do pesquisador. Tendo em vista que a pessoa conta sua experiência e organiza a sua narrativa considerando quem a está ouvindo, tentando guiar-se pela impressão que o outro terá a seu respeito, e geralmente projetando uma imagem favorável de si.

A população feminina com câncer de mama é um grupo crescente e, à medida que sua incidência, bem como o período de sobrevida aumentam, mais profissionais necessitam conhecê-la para melhor atendê-la. Assim, os achados deste estudo têm implicações importantes para o atendimento oferecido pelos serviços de saúde.

O fato destas mulheres passarem pela fatalidade de ter câncer e submeterem-se ao tratamento possibilita compreender o quanto sentem os limites existenciais, vivenciam a doença e o tratamento em suas vidas, inserindo-se num processo de incertezas que persiste para o resto da vida, embora elaborem o sentido de retomar sua vida de novo.

Com este estudo pode-se chegar a uma compreensão do sentido da experiência do câncer de mama na vida de algumas mulheres, podendo se estender a outras mulheres que partilham dessa experiência, contribuindo para o aperfeiçoamento do trabalho de profissionais da área da saúde que lidam com esta população.

Constatamos que os significados construídos evidenciam a necessidade de ampliar o foco de atenção dos profissionais de saúde, incluindo as referências socioculturais do contexto das pessoas que experienciam 0 adoecer e sobreviver ao câncer, ultrapassando a dimensão biológica do cuidar. 
Recomenda-se que outros estudos sejam realizados com vistas a investigar outros aspectos aqui não identificados e que possam facilitar a compreensão a respeito das mulheres sobreviventes ao câncer de mama. 


\section{REFERÊNCIAS ${ }^{1}$}

ALMEIDA, A. M.; MAMEDE, M. V.; PANOBIANCO, M. S.; PRADO, M. A. S.; CLAPIS, M. J. Construindo o significado da recorrência da doença: a experiência de mulheres com câncer de mama. Revista Latino-Americana de Enfermagem, Ribeirão Preto, v. 9, n. 5, p. 63-69, 2001.

ANDERS, J. C.; SOUZA, A. I. J. Crianças e adolescentes sobreviventes ao câncer: desafios e possibilidades. Ciência, Cuidado e Saúde, Maringá, v.8, n.1, p. 131-137, 2009.

ARAUJO, I. M. A; FERNADES, A. F. C. O significado do diagnóstico do câncer de mama para a mulher. Escola Anna Nery Rev. Enfermagem, Rio de Janeiro, v. 12, n. 4, p. 664-671, 2008.

ASHING, K.; PADILLA, G.; TEJERO, J.; KAGAWA-SINGER, M. Understanding the breast câncer experience of Asian American Women. Psycho-Oncology, Chichester, v.12, n.1, p. 38-58, 2003.

BARBOSA, A. M. Câncer: direito e cidadania. São Paulo: Arx, 2003.

BARBOSA, L. N. F.; FRANCISCO, A. L.; EKFEN, K. H. Adoecimento: o serpara-a-morte e o sentido da vida. Pesquisas e práticas psicossociais, São João Del Rei, v. 2, n. 1, p.54-60, 2007.

BERGAMASCO, R.; ANGELO, M. O sofrimento de descobrir-se com câncer de mama: como o diagnóstico é experienciado pela mulher. Revista Brasileira de Cancerologia, Rio de Janeiro, v. 47, n. 3, p. 227-282, 2001.

BIFFI, R. G.; MAMEDE, M. V. Suporte social na reabilitação da mulher mastectomizada: o papel do parceiro sexual. Revista da Escola de Enfermagem da USP, São Paulo, v. 38, n. 3, p. 262-269, 2004.

BLOOM, J. Surviving and thriving? Psycho-Oncology, Chichester, v.11, p.8992. 2002.

\footnotetext{
${ }^{1}$ De acordo com a Associação Brasileira de Normas Técnicas. NBR 6023.
} 
BOTTOMLEY, S. J.; KASSNER, E. Latte effects of childhood cancer terapy. Journal of Pediatric Nursing, Philadelphia, v. 18, n. 2, p. 126-133, 2003.

BOWIE, J.; CURBOW, B.; LAVEIST, T.; FITZGERALD, S.; PARGAMENT, K.The relationship between religious coping style and anxiety over breast cancer in African American women. Journal of Religion and Health, New York, v. 40, n. 4, p. 411-422, 2001.

BRASIL. Ministério da Saúde. Instituto Nacional de Câncer (INCA). Incidência de câncer no Brasil: estimativa 2010. 2010. Disponível em: $<$ http://www.inca.gov.br/estimativa/2010/index.asp?link=conteudo_view.asp\&ID =7>. Acesso em: 18 out. 2011 .

BRODY, H. Stories of sickness. New Haven: Yale University Press, 1987.

BROYARD, A. Intoxicated by my illness, and other writings on life and death. New York: Clarkson, Patter, 1992.

BRUNER, J. Actual minds, possible worlds. Cambridge: Harvard University Press, 1986.

BRUNER, J. Autobiografia de si-mesmo. In: Atos de significação. Tradução Sandra Costa. Porto Alegre: Artes Médicas, 1997. p. 88-121.

BURY, M. Chronic illness: a biographical disruption. Sociology of Healthy and IIIness, Henley on Thames, v. 4, n. 2, p. 167-182, 1982.

CARR, D. Time, narrative and history. Bloomington: Indiana University Press, 1986.

CARVALHO, M. M. M. J. Introdução à psiconcologia. São Paulo: Livro Pleno. 2002.

CHOUMANOVA, I.; WANAT, S.; BARRETT, R.; KOOPMAN, C. Religion and spirituality in coping in breast cancer: perspectives of Chilean women. The Breast Journal, Malden, v. 12, n. 4, p. 349-352, 2006. 
CLAYTON, M. F.; MISHEL, M. H.; BELYEA, M. Testing a model of symptoms, communication, uncertainty, and well-being, in older breast cancer survivors. Research in Nursing \& Health, New York, v. 29, n. 1, p. 18-39, 2006.

COUSER, G. T. Recovering bodies: illness, disability and life writing. Madison: University of Wisconsin Press, 1997.

CROSSLEY, M. Narrative psychology, trauma and study of self/ldentity. Theory \& Psychology, Gateshead, v.10, n. 4, p. 527-546, 2000.

DANN, N. J.; MERTENS, W. C. Talking a leap of faith: acceptance and value of a cancer program-sponsored spiritual event. Cancer Nursing, Washington, DC, v. 27, n. 2, p. 134-141, 2004.

DAVIES, M. L. Shattered assumptions: time and the experience of long-term HIV positivity. Social Science and Medicine, Oxford, v. 44, n. 5, p. 561-571, 1997.

DUARTE, R. Pesquisa qualitativa: reflexões sobre o trabalho de campo. Cadernos de Pesquisa. Rio de Janeiro, n. 115, p. 139-154, 2002.

DUARTE, T. P.; ANDRADE, A. N. Enfrentando a mastectomia: análise dos relatos de mulheres mastectomizadas sobre questões ligadas a sexualidade. Estudos de Psicologia, Natal, v. 8, n. 1, p.155-163, 2003.

ENGEL, J.; KERR, J.; SCHLESINGER-RABB, A.; SAUER, H.; HOLZEL, D. Quality of life following breast-conserving therapy or mastectomy: results of a 5year prospective study. Breast Journal, Cambridge, v. 10, n. 3, p. 223-231, 2004.

FEUERSTEIN, M. Defining cancer survivorship. Journal of Cancer Survivorship, New York, v. 1, n. 5, p. 5-7, 2007.

FOBAIR, P.; O'HANLAN, K.; KOOPMAN, C.; CLASSEN, C.; DIMICELE, S.; DROOKER, N.; LOULAN, J.; WALLSTEN, D.; GOFFINET, D.; MORROW, G.; SPIEGEL, D. Comparison of lesbian and hetero-sexual women's response to newly diagnosed breast cancer. Psycho-Oncology, Chichester, v. 10, n. 1, p. 40-51, 2001. 
FRANK, A. The rhetoric of self-change: illness experiences as narrative. Sociological Quarterly, lowa, v. 34, n. 1, p. 39-52, 1993.

FRANK, A. The wounded storyteller: body, illness and ethics. Chicago: University of Chicago Press, 1995.

FRANK, A. Practicing dialogical narrative analysis. In: HOLSTEIN, J. A.; GUBRIUM, J. F. (Eds.) Varieties of narrative analysis. New York: Sage, 2012. p. 33-52.

FRANKL, V. Em busca de sentido: um psicólogo no campo de concentração. Petrópolis: Vozes, 1991.

FRID, I.; ÖHLÉN, J.; BERGBOM, I. On the use of narratives in nursing research. Journal of Advanced Nursing, Oxford, v. 32, n. 3, p. 696-703, 2000.

FROST, M.; SUMAN, V.; RUMMANS, T.; DOSE, A. M.; TAYLOR, M., NOVOTNY, P.; JOHNSON, R.; EVANS, R. E. Physical, psychological and social well-being of women with breast cancer: the influence of disease phase. Psycho-Oncology, Chichester, v. 9, n. 3, p. 221-31, 2000.

GALL, T. L.; CORNBLAT, M. W. Breast cancer survivors give voice: a qualitative analysis of spiritual factors in long-term adjustment. PsycoOncology, Chichester, v. 11, n. 6, p. 524-535, 2002.

GANZ, P.A.; LORNA, K.; STANTON, A.; KRUPNIK, J.L.; ROWLAND, J.H.; MEYEROWITZ, B.E.; BOWER, J.E.; BELIN, T.R. Quality of life at the end of primary treatment of breast cancer: first results from the moving beyond cancer randomized trial. Journal of the National Cancer Institute, v.96, n.5, p.376387, 2004. Disponível em: http://jnci.oxfordjournals.org/content/96/5/376.full.pdf+html>. Acesso em: 03 nov.2011.

GARRO, L. C. Narrative representations of chronic illness experience: cultural models of illness, mind, and body in stories concerning the temporomandibular joint (TMJ). Social Science and Medicine, Oxford, v. 38, n. 6, p. 775788, 1994.

GERGEN, K.J. Self-Narration in Social Life. In: Realities and relationships: soundings in social construction. Cambridge: Harvard University Press, 1997. p. 185-209. 
GERMANO, I.; CASTRO, C.A. Pesquisa em Saúde: Perspectivas narrativistas, métodos e níveis de análise. Psicologia Argumento, Curitiba, v. 28, n. 60, p.17-29, 2010.

GIANINI, M. M. S. Câncer e gênero: enfrentamento da doença. 2007. Disponível em: <http://www.psicologia.pt/artigos/textos/A0369.pdf>. Acesso em: 16 out. 2011.

GIMENES, M. G. G. (Org.) A mulher e o câncer. São Paulo: Editorial Psy, 1997.

GIMENES, M. G. G.; QUEIRÓZ, E. As diferentes fases de enfrentamento durante o primeiro ano após a mastectomia. In: GIMENES, M. G. G.; FÁVERO, M. H. (Org.). A mulher e o câncer. Campinas: Livro Pleno, 2000. p. 173-195.

GOMES, R.; SKABA, M. M. V. F.; VIEIRA, R. J. S. Reinventando a vida: proposta para uma abordagem sócio-antropológica do câncer de mama feminina. Caderno de Saúde Pública, Rio de Janeiro, v. 19, n. 1, p. 197-204, 2002.

GOOD, B. J. Medicine, rationality, and experience: an anthropological perspective. Cambridge: Morgan, 1995.

HOFFMANN, F. S.; MULLER, M. C.; FRASSON, A. L. Repercussões psicossociais, apoio social e bem-estar espiritual em mulheres com câncer de mama. Psicologia, Saúde e Doenças, Lisboa, v. 7, n. 2, p. 239-254. 2006.

HOLZNER, B.; KEMMLER, G.; KOPP, M.; MOSCHEN, R. Quality of life in breast cancer patients-not enough attention for longterm survivors? Psychosomatics, Irvington, v. 42, n. 2, p. 117-123, 2001.

HOWLAND, J. H. What are câncer survivors telling us? Cancer Journal, Sudbury, v. 14, n. 6, p. 361-368, 2008.

JANOFF-BULMAN, R. Shattered assumptions: towards a new psychology of trauma. New York: Free Press, 1992. 
JEMAL, A., SIEGEL, R., WARD, E., HAO, Y. , XU, J., MURRAY, T., THUN, M. J. Cancer statistics 2008. Cancer Journal for Clinicians, Hoboken, v. 58, n. 2, p. 71-96, 2009.

JOHNSON, N. S.; MANDLER, J. .M. A tale of two structures: underlying and surface forms in stories. Poetics, v. 9, p.51-86, 1980.

JOVCHELOVITCH, S., BAUER, M. W. Entrevista Narrativa. In: BAUER, M. W.; GASKELL, G. (Eds.). Pesquisa qualitativa com texto, imagem e som: um manual prático. Tradução Pedrinho Guareschi. Petrópolis: Vozes, 2008. p. 90113.

KAISER, K. The meaning of the survivor identity for women with breast câncer. Social Science and Medicine, Oxford, v. 67, n. 1, p. 78-87, 2008.

KLEINMAN, A. The illness narratives: suffering, healing and the human condition. New York: Basic Books, 1988.

KORNBLITH, A. B.; HERNDON, J. E.; ZUCKERMAN, E.; VISCOLI, C. M. HORWITZ, R. I.; COOPER, M. R.; HARRIS, L.; TRACZUK, K. H.; PERRY,M. C.; BUDMAN, D.; NORTON, L.; HOLLAND, J. C. Social support as a buffer to the psychological impact of stressful life events in women with breast cancer. Cancer, New York, v. 91, n. 2, p. 443-454, 2001.

KÓVACS, M. J.; AMORIM, A. C. C.; FILHO \& SGORLON, L. C. A. Avaliação da qualidade de vida em pacientes oncológicos em estado avançado da doença. In: CARVALHO, M. M. M. J. (Org.), Psico-oncologia no Brasil: resgatando o viver. São Paulo: Summus, 1998, p.159-185.

LANGEVELD, N. E.; STAM, H.; GROOTENHUIS, M. A.; LAST, B. F. Quality of life young adults survivors of childhood cancer. Supportive Care Cancer, Berlin, v. 10, n. 8, p. 579-600, 2002.

LANZA, L.F. Ser-criança-com-câncer em etapa final de tratamento - sua visão de futuro. 2008. 89 f. Dissertação (Mestrado) - Escola de Enfermagem de Ribeirão Preto, Universidade de São Paulo, Ribeirão Preto, 2008.

LIBERATO, R. P.; MACIEIRA, R. C. Espiritualidade no enfrentamento do câncer. In: CARVALHO, V.; FRANCO, M. H. P.; KOVÁCS, M. J.; LIBERATO, R. P.; MACIEIRA, R. C.; VEIT, M. T.; GOMES, M. J. B.; BARROS, L. H. C. (Orgs.), Temas em psico-oncologia. São Paulo: Summus, 2008. p. 414-431. 
LITTLE, M.; PAUL, K.; JORDENS, C.F.; SAYERS, E.J. Survivorship and discourses of identity. Psyco-Oncology, Chichester, v.11, n.2, p. 170-178, 2002.

MACINTYRE, A. After virtue. New York: Notre Dame University Press, 1981.

MAKLUF, A. S. D.; DIAS, R. C.; BARRA, A. A. Avaliação da qualidade de vida em mulheres com câncer de mama. Revista Brasileira de Cancerologia, Rio de Janeiro, v.52, n.1, p. 49-58, 2006.

MANNING-WALSH, J. Spiritual struggle: effect on quality of life and life satisfaction in women with breast cancer. Journal of Holistic Nursing, Springfield, v. 23, n. 2, p.120-140, 2005.

MARQUES, L. F. A saúde e o bem-estar spiritual em adultos Porto-Alegrenses. Psicologia, Ciência e Profissão, Brasília, DF, v .23, n. 2, p. 56-65, 2003.

MASTELLARO, M. J.; MENDONÇA, R. M. H.; PERINA E.; CAPPELLARO, K. M. C.; BRANDALISE, S. R. Clínica de atendimento após o término da terapia (CATT): compromisso com o futuro. Âmbito Hospitalar, São Paulo, n. 169, p. 30-32, 2004.

MATHIESON, C.; STAM, H. Renegotiating identity: cancer narratives. Sociology of Health and IIIness, Henley on Thames, v. 17, n. 3, p. 283-306, 1995.

MENEZES, C. N. B.; PASSARELI, P. M.; DRUDE, F. S.; SANTOS, M. A.; VALLE, E. R. M. Câncer infantil: organização familiar e doença. Revista Mal Estar e Subjetividade, Fortaleza, v. 7, n. 1, 2007. Disponível em:< http://pepsic.bvsalud.org/scielo.php?pid=S1518-

61482007000100011\&script=sci_arttext>. Acesso: 03 nov. 2011.

MERAVIGLIA, M. Effects of spitituality in breast cancer survivors. Oncology Nursing Forum, v. 33, n. 1, p. E1-E7, 2006. Disponível em:< http://ons.metapress.com/content/45726u6551g05213/fulltext.pdf>. Acesso: 03 nov. 2011.

MINAYO, M. C. S. O desafio do conhecimento: pesquisa qualitativa em saúde. 10. ed. São Paulo: Hucitec, 2007. 
MISHLER, E. The analysis of interview narratives. In: SARBIN, T. Narrative psychology: the storied nature of human conduct. Wetsport: Praeger, 1986. p.233-255.

MULLAN, F. Preface: the culture of survivorship. Seminars in Oncology Nursing, Orlando, v. 17, n. 4, p. 234-235, 2001.

MUNIZ, R. M.; ZAGO, M. M. F.; SCHWARTZ, E. As teias da sobrevivência oncológico: com a vida de novo. Texto e Contexto em Enfermagem. Florianópolis, v. 18, n. 1, p. 25-32, 2009.

MURRAY, M. Levels of narrative analysis in health psychology. Journal of Health Psychology, New York, v. 5, n. 3, p. 337-347, 2000.

ORTIZ, M. C. A.; LIMA, R. A. G. Experiência de familiares de crianças e adolescentes, após o término do tratamento contra o câncer: subsídios para o cuidado de enfermagem. Revista Latino-Americana de Enfermagem, Ribeirão Preto, v. 15, n. 3, p. 411-17, 2007.

PARK, C. L.; ZLATEVA, I.; BLANK, T. O. Self-identity after câncer: "survivor", "victim", "patient", and "person with câncer". Journal of General Internal Medicine, Secaucus, v. 24, n. 2, p. 430-435, 2009.

PARKER, P.; BAILE, W.; MOOR, C.; COHEN, L. Psychosocial and demographic predictors os quality of life in a large sample of cancer patients. Psycho-Oncology, Chichester, v. 12, n. 2, p. 183-193, 2003.

PENNA, T. L. M. Dinâmica Psicossocial de famílias de pacientes com câncer. In: MELLO FILHO, J.; BURD, M. (Orgs.). Doença e família. São Paulo: Casa do Psicólogo. 2004. p. 379-389.

POLIT, D. F.; HUNGLER, B. P. Fundamentos de pesquisa em enfermagem. 3. ed. Porto Alegre: Artes Médicas, 1995.

POLLIN, I. Medical crisis counseling: short-term terapy for long-term illness. New York: W.W.Norton, 1995.

POWE, B. D., FINNIE, R. Cancer fatalism. Cancer Nursing, New York, v. 26, n. 6, p. 454-467, 2003. 
RABELO, M. C. A construção narrativa da doença. In: REUNIÃO DA ANPOCS, 18, Salvador, 1994. Salvador: Grupo de Trabalho Saúde, Corpo e Pessoa, 1994.

REUBEN, S. H. Living beyond câncer: finding a new balance. President's Cancer Panel 2003-2004: annual report. Bethesda: National Cancer Institute, 2004.

RIESSMAN, C. K. Strategic uses of narrative in the apresentation of self and illness: a research note. Social and Science Medicine, Oxford, v. 30, n. 11, p. 1195-1200, 1990.

RONSON, A.; BODY, J. Psychosocial rehabilitation of cancer patients after curative therapy. Support Care Cancer, New York, v. 10, n. 4, p. 281-291, 2002.

ROSSI, L.; SANTOS, M. A. Repercussões psicológicas do adoecimento e tratamento em mulheres acometidas pelo câncer de mama. Psicologia Ciência e Profissão, Brasília, DF, v. 23, n. 4, p. 32-41. 2003.

RZEZNIK, C.; DALL'AGNOL, C. M. (Re) descobrindo a vida apesar do câncer. Revista Gaúcha de Enfermagem, Porto Alegre, v. 21, p. 84-100. 2000. Número especial.

SALES, C.; PAIVA, L.; SCANDIUZZI, D.; ANJOS, A. C. Qualidade de vida de mulheres tratadas de câncer de mama: funcionamento social. Revista Brasileira de Cancerologia, v.47, n.3, p.263-272, 2001. Disponível em:< http://www.inca.gov.br/rbc/n_47/v03/pdf/artigo2.pdf>. Acesso: 03 nov. 2011.

SANT'ANNA, D. B. A mulher e câncer na história. In: M. G. G. GIMENES \& M. H. FÁVERO. A mulher e o câncer. Campinas: Livro Pleno, 2000. p. 43-70.

SARBIN, T. R. Narrative psychology: The storied nature of human conduct. New York: Praeger, 1986.

SILVA, D. G. V.; TRENTINI, M. Narrativas como técnica de pesquisa em enfermagem. Revista Latino-Americana de Enfermagem, Ribeirão Preto, v.10, n.3, p.423-432, $2002 . \quad$ Disponível em: <http://www.scielo.br/pdf/rlae/v10n3/13352.pdf>. Acesso em: 27 out. 2010. 
SILVA, L. C. Câncer de mama e sofrimento psicológico: aspectos relacionados ao feminino. Psicologia em Estudo, Maringá, v. 13, n. 12, p. 239-237, 2008.

SILVA, S. S.; AQUINO, T. A. V.; SANTOS, R. M. O paciente com câncer: cognições e emoções a partir do diagnóstico. Revista Brasileira de Terapias Cognitivas, $\quad$ v.4, n.8, 2008. Disponível em: <http://espiritualidadesentido.yolasite.com/resources/O\%20Paciente\%20com\% 20cancer.pdf>. Acesso em: 3 out. 2011.

SILVA, V. C. E. O impacto da revelação do diagnóstico de câncer na percepção do paciente. 2005. 218 f. Dissertação (Mestrado) - Escola de Enfermagem de Ribeirão Preto, Universidade de São Paulo, Ribeirão Preto, 2005. SIMONTON, O. C. Cartas de um sobrevivente: o caminho da cura através da transformação interior. São Paulo: Summus, 1994.

SIMONTON, O. C; SIMONTON, S. M.; CREIGHTON, J. L. Com a vida de novo: uma abordagem de auto-ajuda para pacientes com câncer. São Paulo: Summus, 1987.

STEVENS, P. E.; HALL, J. M.; MELEIS, A. I. Narratives as a basis for culturally relevant holistic care: ethnicity and everyday experiences of women clerical workers. Holistic Nursing Practice, Maryland, v. 6, n. 3, p. 49-58, 1992. TAYLOR, C. Sources of self: the making of modern identity. Cambridge: Cambridge University Press, 1989.

TAYLOR, E. J. Spiritual quality of life. In: KING, C. R.; HINDS, P. S. (Eds.) Quality of life: from nursing and patient perspectives. 2nd ed. Boston: Jones and Bartlett, 2003. p. 93-116.

THOMAS-MACLEAN, R. Understanding breast câncer stories via Frank's narrative types. Social Science and Medicine, Oxford, v. 58, p. 1647-1657, 2004.

THULER, L. C. S.; MENDONÇA, G. A. Estadiamento inicial dos casos de câncer de mama e colo do útero em mulheres brasileiras. Revista de Ginecologia e Obstetrícia, Rio de Janeiro, v.27, n.11, p.656-660, 2005.

TURATO, E. R. Métodos qualitativos e quantitativos na área da saúde: definições, diferenças e seus objetos de pesquisa. Revista de Saúde Pública, São Paulo, v. 39, n. 3, p. 507-514, 2005. Disponível em:< http://www.scielo.br/pdf/rsp/v39n3/24808.pdf>. Acesso: 03 nov. 2011.

TWOMBLY, R. What's in a name: who is a câncer survivor? Journal of the National Cancer Institute, Oxford, v. 96, n.19, p. 1414-1415, 2004. 
VANCHON, M. L. S. The meaning of illness to a long term survivor. Seminars in Oncology Nursing, Orlando, v. 17, n. 4, p. 279-283, 2001.

VEIT, M. T.; BARROS, M. C. M.; CHWARTZMANN, F. Serviços de psicooncologia em hospitais. In: CARVALHO, M. M. M. J. (Org.). Psico-oncologia no Brasil: resgatando o viver. São Paulo: Summus, 1998.

VENÂNCIO, M. R. A morte em seu mostrar-se ao paciente oncológico em situação de metástase. 2005. 195 f. Dissertação (Mestrado) - Escola de Enfermagem de Ribeirão Preto, Universidade de São Paulo, Ribeirão Preto, 2005.

VIEIRA, C. P.; LOPES, M. H. B. M.; SHIMO, A. K. K. Sentimentos e experiências na vida das mulheres com câncer. Revista Escola de Enfermagem da Usp, São Paulo, v. 41, n. 2, p. 311-316, 2007.

VIGO, M.; CARN, M. R. Apoyo social en adultos puertorriqueños com diagnóstico de cáncer. Puerto Rico Health Sciences Journal, San Juan, v. 21, n. 1, p. 51-56. 2002.

WALSH, J. M. Social support as a mediator between sympton distress and quality of life in women with breast cancer. Journal of Obstetric Gynecologic and Neonatal Nursing, Philadelphia, v. 34, n. 4, p. 482-493. 2005.

WORLD HEALTH ORGANIZATION (WHO). Cancer. Geneva, 2010. Disponível em: <http://www.who.int/topics/cancer/en/>. Acesso em: 26 out. 2010.

YARDLEY, L. (Ed.) Material discourses of healthy and illness. London: Routledge, 1997. 


\section{APÊNDICE A - TERMO DE CONSENTIMENTO LIVRE E ESCLARECIDO}

Meu nome é Lara de Faria Lanza, sou pesquisadora da Escola de Enfermagem de Ribeirão Preto, da Universidade de São Paulo, e estou desenvolvendo um estudo que visa compreender a história de pessoas que passaram pelo tratamento do câncer.

Gostaria de convidá-lo a participar deste estudo por meio de uma conversa informal (entrevista), que acontecerá em dois momentos, podendo ser no local de atendimento médico, em seu domicílio, ou outro de sua preferência, caso aceite participar.

Este trabalho é importante, pois visa ajudar os profissionais de saúde a atenderem melhor às necessidades de pessoas que passaram pelo câncer, assim como você. Dessa forma, sua colaboração é muito valiosa.

Para participar deste estudo, você deve estar ciente que:

a) Você é livre para recusar participar ou retirar seu consentimento, em qualquer fase da pesquisa, sem penalização alguma e sem prejuízo ao seu cuidado;

b) Seu nome ou qualquer informação que dê indícios para identificá-lo serão omitidos;

c) Caso surja alguma dúvida sobre a pesquisa, você poderá esclarecêla a qualquer momento com a pesquisadora;

d) Todas as informações serão mantidas em sigilo, sendo que serão utilizadas somente para este estudo e apenas serão publicadas e/ou apresentadas com objetivo científico;

e) Caso aceite participar da pesquisa, você será entrevistado e esta entrevista será gravada pela pesquisadora, para posterior análise.

f) Haverá ressarcimento das despesas decorrentes da participação na pesquisa;

g) Não há riscos significativos em participar deste estudo.

h) Após a entrevista, você será encaminhado adequadamente para atendimento, caso seja necessário.

Eu, aceito participar deste estudo, sendo que minha participação é voluntária e estou livre para, em qualquer momento, desistir da participação, sem qualquer prejuízo. Eu recebi uma cópia deste termo e a possibilidade de poder lê-lo.

Assinatura do participante:

Data:

Lara de Faria Lanza - Responsável pela pesquisa

Caso tenha alguma dúvida e queira mais esclarecimentos, pode ligar para (16) 8106- 5000 e falar com Lara de Faria Lanza, responsável pela pesquisa. 
APÊNDICE B - Entrevista na íntegra

\section{Identificação}

Clarita tem 59 anos (na data em que foi realizada a entrevista), trabalha como encarregada de sessão em uma usina de açúcar no interior de MG, é divorciada e mãe de uma filha de 38 anos. Recebeu o diagnóstico de câncer de mama em 2005, passou por cirurgia, radioterapia e hormonioterapia.

\section{Entrevista (duração: 38 min.)}

$$
\begin{aligned}
& \text { E - Pesquisadora } \\
& \text { C - Clarita (participante) }
\end{aligned}
$$

E- Eu gostaria que você me contasse a sua história enquanto uma pessoa que passou pelo tratamento do câncer e hoje pode ser considerada uma sobrevivente.

C- É, mas é difícil porque a gente muda muito, muda, mas muda mesmo, você mesmo sente que mudou, eu sinto que eu mudei muito. Eu era uma pessoa muito mais legal eu acho, depois que eu passei por esse problema do câncer, assim, eu achei que isso aí não poderia acontecer comigo, porque eu nunca desejei mal pra ninguém, eu nunca fiz mal pra ninguém, eu sempre fui uma pessoa muito boa. Então, eu achei que podia acontecer com qualquer pessoa, menos comigo, então eu não merecia isto que eu tava passando. Então meu diagnóstico lá Minas foi assim "é trinta dias" e minha filha é advogada, minha filha mora aqui, ela falou "não, vou levar minha mãe em vários médicos, vou tratar da minha mãe, não é assim não". Queria tirar todo o meu peito, eu levei tanto choque, tanto choque que eu fiquei sentindo mal, eu nunca senti tão mal igual quando o médico me passou que eu tava com câncer, ele falou na lata assim. Eu fui, eu tinha igual uma pintinha assim muito pequenininha, não tinha caroço no peito não, eu fui fazer exame de rotina, que eu fui fazer, então por causa da idade eu fazia mamografia, então eu fui fazer exame de rotina, sem problema nenhum, que eu faço um check-up todo ano, aí achei igual essa pintinha assim um nódulo. Aí eu fui numa Dra. M e ela falou "não, não é câncer 
não precisa" - deu um negócio de gordura, não deu câncer "não precisa tirar, tira-se quando tem caroço, quando tem tumor". Ai eu pus aquilo na cabeça, falei "nossa esse negócio pode virar câncer, eu quero tirar, eu quero tirar, eu quero tirar". Aí eu fui no outro médico, dr. R. falei "eu pago pra tirar, eu quero tirar, eu quero fazer biópsia". Por que eu ia pelo convênio da Unimed e a médica falou "não, só tira quando apalpa, quando tem caroço". Aí fui no meu médico particular e falei "eu não quero nem saber, eu quero tirar, eu vou pagar particular, eu quero tirar e fazer biópsia, porque eu nunca tive isso, por que vou ter agora". Aí ele pegou e falou assim "então, vai ter que agulhar, porque não sente assim, sabe, apalpando, então vai ter que agulhar". Eu falei "faz o que o sr. quiser, mas eu quero que tire e faz uma biópsia". Aí eu fui no raio $x$, eles agulharam, a agulha ficou no meu peito pra eu operar, é porque não sentia, então eu fiz o raio $x$ e agulha ficou fincada assim na hora que eu tava fazendo o raio $x$, aí fincou a agulha, foi o médico que fincou a agulha no lugar que tava. Aí quando ele tava me operando, operei sete horas da noite, ficou na maior alegria "olha aqui, olha aqui" porque tinha nos dois peito, ele falou "de cá não é câncer não, mas de cá, olha, tem um rabinho, é câncer, é câncer", falou desse jeito pra mim. Aí tirou, falou assim, eu tava vendo tudo porque anestesiou só assim, e fui pra casa no mesmo dia, no mesmo dia eu fui pra casa porque ele falou pra mim, eu internei particular, ele falou pra mim " não, vou te operar e você já pode ir pra casa, vou fazer um curativo, porque não é nada grave não, só tirar porque você quer que tira pra fazer biópsia, é só isso". Aí na hora que ele operou ele falou "nesse de cá..."- o direito - "...eu conheço o câncer, tem um rabinho, aqui é câncer, é câncer", mas aí eu peguei e falei "não é nada", porque não tinha caroço nem nada né, mas assim mesmo eu fiquei com aquilo na cabeça. Aí depois de uma semana ele foi me dar o resultado, aí no dia que eu fui pegar o resultado eu falei pra minha filha "ó, você vem cá em Minas que eu vou pegar o resultado". E na hora que ele tava me operando, ele ficou na maior alegria que falou que tinha descoberto o câncer, sabe, eu até chorei, minha lágrima correu porque, uai, ficar alegre com uma coisa tão ruim na gente? Mas assim, ele, de certo ele falou "ah salvei uma vida que no início...", a cabeça dele é diferente da gente né. Aí, mas eu falei pra minha filha "eu não gostei, porque ele ficou numa alegria danada, então você vai comigo". Aí eu fui receber o resultado com a minha filha, aí ele falou pra minha filha "o negócio é 
que tem que tirar o peito inteiro dela, é um carcinoma in situ, o carcinoma in situ não invade margem, mas ela não vai fazer nem radio, nem química, nem nada, porque dela tá muito no início, mas nós vamos tirar o peito dela todinho e vai ver se vai precisar esvaziar a axila". Aí a minha filha falou assim "não", aí ele falou "é, porque se não tirar é trinta dias, o câncer se expande". Aí minha filha falou assim "não, eu vou levar a minha mãe, eu moro em Ribeirão, eu vou levar minha mãe lá, e vou passar minha mãe por vários médicos e vou tirar opinião de vários médicos, aí depois que eu tirar opinião de vários médicos, aí no caso eu volto a falar com você, se todos falarem que minha mãe tem que tirar toda a mama...". Aí ele falou "porque aí nós esvaziamos e colocamos um silicone, um negócio por dentro que o peito fica igual, do mesmo jeito, aí não mexe nem no bico nem nada". E eu fiquei, eu nunca passei mal na minha vida igual eu passei, eu senti um mal estar tão grande, mas tão grande que eu olhei pra minha filha que tava assim e falei pra minha filha "eu to passando mal de verdade, e é muito mal". Aí ele chamou a enfermeira correndo, aí me deu um copo dágua, mas eu nunca senti na minha vida igual eu senti naquela hora, eu não sei se a minha pressão subiu ou baixou, se juntou as duas, eu sei que as minhas vista escureceu, eu senti um mal estar, mas um mal estar maior do mundo assim, uma coisa que eu nunca tinha sentido na vida, uma pressão no peito, uma coisa ruim, eu falei "agora eu morro, eu morro com esse negócio, com esse mal estar", me deram um copo dágua, minha filha "calma mãe, calma mãe". Aí a minha filha falou "nós não vamos nem passar em casa, daqui nós vamos direto pra Ribeirão". Aí a minha filha tinha posto o carro lá em frente à Santa Casa, que ele me atendeu no consultório da Santa Casa, aí minha filha falou assim "daqui nós já vamos pra casa, vamos pra Ribeirão, você não esquenta não, depois lá eu dou um jeito". Aí minha filha queria a lâmina comprovando que eu tinha câncer, aí minha filha falou assim "eu preciso da lâmina pra levar pra Ribeirão Preto, porque a minha mãe vai passar por vários médicos lá", aí falaram pra minha filha "ah, não pode dar a lâmina, porque a lâmina não pode sair do laboratório". Aí minha filha pegou mostrou a carteirinha da $O A B$, que ela é advogada, falou "se vocês não me entregarem eu vou fazer um boletim de ocorrência, eu vou procurar a justiça pra ter ou a gente vai pegar do mesmo jeito dentro da lei”. Aí chamaram o chefe do laboratório que já tava em casa, já era de noite, aí mandou entregar pra minha 
filha, aí entregou numa caixinha de isopor, mas era pra devolver de novo pra lá, aí minha filha falou "eu devolvo", assinou um termo de responsabilidade e minha filha devolveu. Aí vinha pro laboratório aqui em Ribeirão, viemos direto pro laboratório, ficamos aí fazendo os exames tudo, chegamos aqui era quase meia-noite, mesmo assim foi feito os exames tudo, aí minha filha ligou pro dr.V, aí diz que o dr.V era muito bom pra tratar de câncer tudo. Aí eu fui no dr.V pegou, olhou os exame tudo e falou "é um princípio de câncer sim, tem que tratar, agora eu vou operar sua mãe de novo". Eu falei "nossa, mas tem uma semana que eu tomei anestesia", porque naqueles exames, tinha que esperar o resultado dos exames, falei "tem uma semana que eu tomei anestesia". Aí o dr.V falou "não tem problema, temos que garantir a margem de segurança". Aí quando eu fui entrar na sala de cirurgia, aqui neste serviço, ele falou pra minha filha "você assina um termo de responsabilidade que só abrindo que a gente vai saber como que tá o peito da sua mãe, aí ou tira tudo e esvazia debaixo da axila, só depois que abrir que eu vou saber direito o que ta acontecendo com a sua mãe". Aí minha filha assinou chorando, aí eu também senti assim super mal, mas eu falei "seja o que Deus quiser, eu já to na pior mesmo né, tem que enfrentar". Aí falei pra minha filha "não esquenta não". Aí minha filha arrumou o quarto, ficou lá no quarto me esperando com a sogra dela, com o meu genro, aí eu operei e voltei. Quando eu voltei da cirurgia eu não sabia se tinha tirado todo o peito, se não tinha, tava cheio de curativo assim. Aí minha filha falou assim "ai mãe, o médico falou que não foi preciso tirar o peito nem mexer nas axilas, foi pouquinho, tirou só o quadrante assim, a sra. vai ficar bem". Aí eu peguei falei pra minha filha "antes isso né". Aí fiz o tratamento com o dr.V, aí foi dando tudo certo, foi dando tudo certo, mas o que eu passei eu não quero pra ninguém. Porque é uma doença que é a mesma coisa que fala pra você assim ó uma sentença de morte, uma sentença de morte com prazo curto, que se fosse uma sentença de morte com prazo longo ainda você ficava satisfeita, mas o médico vira pra você e fala pra você assim, ele te dá uma sentença de morte com um prazo bem curto que você não tá esperando aquilo, que você não quer aquilo pra você, você acha que você não precisa passar... E tem mais, eu acho que os médicos tinham que pensar bem porque o câncer não dá sintomas, ele não dá sintoma, ele vem silencioso, então pra pessoa que tá com câncer ela tá com a saúde imensa, eu achava que eu tava vendendo saúde né, 
ainda falava "graças a Deus que eu tenho saúde", isso não saía da minha boca toda hora, que eu não sentia nada, eu trabalhava, eu levava a minha vida tranqüila, eu fui fazer um exame de rotina. Então, você vai fazer um exame de rotina, na tua cabeça você está cheia de saúde e o médico vem e solta aquela bomba em cima de você, é a mesma coisa que falar "olha, você tem pouquinho tempo de vida, você vai morrer logo, você tá com câncer". Câncer já é uma sentença de morte, então eu acho assim, é muito despreparo, eu se eu tivesse no lugar deles eu trabalhava primeiro a pessoa, com a cabeça da pessoa, falava pra pessoa "olha, você não tá com a saúde que você pensa que tá, certo? Mas o seu caso é esse, o seu caso pode ter tratamento, pode não dar, pode morrer igual todo mundo vai morrer mesmo...", mas não é assim na batata a coisa, então eu acho assim que todas as pessoas que tem câncer assim sofre muito por o pessoal não saber lidar com isso, certo? Eu penso assim, eu tenho um colega de serviço que tá com câncer aqui na perna, ele falou a mesma coisa pra mim, que o médico falou pra ele assim "ó, se for no osso é muito ruim, se for no osso é um câncer raro, nós temos que tirar a tua perna e vai ser bem problemático, agora se for, nós não sabemos ainda, nós estamos estudando, não sabemos ainda se é no músculo, se é na carne, se for na carne é fácil". Mas eu acho assim que ele não devia falar no osso... é um câncer "é um câncer, nós vamos tratar, nós vamos cuidar" certo? Mas já falar pro cara de cara assim, o cara tem uma saúde de ferro, o cara nunca ficou doente na vida, o cara ter assim aquela coisa no ouvido que vai ficar sem uma perna, certo? Então, eu acho assim, eu não sei eu posso ta errada, porque às vezes tem que fazer é assim mesmo, certo? Às vezes é eu que to errada, mas eu falo assim que tinha que ter um jeitinho melhor pra conversar...

E. Tem formas e formas pra falar né, é a vida da pessoa...

C. Porque já tem outros médicos, igual um médico lá em Minas que chama dr.N. ele vai daqui de Ribeirão para Minas, nossa tudo quanto é paciente quer consultar com ele, só porque ele abraçou uma velhinha que a família tava toda assustada que a mulher tava com um câncer muito adiantado que não ia viver mais, abraçou a velhinha e falou pra velhinha assim "ninguém pega câncer, câncer não pega em ninguém" e falou pra velhinha assim " nós vamos tratar de você e câncer não pega, pode encostar a mão nela, pode pegar...". E essa velhinha até chorou de alegria que a família tava afastando tudo dela, o câncer 
dela tava muito adiantado, já tava cheirando ruim e tudo...Então é uma coisas assim que agora todo mundo quer ir só nele, certo? Porque ele soube passar um carinho especial, uma coisa, a mulher morreu, a mulher não sobreviveu, mas só aquilo que ele fez pra ela eu acho que valeu a vida inteira, certo? Agora todo mundo quer ir nele, todo mundo acha que ele é bom, porque ele é isso, porque ele é aquilo, porque ele ajuda, porque ele é assim ele... ele sente assim que a pessoa já ta na pior mesmo, então não precisa piorar o resto... A pessoa com câncer, eu acho que a pior doença que existe é o câncer, eu acho que não existe doença pior que o câncer, eu acho, porque o câncer é uma doença assim ele não dá sintoma, ele vem traiçoeiro, caladinho e depois quando a gente recebe a notícia é a pior notícia do mundo, o tratamento é um tratamento que judia muito, os remédio é muito difícil, certo, você sente mal mesmo né, então se falar que não sente é mentira... A química... eu fiz a radio, a radio queima, mais queima muito...

\section{E. Você fez quantas sessões?}

C.28 radio, minha filha punha um chá de camomila na geladeira e pegava uma fralda e punha, a fralda do chá gelado, punha assim em cima a fralda ia fumaçando, fumaçando, quando vê a fralda tava sequinha de tão quente que tava o meu peito. $O$ meu peito assim a pele dele saiu tudo assim, ficou na carne viva e eu queria fazer a sessão mais rápido, porque quando a paciente não tá agüentando eles param com a sessão, pra depois voltar, porque é muito sacrificante pra pessoa. Mas a minha filha tava trabalhando, eu falava pro meu genro "me leva todo dia, me leva todo dia porque eu quero acabar", aí eu vinha o médico falava pra mim "você tá agüentando C?" - o médico daqui foi muito bom, falou pra mim "C se você não agüentar você pode falar, não tem problema nenhum? A gente interrompe o tratamento depois continua, a gente não quer judiar de você, a gente vai tratando de você aos poucos". Aí eu falava "não, eu to aguentando, eu to agüentando", na carne viva, aí um dia ele olhou falou assim pra mim "não, você não tá agüentando não, nós vamos dar uma semana de descanso, depois você volta a fazer, você não tá aguentando, você tá querendo agüentar, mas você não tá aguentando. Olha pra você ver a situação do seu peito." Aí eu peguei e falei pra ele "é dr. dói muito mesmo e queima muito mesmo, eu sinto queimar de dentro pra fora, parece que tá pegando fogo de dentro pra fora". Ele pegou e falou assim "então $C$ é isso que 
eu te pergunto, que você tem que me falar, certo?". Aí eu peguei e falei "pois é dr., mas eu quero terminar logo", aí ele falou assim "não, você vai terminar". Aí eu descansei uma semana só e continuei, continuei e foi indo até o fim. Mas eu acho que o paciente... e também eu mudei muito, eu era uma pessoa muito melhor, eu acho.

\section{E. Como assim?}

C. Assim antes eu pensava em todo mundo e não pensava em mim, primeiro eu atendia todo mundo, que eu tenho uma mãe, eu tenho uma filha, eu pensava primeiro em todo mundo, em marido, em filho, em mãe, pra depois eu pensar em mim, certo? Eu era a última pessoa a ser... Hoje não, depois que eu tive esse câncer é eu primeiro depois que vem os outros, certo? Depois que eu tive esse câncer assim eu penso assim, ah pode falar o que quiser, o que eu acho que é bom pra mim é o que eu vou fazer, o que é bom pra mim é o que eu vou fazer, eu não importo o que os outros falam, o que os outros pensam, certo? Eu quero eu viver bem, certo? Os outros não me interessa... Então eu acho que eu mudei muito assim, eu me sinto assim eu era bem melhor, assim hoje eu me sinto bem pior...

C. É... eu acho assim, hoje em dia se a pessoa...assim eu não procuro agradar ninguém, antigamente eu preocupava se eu tava falando alguma coisa pra te ofender, que eu não podia te ofender, que eu não podia... certo? Que eu tinha os princípios, hoje em dia eu não tenho princípio nenhum, hoje em dia o meu princípio sou eu mesma, eu quero agradar eu mesma, eu quero viver eu mesma. Porque eu me senti assim na hora da morte, assim sem merecer e acontecendo o pior comigo, foi terrível pra mim. Assim, então falar não adianta nada a gente ser boazinha, não adianta nada a gente ser honesta, não adianta nada a gente fazer tudo certo na vida, porque o pior acontece com a gente. Então foi isso que ficou na minha cabeça, sabe? Então não adianta, a gente tem que obedecer a Deus e amar ao próximo como a si mesmo, e tudo bem, mas eu falei não adianta, o negócio é eu mudar meu sistema de vida, o negócio eu quero agradar agora só eu, certo? Os outros não me interessa. Larguei do meu marido de 70 anos, arrumei um rapazinho novinho, certo, todo mundo pergunta se ele é meu filho, os outros falam "nossa, ele quer seu dinheiro, ele quer...", não me interessa, me interessa que eu to bem. Você tá entendendo? Se fosse antigamente eu não fazia isso, eu não aceitava, eu 
ouvia o que os outros falavam. Hoje eu não escuto, a minha mãe já acostumou, a minha mãe fala "nossa, mas como você ficou diferente", minha filha "mãe...". Eu falo "eu quero é viver" porque sabe lá se amanhã volta o câncer. Porque muita gente volta e a pessoa morre, falei "se voltar, se eu morrer, minha filha, eu quero viver agora, os dias que eu tiver, satisfeita". Então eu vivo satisfeita, eu saio, eu passeio, se eu to na casa da minha filha se eu to satisfeita eu fico, se eu não to, se tem qualquer coisa que me contraria eu já ó, certo? Na casa da minha mãe é a mesma coisa, se eu to bem... na minha casa se ta ruim eu saio também, dou minhas voltas. No serviço a mesma coisa, no serviço eu sou encarregada de sessão, então eu ficava com aquilo na cabeça, tudo, hoje não, eu dou uma volta na hora, se a pessoa não faz o que eu quero eu dou suspensão, fica dois dias sem trabalhar, eu assino advertência, eu não to nem aí. Então não fico assim sofrendo com aquilo que a pessoa me faz, hoje em dia eu não sofro com nada, hoje em dia eu dou o troco na hora, não quero saber mais se eu to agradando, se eu to desagradando, eu quero agradar a mim e à Deus que eu respeito, mas o resto...o resto pode falar assim o que quiser "ah essa roupa não tá boa", se eu achar que tá eu vou ficar com ela. Eu não era assim...

E. Você levava muito em consideração a opinião das pessoas?

C. É...eu era muito... a minha mãe fala pra mim "nossa, você era tão legal C, você nem falava quando os outros te maltratavam, falavam alguma coisa pra você, você ficava calada, guardava só pra você e na maior educação do mundo você transmitia aquela coisa ruim e coisa boa". Se você falasse pra mim "você não pode falar isso", eu falava pra você "nossa, me desculpa, eu não vou falar mais". Hoje eu falo pra você "eu falei e repito e assino embaixo, certo? Se você não gostou é problema seu, porque eu falei e tá falado e repito". Eu não era assim, eu fiquei assim, às vezes eu até tento melhorar, mas não tem jeito... Eu mudei muito, a doença me mudou muito e não é só eu não. Tem um encarregado amigo meu que a mulher dele teve câncer, ela era uma maravilha, ele falou a mesma coisa, que hoje ela é totalmente diferente.

E. É mesmo?

C. A outra também que tem câncer o marido falou a mesma coisa "nossa, minha mulher, não tinha mulher pior no mundo, hoje em dia eu já não falo 
assim, certo, que hoje em dia o que ela quer ela quer, o que ela não quer ela não quer".

E. Mudam os valores, né, as pessoas começam a prestar mais atenção em coisas que não prestavam antes...

C. Não é? Então isso aí mudou muito na minha vida, isso mudou...

E. E com a família, com os amigos, você acha que mudou o seu jeito?

C. Mudou tudo, eu era muito mais meiga, mais atenciosa, mais carinhosa. Hoje se você conversar muito eu não quero ouvir, certo? Antigamente eu ouvia todo mundo, eu ajudava todo mundo, eu pensava mais nos outros do que em mim, certo? Hoje em dia eu não sou assim mais, hoje em dia não me interessa, porque o pior eu já passei e posso passar de novo, então não me interessa. Antes se você tivesse um problema eu queria ajudar, hoje eu quero ver se eu tenho condição de ajudar, se eu não tiver, eu fico na minha. Eu acho que eu piorei muito.

E. Mas está vivendo melhor, não é?

C. Eu acho assim que hoje eu faço o que eu quero, antigamente eu fazia o que os outros queriam, pra mim que eu achei... Meu sogro morreu de câncer no estômago, meu sogro tinha matado um homem e tudo, eu falava pro meu marido, pai da minha filha, "eu vejo que quem tem câncer é só gente que foi muito ruim pros outros, né, que foi muito ruim pros outros então tem essa doença e fica sofrendo, sofrendo pra morrer", igual meu sogro que levou três anos pra morrer, queria morrer e não morria e sofrendo, sofrendo, e tomando morfina e com dor e tudo, passou a não falar, passou a não alimentar, só alimentava por sonda. Então eu falava pro meu marido "toda pessoa que é muito ruim sofre muito pra morrer". Depois quando aconteceu comigo eu falei "quer saber de uma coisa, eu nunca fui ruim e tá acontecendo, agora eu tenho que mudar. Porque eu nunca desejei mal pra ninguém, nunca roubei, nunca matei, nunca fiz nada errado e tá acontecendo comigo?" Então já não é mais como eu penso a vida, que a vida eu penso assim, se você planta o bem, você tem que colher o bem, se planta o mal você tem que colher o mal. Eu só plantei o bem e to colhendo o mal, aí eu já mudo de vida, certo? Aí eu vou plantar do jeito que eu colho, certo? Aí eu mudei a minha cabeça e não sou só eu não, toda mulher que eu converso que teve câncer mudou muito. Às vezes entendia quando o marido tinha outra na rua, hoje não entende mais, hoje é assim sujou 
levou. Então é assim, descobre, essa mulher lá, o marido muito bem de vida tudo, ela sabia que o marido tinha amante tudo, continuava com o marido, hoje ela fala pra ele "se eu descobrir você sai de casa". Ela tem um filho médico, uma filha dentista, ela fala pra mim "C se eu descobrir ele vai ter que sair de casa", ele... acabou com as farra dele na rua, certo? Mas foi depois do câncer e ele fala pra mim "nossa, minha mulher mudou muito, você mudou também C?". Eu falo "uai, acho que foi a doença que perturbou a cabeça nossa, mexeu..." Mas eu acho que mudou muito a minha cabeça, muito mesmo. Eu tenho uma filha só, minha filha era tudo que eu tinha na vida, mas tudo, eu vivia em função da minha filha, hoje eu falo pra ela "você tem que viver a sua vida, você já formou, você é uma advogada, você tem que viver a sua vida, eu tenho que viver a minha, você tem seu marido, seu filhinho, você tem que viver bem", "ah mãe, mora comigo", "eu não, eu quero ter a minha casa, meu canto". Antigamente se falasse uma coisa dessa pra mim, nossa, eu ia correndo pra casa dela, hoje eu já penso diferente. Então eu acho assim, o câncer me judiou muito, me mudou muito, me judiou muito e assim, eu sou bem diferente do que eu era, e todas mulher que eu convivo que sofreu a mesma coisa que eu sofro, é a mesma coisa, mudaram muito e elas também acham que foi pra pior. Hoje nem os filhos é como era, porque a gente idolatrava os filhos, Deus no céu e os filhos na terra, hoje em dia a gente sabe que se a gente morrer os filhos vai ficar aí. Então muda muito, mexe muito com a cabeça, eu acho que a coisa mais certa que tem é quando a gente passa pelo psicólogo que tenta orientar a gente, fala com a gente, a gente não escuta nada porque a gente já ta na pior mesmo, mas aquilo ali já é uma ajuda boa pra gente, é um meio... Que quando eu vim, a primeira vez que eu passei na psicóloga, a psicóloga falou pra mim " a sra. é casada?", eu falei "sou", "tem uma filha só?", eu falei "tenho", "a sra. vive bem com o marido?", eu falei "'não". Aí já comecei assim "o meu marido é muito sem vergonha, ele não me respeita e não vive bem não, mas é o marido que eu casei, casei na igreja, saí da casa da minha mãe, tudo certinho. Eu não largo dele porque...casei com ele, a gente é família, tudo certo...". Aí ela conversou, conversou comigo, daí falei "quer saber de uma coisa...", aí ela falou assim "ah, a sra. tem que ter qualidade de vida...não sei que tem...não sei que tem", aí eu fiquei pensando: a primeira qualidade de vida que eu tenho é meter o pé na bunda dele (risos), porque a minha qualidade de vida vai subir, 
porque as contrariedade que eu passo e a tristeza que eu passo eu não vou passar mais, certo? Eu posso me sentir solidão, eu posso me sentir sozinha, mas eu não vou ter as raivas que eu tenho de esperar chegar em casa e não chegar, de ver no carro outra mulher né. Aí falei "ah não, isso aí não vou sentir mais né", aí aquilo ali foi mudando, foi mudando, eu fui fazendo e fui achando bom, eu fui mudando e fui achando bom, aí aquilo foi virando aquela bola de neve. Agora hoje eu penso, eu queria ser como eu era e não consigo mais, certo? Assim de vez em quando em penso nossa eu podia ser igual minha mãe, minha mãe tem 85 e fala "nossa, agora não pode nem falar as coisas pra você que você fala na hora, antes você aceitava tudo, agora nem pode falar as coisas pra você que você não aceita". Aí eu falei pra minha mãe "nossa, eu tinha uma vontade de ser igual eu era...".

E. Você acha que antes você era muito tolerante, e agora nada tolerante?

C. É... eu falei pra minha mãe "eu tinha vontade de ser como eu era, mas eu não consigo, eu não consigo ser como eu era muito legal, mas muito legal mesmo, hoje eu não sou mais, não é porque eu não quero não, é porque a minha cabeça mudou mesmo. Tem hora que eu acho que o sofrimento fez eu passar pra outra etapa da minha vida, assim uma coisa que eu achava que nunca ia acontecer, que podia acontecer com todo mundo, menos comigo, certo, porque eu não merecia aquilo lá. A primeira coisa que eu fiquei falando, falando sem parar, e eu chorava, chorava e falava assim "mas eu não mereço isso, eu não mereço isso", eu comecei assim. Aí minha filha falou "mãe, vou levar a sra. no psicólogo, mãe vou tratar de você, da sua cabeça", eu chorava, as lágrimas saiam sem querer assim, aí eu falava pra minha filha "mas eu não mereço isso, eu nunca desejei mal pra ninguém, nunca fiz mal pra ninguém, como que uma coisa dessa foi acontecer comigo, né, tem que acontecer com quem planta, eu nunca plantei maldade, nunca fiz nada né, eu só tinha que colher coisa boa". Aí chorava, e chorava, nossa Deus, foi muito difícil... Aí aquilo foi ficando na minha cabeça, eu fui achando que não compensava, que a vida que vivia não compensava, e hoje eu tento ser como eu era e não consigo mais, não consigo, porque hoje eu sou o que eu sou. Os outros goste ou não goste, ache bom, ache ruim, eu sou o que eu sou, então assim também hoje sou muito diferente do que eu era, às vezes eu tenho vontade de ser um pouquinho do que eu era, assim, mas não consigo mais. Isso aí foi o câncer 
que me fez isso e não é só eu não, as mulher tudo que eu converso que teve câncer tudo é assim, mudou muito o jeito de ser. Tem mulher que era bem tolerante, hoje não é mais, que era tolerante com os filhos, com o marido, com tudo e hoje não é mais... acho que o sofrimento é muito grande...

E. Com certeza, muda muito a pessoa.

C. Aí a pessoa fica muito cheia de problema...

E. A pessoa vê as coisas de outro jeito, passa por tudo isso...

C. É, hoje não me interessa o que os outros pensam, interessa o que eu penso. Hoje não me interessa se a pessoa fala pra mim "nossa, mas você arrumou um homem que dá pra ser seu filho". Eu fui comprar uma roupa pra ele a mulher falou assim "nossa, o seu filho ficou bem", aí eu falei pra ela "não é meu filho, é meu marido", eu falo assim, coisa que eu não falava, se fosse antigamente eu não falava, ficava calada, eu ficava quieta e guardava só pra mim, hoje eu falo "quem que é meu filho? É meu marido, também não to tão acabada assim não" (risos), então eu falo na hora.

E. Hoje em dia é tão natural relacionamento com diferença de idade.

C. E eu não era assim, hoje em dia se me agrada bem, se não agrada também eu falo, não tem mesmo, tem hora que eu fico pensando "gente, como é que uma pessoa pode mudar desse jeito como eu mudei" certo? Eu mesmo fico pensando como eu fui mudar tanto, mas é assim, não consigo ser como eu era antes, não sei se o sofrimento mexeu muito com a minha cabeça...

E. E agora nessa reta final, como está se sentindo?

C. Eu me sinto bem graças a Deus, sem problemas, sem problemas. Tenho muito medo do câncer voltar, muito medo mesmo, peço a Deus que não volte, mas assim eu tenho medo porque o câncer é uma doença muito ruim, então eu morro de medo, mas hoje eu já conformei que o câncer é hereditário, eu tive uma tia que morreu de câncer, eu tive um tio que morreu, minha mãe não, minha mãe tem 85 anos e nunca teve nada. Mas eu assim, eu tenho medo, eu tenho medo, mas eu confio em Deus, como menos carne, como mais verdura, como mais fruta, e assim levo a minha vida mais... coisas assim... Mas a gente tem medo. Hoje em passei pelo médico, pelo dr W, ele falou "você tá bem, tá terminando seu tratamento, eu tenho uns colegas lá na sua cidade que pode tratar lá", eu falei pra ele "não eu trato aqui, eu continuo é aqui até terminar". Minha filha ficou assim, porque foi meu médico desde o início, mas aí tá 
pensando que eu vou falar "não, eu aceito o seu colega", eu falei na cara dele na hora "não, eu vou continuar aqui, eu vou terminar aqui e tudo bem". Ele ficou caladinho, não falou nada, mas a minha filha começou a olhar assim pra mim como quem diz "mãe, manera", que manera o que, eu falei na hora "vou continuar aqui sim até terminar, tá bom?" "Tá". Aí passou mamografia, passou outro exame lá pra eu fazer, falei "eu vou fazer e mandar trazer pro sr.", ele falou "não, to te falando porque agora fez o Hospital do Câncer lá na sua cidade, então o pessoal da minha equipe que trabalha aqui comigo tá lá, então to te falando assim que se você precisar eu te dou o nome do dr.fulano, dr. sei lá, parece que $\mathrm{N}$, eles te atendem que eu falo que você é paciente minha, eles te atendem". Eu falei "não, eu vou ficar aqui mesmo, vou terminar meu tratamento aqui", aí também ele não falou mais nada não.

E. Talvez ele achou que pra você fosse mais fácil pra não ficar viajando.

C. É, ele quis me ajudar, mas você tá entendendo? Eu mesmo sou assim, eu poderia falar "ah tá o sr. vai escrever um bilhetinho pra eles me atender ou eu posso usar o nome do sr.lá, falar que o sr.mandou eles me atender, né, como é que eu faço?", eu falei "não, ixi, eu vou contiuar aqui, tudo bem, vou terminar meu tratamento aqui". Minha filha ficou olhando assim como quem diz "manera mãe".

E. Tem mais alguma coisa que você acha importante me contar dessa história? C. Ah, a minha história é essa mesma que eu te falei, é que a gente muda um pouquinho pra pior, certo? Mas é a vida né... E a gente quer voltar do jeito que era, não volta, então não adianta que não volta, às vezes a gente até tenta tem hora assim ser mais tolerante, ser mais... certo? Mas não consegue, parece que é uma coisa assim que passou, passou uma etapa da sua vida, você entrou em outra e na outra etapa que você entrou não tem jeito de você voltar atrás, você tem que seguir em frente. Então é o que acontece comigo, e as outras que teve o problema sempre fala isso também, que mudou muito a vida, que mexe muito com a cabeça da mulher né.

E. Eu tenho ouvido muitas histórias assim mesmo.

C. Não é? É porque sei lá... Eu também acho igual assim uma família que sofre um acidente muito grande e muita gente da família morre, a pessoa acho que nunca mais vai viver igual, quando entra no carro já preocupa, quando vê outro 
acidente já fica desesperado, eu acho que é uma coisa assim que já é da própria vida mesmo, só isso... o resto... 
APÊNDICE C - Sínteses das histórias

História de Clarita

Clarita tem 59 anos, trabalha como encarregada de sessão em uma usina de açúcar em uma cidade no interior de MG, é divorciada e mãe de uma filha de 38 anos.

Clarita não tinha caroço no peito, tinha uma pintinha muito pequenininha, foi fazer uma mamografia de rotina, achava que estava vendendo saúde, e achou um nódulo, mas a médica disse que não era câncer, que não precisava retirar. Clarita foi então em um médico particular e pediu para retirar o nódulo e fazer biópsia. Durante a cirurgia o médico ficou na maior alegria, falou que tinha descoberto o câncer, Clarita chorou. $O$ médico disse que seria preciso retirar o peito inteiro, senão o câncer se expandiria em trinta dias. Clarita sentiu um mal estar maior do mundo naquela hora. A filha de Clarita exigiu a lâmina que comprovasse o diagnóstico de câncer para levarem em outro laboratório, onde foram feitos todos os exames. Clarita e a filha procuraram outro médico e este confirmou o diagnóstico de câncer que ainda estava no princípio. Foi feita então uma nova cirurgia com retirada de apenas um quadrante da mama e Clarita fez todo o tratamento.

Clarita acha que a pior doença que existe é o câncer, porque não dá sintoma, vem traiçoeiro, caladinho e quando recebe é a pior notícia do mundo. $O$ tratamento judia muito, os remédios são muito difíceis, a radioterapia queima muito. Durante as sessões de radioterapia a filha de Clarita punha chá de camomila gelado no local da radiação que ficou na carne viva, e mesmo assim Clarita não queria interromper o tratamento, queria acabar logo e pedia para o genro levá-la todos os dias. Sentia queimar de dentro para fora, parecia que estava pegando fogo.

Clarita mudou muito após o câncer, achava que o câncer podia acontecer com qualquer pessoa menos com ela, pois nunca havia desejado mal a ninguém, nunca havia feito mal a ninguém e sempre foi uma pessoa muito boa. O que Clarita passou, não deseja a ninguém, o câncer é como uma sentença de morte com prazo curto. Antes de ter o câncer, Clarita pensava em todo mundo e não pensava nela, aceitava o que os outros falavam, era muito mais meiga, 
mais atenciosa, ajudava todo mundo. Após o câncer, Clarita quer viver bem e satisfeita, pensa primeiro nela, depois nos outros, não se interessa pelo que os outros pensam ou falam, não procura agradar ninguém. Não adiantou Clarita ser boazinha, ser honesta, que o pior aconteceu com ela, então o negócio foi mudar de vida. Largou o marido de 70 anos e arrumou um rapazinho, faz o que quer e não o quê os outros querem.

Clarita acha que mudou para pior, tinha vontade de ser como era, mas não consegue porque a cabeça mudou mesmo. Tem medo do câncer voltar, mas confia em Deus e cuida mais da sua vida.

\section{História da Anali}

Anahi tem 48 anos, é professora, é casada, tem um filho de 21 anos e mora em Ribeirão Preto.

Quando Anali ficou sabendo que estava com câncer foi um choque, no primeiro momento não aceitou, chorou muito. Estava desempregada, seu marido ganhava pouco e estavam endividados. Anali procurou uma psicóloga que a ajudou muito, depois veio a aceitação e decidiu que faria tudo que fosse preciso para se curar.

Anali pediu a Deus que ainda queria ver seu filho, seus netos e foi à luta. Passou pela cirurgia, pela radioterapia e depois pela quimioterapia que foi muito difícil, ficou ansiosa antes da primeira sessão de quimioterapia, pois não sabia como seria. Ficou nove meses em casa de repouso.

Com a doença, Anali aprendeu a viver um dia após o outro, percebeu que a vida não é só pensar em si própria. É uma pessoa que consegue superar suas dificuldades. Anali ficou mais sensível, consegue perceber quem realmente são seus amigos e as pessoas com que pode contar.

O relacionamento de Anali e o marido melhorou muito, eles ficaram mais unidos, mais companheiros. O marido esteve presente o tempo todo a ajudando a resolver tudo, dava banho, limpava a casa.

$\mathrm{Na}$ perícia médica, tentando retomar sua atividade como professora, Anali levou um baque quando o médico disse para ela não aparecer durante dois anos, que não teria o atestado, pois a doença poderia voltar. Anali ficou uns três anos sem trabalhar e o quê ajudou foi o dinheirinho que conseguia com 
vendas. Em 2008 pegou um monte de aulas e hoje está com 25 aulas por semana em Ensino Fundamental e Médio. Tem horas que Anali pensa em desistir das aulas, mas tem medo de se arrepender, assim como quando ela trabalhava no banco e parou. Anali gosta de dar aulas, mas aprendeu a reconhecer os seus limites, sabe que não consegue dar mais do que 25 aulas por semana e quando está doente não vai trabalhar.

\section{História de Cristine}

Cristine tem 52 anos, é enfermeira, é casada, mãe de um filho de 25 anos e uma filha de 23 anos.

Casou-se aos 24 anos, logo após se formar e ainda é apaixonada pelo marido. Trabalhou 10 anos na unidade de queimados do Hospital das Clínicas, depois foi pra ortopedia do campus ser diretora de serviço.

O câncer apareceu em 2002 de forma suave, não parecia que Cristine tinha ficado doente, não sentiu o impacto, uma semana após a cirurgia Cristine teve alta e já estava trabalhando. Quando o câncer voltou, em 2006, tudo mudou. Fazer a quimioterapia foi muito sofrido, um mal estar inexplicável. Teve a questão da morte, do corpo, Cristine ficou sem mama e com uma cicatriz grande, perdeu o cabelo e, com isso, vieram as mudanças. Cristine fala que há apenas dois caminhos, como em uma encruzilhada: sentar e chorar ou erguer a cabeça, seguir em frente e tirar proveito do que tem de bom. Não fosse pelo câncer Cristine não seria salva, fazia muita coisa errada, não respeitava o momento das pessoas, era nervosa, estressada, tensa, não se cuidava, não se alimentava, não se preocupava consigo, não estava bem em lugar algum. Com os filhos também era tensa, brava, se irritava por qualquer coisa. Sempre teve problemas de relacionamento com a mãe que sempre foi muito insegura, medrosa e amargurada. Cristine ficou afastada do trabalho, teve tempo para pensar e fez uma reflexão de vida. Leu muitos livros, percebeu que tinha que mudar por dentro, uma mudança mental, espiritual. A religião foi um suporte fundamental para Cristine e ela também teve apoio psicológico.

Houve uma transformação na vida de Cristine que atualmente é uma pessoa muito religiosa, católica, apaixonada por Jesus, mais tolerante, tem mais equilíbrio, não entra mais em briga se não valer a pena. $O$ medo de morrer, 0 
medo de olhar para traz e não ter sido como gostaria, assim como um milagre de Deus deram à Cristine uma nova chance de mudar de vida. A relação com os filhos, com a mãe e com o marido melhorou. A filha ajudou muito, no momento que Cristine teve o câncer, e isso as uniu. A relação com o marido também foi fortalecida, ele ficou com medo de perdê-la, ficou mais carinhoso, ficaram mais unidos.

Cristine após o câncer se arruma mais, compra roupa, se veste bem, se cuida, participa do REMA. Tem medo da recidiva, mas procura não ficar sofrendo por antecedência, não fica pensando no que passou e no que vai acontecer pra frente. $O$ resultado final foi bom, Cristine cresceu demais com tudo isso.

\section{História de Florentina}

Florentina tem 58 anos, é secretária em um colégio de freiras, é casada, mãe de dois filhos, um de 27 anos (falecido) e um de 33 anos.

Florentina descobriu que estava com câncer quando realizou exames, aconselhada pelo médico de sua mãe, que estava em tratamento de câncer. No primeiro momento, após confirmado o diagnóstico, levou um susto muito grande, pensou que ia morrer, mas depois foi se acalmando e entendendo. Passou por três cirurgias na mama, sendo a última uma mastectomia radical. No hospital, após a última cirurgia, Florentina ficou muito feliz com as visitas, quis se arrumar, estava com um curativo enorme, mas não sabia como estava por baixo do curativo. Em casa, durante o banho, tirou o curativo e quase desmaiou, gritou, precisou sair embrulhada chamando a vizinha que é enfermeira. Florentina passou mal, ficou fraquinha, geladinha, amarelinha, sua pressão caiu, estava tudo roxo no local do corte, cheio de pontos. Ainda com poucos dias após a cirurgia, Florentina pediu que o médico a liberasse para participar da formatura de seu filho caçula em uma outra cidade.

No primeiro ano Florentina confiava desconfiando, ficou com muito medo, precisou tomar antidepressivos e remédio para dormir. É uma pessoa muito otimista, de muita fé, em momento algum se sentiu revoltada, gosta de estar muito próxima de Deus, sente-se bem assim. 
Florentina gosta muito do colégio onde trabalha há 21 anos e onde seus dois filhos estudaram.Teve uma força interior muito grande, procurou ler bastante para conhecer sobre a doença, ficou mais fortalecida e continua firme em sua caminhada.

Em 2007 Florentina perdeu seu filho mais jovem que era professor, ator e diretor de teatro. Foi horrível, pior que o câncer, mas passou, não foi fácil. Precisou voltar a tomar os antidepressivos e remédios para dormir. O marido, a mãe, os filhos, as irmãs, os sobrinhos, enfim, toda a família ajudou muito. A diretora do colégio também ajudou muito Florentina, levantando sua autoestima, assim como as outras irmãs e funcionários, extensão da sua família.

Florentina ficou mais sensível, mais humana e mais voltada para o ser humano, mais cuidadosa, com mais vontade de viver. Presta atenção em coisas pequenas que a fazem feliz. Quando ouve alguém dizer que está com câncer, fala para a pessoa levantar a cabeça e olhar para a sua história, um exemplo de vida. Florentina cuidou de duas primas que tiveram câncer, assim como seu avô e pai também tiveram.

Florentina é muito alegre, adora viver, ama as pessoas, ama trabalhar. Nunca desistiu, não pensou que iria morrer pelo fato de suas primas terem morrido, achou que ia dar tudo certo.

Pra quem está passando pelo câncer, Florentina recomenda: se informar, não ter medo, ser alegre, otimista, participar do REMA, não se fazer de vítima.

História de Juliana

Juliana tem 52 anos, é ex-bancária, é casada, mãe de uma filha de 22 anos e um filho de 20 anos.

Juliana gostaria de descobrir por que teve o câncer, não acredita que seja hereditário.

Quando Juliana tinha dez anos seu pai faleceu em um acidente. Eram nove filhos, a mãe e os filhos mais velhos ficaram trabalhando na fazenda enquanto Juliana e os outros irmãos foram morar na cidade. Juliana sempre sentiu muito a ausência dos pais, não achava normal morar sem eles, tentou sobreviver 
nessa época, ninguém entendia porque ela chorava. Juliana tomava conta da casa e de alguns irmãos, viveu assim dos dez aos 22 anos. Quanto estava com 22 anos sua mãe foi morar na cidade, mas Juliana não conseguia mais morar com a mãe, foi embora pra São Paulo.

Juliana foi morar com a sua prima, passou no concurso de um banco, conheceu um amigo do seu primo e começaram a namorar. O namorado era de Ribeirão Preto e após um tempo de namoro Juliana decidiu se mudar para Ribeirão, então ficaram noivos e depois se casaram. Juliana conseguiu a transferência do banco, onde trabalhou por 22 anos. Ela e o marido sempre faziam tudo que tinham vontade, sempre foram muito independentes. Juliana optou por trabalhar meio período no banco, após duas tentativas de subir de cargo que the puxaram o tapete. Decidiu que estaria mais presente na vida dos filhos, já que sentira muita falta da mãe e do pai por não ter podido morar com eles. Juliana sabia que em algum momento seria mandada embora do banco, mas a forma como isso aconteceu, a administrativa foi tão curta e grossa, que Juliana acha que isso pode ter the causado o câncer, foi a pior coisa que aconteceu em sua vida.

No Natal do ano seguinte Juliana percebeu uma secreção no seio. Ela tinha feito seu currículo, correu atrás de tudo quanto é $\mathrm{RH}$ e o que pesava era a idade, a experiência não valia nada. De fevereiro de 2004 até o final de 2005 Juliana ficou ruim, tinha perdido o emprego, perdido os amigos, queria trabalhar, mas não conseguia superar o problema.

Juliana foi ao ginecologista que pediu que fizesse vários exames, o mundo virou, desabou tudo. Juliana não imaginava como era o câncer e o tratamento, foi encaminhada a um oncologista. Na primeira quimioterapia passou muito mal e após 20 dias seu cabelo começou a cair, então pediu ao marido que a levasse para raspar a cabeça. Nas sessões seguintes Juliana não passou mal, pois o médico havia lhe passado uma medicação.

A família de Juliana cuidou dela durante o tratamento, no mesmo ano sua filha passou no vestibular e foi morar em outra cidade. Após a segunda quimioterapia e sentindo-se bem, Juliana decidiu fazer um teste vocacional, mas a psicóloga disse que ela precisava de um acompanhamento psicológico. Fez por três meses e parou, pois teve que fazer a mastectomia e também repouso. Continuou o tratamento aos trancos e barrancos, tinha muita ferida 
nos braços, na boca, a pele sempre muito seca. O marido ajudava nos banhos, nos curativos, acompanhando nas 36 sessões de radioterapia.

Durante quase dois anos Juliana recebeu seguro doença do banco. Depois foi convidada por um amigo para trabalhar com negócio de site, onde ficou nove meses. Posteriormente uma colega a convidou para trabalhar com eventos, ficou apenas 25 dias, substituindo uma funcionária que estava em férias. Então Juliana conheceu o REMA onde começou a fazer exercício, terapia de grupo, fez novos amigos.

O câncer, para Juliana, foi o resultado de coisas que foram juntando, e que teve que explodir. Antes Juliana queria trabalhar, ter um monte de coisa, mas sabe que sem a saúde não vai valer nada. Hoje Juliana sabe o que quer, sabe dar outros valores, sabe se cuidar melhor.

Juliana hoje é feliz, sabe que se vier o câncer de novo vai enfrentar com a mesma coragem, porque sabe que o dia de cada um está marcado.

História de Lorena

Lorena tem 66 anos, é contabilista, é solteira.

Quando tinha sete anos Lorena perdeu o pai que era seu ídolo e aos 19 anos perdeu a mãe doente, cuidando da mesma até seu falecimento. Lorena descobriu um caroço em sua mama em autoexame e foi confirmado diagnóstico de câncer após passar por ultrassonografia e biópsia. Lorena estava preparada quando recebeu o diagnóstico de câncer, pois já havia tido casos na família. Foi encaminhada ao oncologista, passou por cirurgia e na recuperação pegou o rota vírus, precisando ser reinternada por vários dias. Passou muito mal. Após a retirada dos drenos, Lorena ficou com o braço muito inchado e com muita dor, precisando fazer 100 sessões de fisioterapia para que o braço voltasse ao normal. Lorena faz os exercícios indicados pela fisioterapeuta diariamente. Passou por 12 sessões de quimioterapia e no meio do tratamento quase desistiu, estava com a boca cheia de úlceras, conseguia se alimentar apenas de sopas e sucos, mas decidiu continuar, se parasse perderia todo o tratamento que já havia feito até o momento. Quando faltavam duas sessões de quimioterapia Lorena entrou em uma igreja e pediu a Deus 
que a ajudasse a terminar as sessões. Depois da quimioterapia Lorena passou pela radioterapia. Quando teve alta, Lorena caminhou pelo centro da cidade e se perguntava se era ela mesma que estaria ali viva depois de passar por cirurgia, quimioterapia e radioterapia. A emoção foi tão forte que Lorena ficou na sombra de dúvida, foi para casa e falou pra irmã que o mundo tinha caído, mas que ela tinha sobrevivido. Então foi até o quintal, abriu a mangueira, colocou todos os sapatos que estavam em uso no chão deixando a água escorrer lavando-os.

Durante todo o tratamento Lorena recebeu uma força muito grande da sua irmã, que é seu anjo da guarda e estão juntas há 62 anos. Quando ficou sabendo de seu diagnóstico, Lorena contou apenas para esta irmã e para o irmão. Lorena sofreu, mas não se sente infeliz por ter tido um câncer, considera a doença como um dragão que é preciso enfrentar e faz assim com todas as coisas de sua vida. Acredita que o mérito é de todos, dela, da irmã, do irmão, do médico, da fisioterapeuta e é preciso estar preparada e ter força de vontade para se curar, não deixar a doença atingir o emocional. O câncer é para Lorena uma lição de vida, ela é uma vencedora, agora mais fortalecida com o final de tratamento e como quem está para ganhar um troféu.

História de Marina

Marina tem 54 anos, é secretária, é casada, mãe de dois filhos, um de 23 anos e um de 21 anos.

Marina estava voltando de férias da praia e percebeu uma alteração em seu mamilo. Foi procurar um amigo ginecologista que a encaminhou a um mastologista, que por sua vez encaminhou-a a um oncologista. Aí o mundo de Marina caiu. Os filhos dela tinham na época 17 e 16 anos e o marido trabalhava em São Paulo. Marina passou por biópsia e antes de ter o resultado do exame já havia pesquisado e descoberto sobre o seu tipo de câncer. Quando o médico Ihe falou sobre o resultado, o mesmo ficou espantado ao ver que Marina já tinha conhecimento do diagnóstico. O médico falou que ela precisava fazer uma cirurgia e no momento ela disse que tudo bem, mas quando saiu do consultório foi que a ficha caiu e Marina desaguou. 
Marina contou ao marido e aos filhos que estava com câncer, então todos começaram a chorar, mas ela sabia que precisava criar forças. Passou por outro médico e outra biópsia, que confirmaram o diagnóstico, então decidiu que faria a cirurgia, mas só depois de dois casamentos em que seria madrinha. Marina não se deixou abater, fez a cirurgia e no dia seguinte já estava em casa. Fez o tratamento certinho, a primeira quimioterapia aconteceu na época em que seu filho mais velho estava se formando no colegial, ela foi ao cabeleireiro e seu cabelo começou a cair, teve que raspar a cabeça. Marina usava lenços e fitas de várias cores. Em todas as quimioterapias passava mal durante uns quatro dias, na época sua mãe foi morar com ela. Quando terminou as sessões de quimioterapia Marina levou bolo e refrigerante para comemorar no hospital, havia nascido de novo. Depois foram as 38 sessões de radioterapia e Marina foi abençoada, pois não teve queimaduras.

Marina teve um tio, uma tia e avô paternos que morreram com câncer, mas não sabe se tem algo a ver, não sabe se é genético. O médico acha que com ela foi nervoso e stress e atualmente Marina também passa por isso no trabalho. $O$ marido disse para ela sair do trabalho, já que tem dois filhos e um marido que trabalham.

O que incomoda muito Marina é o fato de ter engordado durante o tratamento, mas por enquanto não consegue fazer dieta, sente muita fome com a medicação. Na família Marina é tratada como se fosse uma pessoa especial, o carinho e o cuidado aumentaram.

Após o câncer Marina aproveita a vida de uma maneira saudável e regrada, passeia, curte mais os filhos, vê a vida de outra forma.

História de Rosangela

Rosangela tem 55 anos, é administradora e artesã, é casada, mãe de um filho de 24 anos e uma filha de 19 anos.

Rosangela resolveu antecipar sua consulta e exames de rotina no ginecologista, estava cismada. O médico pediu exame de ultrassonografia e depois a encaminhou ao oncologista que aconselhou fazer uma biópsia. Após a biópsia Rosangela recebeu o diagnóstico de câncer de mama, levou um baque. 
O marido não estava quando ela chegou em casa, tinha ido buscar a filha na escola, quando voltaram ela contou sobre o câncer. Rosangela passou por cirurgia, quimioterapia e radioterapia. A cirurgia foi tranquila, com a retirada de apenas um quadrante da mama, seguida de cirurgia plástica de reconstrução da mama. Rosangela tem muita fé em Deus, recebeu muito apoio da família e dos amigos. Durante o tratamento Rosangela levava uma vida normal, sua casa estava sempre cheia de amigos, saía de peruca, lencinho, tinha muita disposição. Ouviu muitas histórias e encontrou gente forte, lutando, muitos casos diferentes do seu.

O marido de Rosangela teve câncer de próstata, então a família já estava calejada quando aconteceu com ela, já tinham passado por uma história de câncer e foram tocando com muito amor, com muita felicidade.

Rosangela perdeu uma amiga com câncer, ficou muito abalada, era uma amiga bastante próxima e também sua vizinha.

Depois do câncer Rosangela dá mais valor à vida, não faz mais questão de coisas banais, coisas que antes tinham valor perderam a importância. Sente-se bem, faz ginástica, gosta de música.

História de Silene

Silene tem 71 anos, é viúva e aposentada.

Silene descobriu que estava com câncer a partir de dores que sentia nas costelas, foi ao ortopedista que pediu que fizesse uma mamografia e um raio $x$ do tórax. Silene também pediu ao sobrinho que é médico que a examinasse, encontrando um nódulo no seio e encaminhando-a a um oncologista. Silene fez os exames e vendo os resultados achou que os médicos estavam enganados, que não havia nada de errado e começou a dar graças a Deus, estava muito nervosa. Levou os exames para o oncologista que pediu uma punção para avaliar melhor, já que dava para se notar o nódulo. No exame a patologista não conseguiu puncionar o nódulo, então o oncologista decidiu colher material para fazer uma biópsia e o resultado foi positivo, era um câncer e era preciso fazer cirurgia. Silene passou pela cirurgia com esvaziamento de axila, depois pela pior fase, a quimioterapia, foi uma barra, ficou sem nenhum fio de cabelo, caiu 
tudo, sobrancelha, cílios. Silene que ia ao cabeleireiro toda semana, na época da quimioterapia, pediu que cortasse seu cabelo bem no toquinho, depois passou a máquina zero, foram seis meses, então nasceu tudo de novo. Depois da quimioterapia veio a radioterapia, não sentiu mal estar como na quimioterapia, mas teve queimaduras internas. O oncologista, na última consulta, disse a Silene que procurasse um geriatra para acompanhá-la, mas ela não gostou do jeito do médico, achou muito seco, fez os exames pedidos, confirmou osteopenia, mas não quis voltar, vai procurar outro geriatra.

Silene está levando uma vida muito chata, vive sozinha, perdeu seu marido há dois anos, viveram 11 anos juntos. $O$ marido foi seu primeiro namorado, ela tinha 17 anos e ele 23 quando se conheceram. Ficaram muito tempo separados e se casaram após ele ter tido um derrame cerebral. Silene, há um ano, perdeu também a irmã que vivia com ela e em seguida sua cachorrinha morreu. Ela tem um irmão que não pode ajudá-la, pois é deficiente. Silene ficou muito baqueada com tantas perdas.

Atualmente Silene tem outra cachorrinha que é sua companheirinha, mas não pode contar com ninguém, é sozinha. Faz apenas aquilo que tem vontade e o que seu organismo suporta, vai ao centro, lê, faz uns bordados, conversa com as vizinhas, participa de alguma festinha.

\section{História de Hélia}

Hélia tem 58 anos, é casada e tem um filho de 20 anos.

Hélia fazia exame de mamografia anualmente e sempre dava calcificação isolada. O médico falava pra ela não se preocupar, que apenas seria preocupante se desse calcificação agrupada. Em dezembro de 2004, quando fez o exame, pegou o resultado e viu que a calcificação estava agrupada. Entrou na internet e pesquisou o que estava escrito no resultado da mamografia e a probabilidade de ser um câncer era de $90 \%$.

Quando Hélia chegou ao médico, disse que não precisava esconder nada e que sabia que a chance de ser um câncer era grande. Então foi encaminhada ao oncologista, fez biópsia e quando saiu o resultado perdeu o chão, foi uma sentença de morte. Ficou desesperada, tentou não demonstrar à família, nem 
no trabalho. Hélia fez a cirurgia e tentou fazer passo a passo tudo o que tinha que fazer, pensava e lutava pelo seu filho que na época tinha 14 anos, queria vê-lo crescer, se formar, entrar na faculdade.

Nas sessões de radioterapia Hélia tentava o tempo todo demonstrar que estava bem, fazia todo mundo dar risada, contava piada, o ambiente já era muito pesado e via pessoas em situações piores do que a sua.

Depois Hélia passou pela quimioterapia, mas graças a Deus não the caiu todo o cabelo, não precisou ficar careca. Permitia-se comer, pra poder estar bem, pra poder se tratar e assim não tinha tanto mal estar, tinha que fazer o serviço de casa, cozinhar.

Hélia pegou trauma da palavra câncer, durante três anos não queria que ninguém comentasse a respeito da doença perto dela, não gostava de ouvir de jeito nenhum, nunca disse pra ninguém o que ela tinha, só quem sabia era a família. Muitas noites ela deitava escondido, começava a pensar e chorava.

Atualmente Hélia tem medo, vive em estado de alerta, qualquer coisinha que sente já pensa na doença. $O$ câncer foi uma barreira que Hélia encontrou e teve que ultrapassar.

\section{História de Cleusa}

Cleusa tem 65 anos, é casada, mãe de uma filha de 35 anos. Tem dois netos, uma menina de 14 anos e um menino de 06 anos. Cleusa trabalhou na roça ainda muito jovem, depois morou num convento de freiras por quatro anos. Mudou-se para São Paulo em busca de melhores oportunidades, onde trabalhou numa fábrica de tecidos por dois anos e meio, depois trabalhou no Bradesco, sendo transferida para Ribeirão Preto. Trabalhou no Bradesco até sua filha nascer, depois trabalhou somente em casa.

A sogra de Cleusa teve câncer e Cleusa a acompanhou durante todo o tratamento, vendo-a passar muito mal durante a quimioterapia. Tal fato fez com que Cleusa tivesse muito medo da quimioterapia. Cleusa descobriu seu primeiro câncer, na bexiga, em 1994, quando o marido estava passando uma temporada no Japão. Foi um choque, mas sempre teve muita fé e sentiu que seria capaz de enfrentar o câncer. O marido na época voltou do Japão para 
acompanhá-la no tratamento. Depois em 2006, Cleusa descobriu que estava com câncer de mama, mas desta vez, parece que não sentiu nada, apesar do medo da quimioterapia, não se assustou, ficou tranqüila, passando por cirurgia, radioterapia e hormonioterapia. Em janeiro de 2011, Cleusa quase sucumbiu ao descobrir que estava com câncer no intestino, pois já tinha visto e ouvido histórias de muitas pessoas que não sobreviveram a este tipo de câncer. Foi fazer um ultrassom transvaginal e a médica identificou alteração no intestino. Seu genro e sua filha entraram em pânico, procuraram um médico conhecido e queriam que Cleusa fizesse o pet scam para talvez evitar a cirurgia, mas 0 oncologista disse que no seu caso era preciso operar. A cirurgia do intestino foi de grande porte, Cleusa passou muito mal, tinha que voltar sempre ao hospital, teve os pontos arrebentados o que causou grande sangramento. Ficou desidratada e com gastrite por ficar muito tempo sem se alimentar, por causa dos exames.

Cleusa está tomando Anastrozol, estava tomando Tamoxifeno, mas teve catarata nos dois olhos e precisou operar, devido ao uso da medicação, então esta foi mudada. Fará acompanhamento a cada quatro meses, pois está com um pequeno cisto no fígado.

Cleusa sempre teve muita fé e pensa da mesma forma após ter passado por três diferentes diagnósticos de câncer, quando quer algo vai atrás e tenta seguir de cabeça erguida. Procura sempre ler, ver entrevistas médicas na televisão.

Cleusa sente dificuldade em se relacionar com as pessoas, mas ainda não procurou ajuda para mudar esta situação. Gosta muito de ficar sozinha e muitas vezes faz coisas com o intuito apenas de agradar aos outros.

\section{História de Velma}

Velma tem 51 anos, é casada, veio da região centro-oeste para Ribeirão Preto para fazer tratamento de câncer de mama.

Quando Velma descobriu que estava com câncer foi muito difícil, acreditava que tinha pouco tempo de vida e tentou suicídio. Na cirurgia Velma sofreu uma parada cardiorrespiratória, precisando ficar na UTI. Um mês após a cirurgia, 
começaram as sessões de quimioterapia, na segunda sessão Velma chegou a desistir, achou que mesmo fazendo o tratamento morreria dali pouco tempo. Velma retomou as sessões de quimioterapia e passava muito mal, inchou, engordou, perdeu todo cabelo. Depois com a radioterapia Velma teve queimaduras na pele, usava chá de camomila, mas mesmo assim precisou desistir de algumas sessões.

Durante o tratamento Velma ficou sabendo de muitas pessoas que também estavam se tratando e foram à óbito. Ficou muito mal na época, não saía de casa sozinha, tinha medo de tudo, entrava em pânico por qualquer coisa.

Velma contou com o apoio da família, sua mãe e sua irmã vieram para Ribeirão Preto para acompanhá-la, e também recebeu acompanhamento psicológico.

Há três meses Velma vem fazendo exames, pois foi constatado um novo nódulo ainda não diagnosticado. Velma está muito triste e com medo de passar por tudo de novo, acha que não agüentaria.

A vida de Velma mudou muito após ter passado pelo tratamento do câncer, algumas coisas mudaram para melhor, antes não gostava de ir em hospital, em lar, em creche, agora gosta e participa. Sua forma de se relacionar com as pessoas melhorou, pensava que o câncer poderia acontecer com todo mundo menos com ela e hoje vê que acontece com todo mundo. Velma procura viver sem esperar muito, vive o hoje.

Velma está triste pela possibilidade de passar novamente pelo tratamento do câncer e por estar longe da família neste momento.

Ela ainda terá que tomar a medicação (hormonioterapia) por mais um ano, sentindo muito calor em alguns momentos e em outros, muito frio, sente-se nervosa.

Está aguardando finalizar os exames para poder decidir o que fazer. 


\title{
ANEXO A - Aprovação do Comitê de Ética em Pesquisa
}

UNIVERSIDADE DE SĀO PAULO

ESCOLA DE ENFERMAGEM DE RIBEIRÃO PRETO

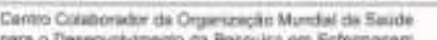

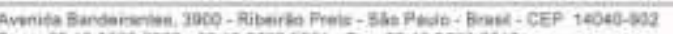

Fan es 103602 iste

COMITÊ DE ÉTICA EM PESQUISA DA EERP/USP

Of.CEP-EERP/USP - 082/2011

Ribeirâo Preto, 07 de abril de 2011.

Prezada Senhora,

Comunicamos que o projeto de pesquisa, abaiko especificado. foi analisado e considerado APROVADO AD REFERENDUM pelo Comité de Ética em Pesquisa da Escola de Enfermagem de Ribeirăo Preto da Universidade de Sâo Paulo, em 07 de abril de 2011.

Protocolo:

$n^{\circ} 1285 / 2011$

Projeto:

- SOBRAVIVENTE DE CANCER - CONTANDO SUA HISTORIA.

Pesquisador: Ana Maria Pimenta de Carvalho

Lara de Faria Lanza

Em atendimento à Resoluçăo 196/96, deverá ser encaminhado ao CEP o relatório final da pesquisa e a publicação de seus resultados, para acompanhamento, bem como comunicada qualquer intercorrência ou a sua interrupçào.

\author{
Atenciosamente,

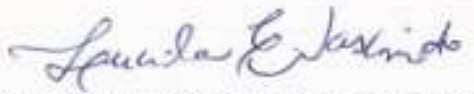 \\ Profa. Dr'. Lucila Castanheira Nascimento \\ Coordenadora do CEP-EERP/USP
}

IIma. Sra.

Prof. Dra. Ana Maria Pimenta de Carvalho

Departamento de Enfermagem Psiquiátrica e Ciências Humanas Escola de Enfermagem de Ribeirao Preto-USP 